
RESÍDUOS SÓLIDOS

Tese de Doutorado

Orientador: Prof ${ }^{\text {a }}$. Dra. Eunice Aparecida de Jesus Prudente

UNIVERSIDADE DE SÃO PAULO

FACULDADE DE DIREITO

São Paulo- SP

2018 


\title{
AS CATADORAS E OS CATADORES NA POLÍTICA NACIONAL DE RESÍDUOS SÓLIDOS
}

Tese de Doutorado apresentada à Banca Examinadora do Programa de Pós Graduação em Direito, da Faculdade de Direito da Universidade de São Paulo, como exigência parcial para obtenção do título de Doutora em Direito, na área de concentração Direitos Humanos, sob a orientação da Professora Doutora Eunice Aparecida de Jesus Prudente

\author{
UNIVERSIDADE DE SÃO PAULO \\ FACULDADE DE DIREITO \\ São Paulo-SP \\ 2018
}




\section{Catalogação da Publicação \\ Serviço de Biblioteca e Documentação \\ Faculdade de Direito da Universidade de São Paulo}

Reveilleau, Ana Célia Alves de Azevedo

As Catadoras e os Catadores na Polítca Nacional de Resíduos Sólidos / Ana

Célia Alves de Azevedo Reveilleau; orientadora Eunice Aparecida de Jesus Prudente -- São Paulo, 2018.

$285 \mathrm{p}$

Tese (Doutorado - Programa de Pós-Graduação em Direitos Humanos) Faculdade de Direito, Universidade de São Paulo, 2018.

1. Catadores. 2. Política Nacional de Resíduos Sólidos. 3. Direitos Humanos. 4. Direitos Sociais. 5. Responsabilidade. I. Prudente, Eunice Aparecida de Jesus, orient. II. Título. 
Nome: Reveilleau, Ana Célia Alves de Azevedo

Título: As Catadoras e os Catadores na Política nacional dos Resíduos Sólidos

Tese apresentada à Faculdade de Direito da Universidade de São Paulo como exigência parcial para obtenção do título de Doutora em Direito.

Aprovado em:

Banca Examinadora

Prof.Dr. Instituição:

Julgamento: Assinatura:

Prof.Dr. Instituição:

Julgamento: Assinatura:

Prof.Dr Instituição:

Julgamento: Assinatura:

Prof.Dr. Instituição:

Julgamento: Assinatura:

Prof.Dr. Instituição:

Julgamento: Assinatura: 
À memória de minha amada mãe, que partiu ainda quando este trabalho estava no seu início e em sua simplicidade me ensinou a ser uma mulher corajosa, lutadora, persistente e leal. 


\section{AGRADECIMENTOS}

Agradeço primeiramente a Deus, porque foi nele que busquei força para acreditar que mais este sonho poderia ser realizado.

Minha gratidão à Prof ${ }^{a}$. Dra. Eunice Aparecida de Jesus Prudente, minha orientadora, por me aceitar como integrante do corpo discente da Faculdade de Direito da Universidade de São Paulo e por sua acolhida durante toda a jornada transcorrida.

À Dra. Inês Virginia Prado Soares, por fazer parte de meu crescimento acadêmico, por ter aceitado fazer parte da minha banca de qualificação, que foi muito enriquecedora para a formação do presente trabalho, bem como por sua disponibilidade em me ouvir, incentivar e contribuir com indicações de livros, artigos e notícias.

À Prof ${ }^{a}$. Dra. Ana Maria Nusdeo, pelos ensinamentos que tive durante suas aulas, como aluna ouvinte, especial e regular, fazer parte de minha banca de qualificação e contribuir com seus apontamentos e indicações de bibliografia, que muito auxiliou na construção do presente trabalho.

À Prof ${ }^{a}$. Consuelo Yoshida, admirável orientadora no curso de mestrado na PUC/SP, que com seu brilhantismo e carisma muito contribui para o aperfeiçoamento dos direitos difusos e coletivos, especialmente o meio ambiente, e com quem tive o imenso prazer de trabalhar durante longos anos no Tribunal Regional Federal da $3^{\text {a }}$ Região.

Agradeço à Francisca Maria Lima, conhecida como "Chiquinha", ex-catadora do lixão Alvarenga, em São Bernardo do Campo, hoje presidente da cooperativa Reluz, na mesma cidade, por sua grande gentileza em deixar seus afazeres e compartilhar suas experiências de superação e heroísmo, que faz jus ao lema que defende as catadoras :"mulher bonita é mulher que luta" e "lugar de mulher é onde ela quiser."

Agradeço à Solange Fernandes Rezende Cabral, ex-catadora do lixão de Cotia, que tive o grande prazer de conhecer durante o $2^{\circ}$ Congresso das Catadoras, ocorrido na cidade de Campinas/SP, e com sua história comovente, me fez acreditar ainda mais que é preciso dar visibilidade para a classe de catadores, pois muitos não têm consciência de seus direitos e continuam sendo explorados.

Agradeço, a todos os meus irmãos pelo apoio, mais especialmente minha irmã Francisca, "Teca", por estar sempre ao meu lado, me ajudando, nos momentos de cansaço e pensando junto comigo. Além da minha querida cunhada Alda, por sua gentileza e auxílio.

Agradeço a todos os professores que estudei: Prof. André de Carvalho Ramos, Prof. José Mauricio Conti, Prof. Fernando Facury Scaff, Prof. Luis Fernando Massonetto, Prof ${ }^{a}$ Elsa Antonia Pereira Cunha Boiteux, Prof ${ }^{a}$ Patrícia Faga Iglecias Lemos. 
Agradeço à geógrafa, Sonia Lima, que compartilhou comigo seus conhecimentos sobre as lutas das catadoras e catadores, com seu olhar generoso e por entender tão bem a importância do trabalho realizado por estas pessoas.

Agradeço aos amigos que também cumpriam a difícil jornada de um curso de pósgraduação, Mariana Galante, Beatriz Trezzi, Cristiano Buoniconti, Allyne Andrade, todos generosos e prestativos.

Agradeço aos meus amigos de longa data que sempre me incentivaram: Meire, Nilton, Elenai, Neurivania, Selma, Lucia, Waldelice e Roberta.

Agradeço a todos os profissionais e funcionários da Universidade sempre gentis e prestativos.

Agradeço, por fim, não por serem os menos importantes, mas ao contrário por representarem tudo em minha vida, meu querido esposo, amigo e companheiro Álvaro, e minhas joias preciosas, Ana Carolina e Ana Beatriz, pela compreensão e apoio de sempre. 
"O desenvolvimento tem de estar relacionado sobretudo com a melhoria de vida que levamos e das liberdades que desfrutamos. Expandir as liberdade que temos só torna a nossa vida mais rica e mais desimpedida, mas também permite que sejamos seres sociais mais completos, pondo em prática nossas volições, interagindo com o mundo em que vivemos e influenciando esse mundo."

Amartya Sen - Desenvolvimento como liberdade 


\section{RESUMO}

ANA CÉLIA ALVES DE AZEVEDO REVEILLEAU. AS CATADORAS E OS (Doutorado) Faculdade de Direito, Universidade de São Paulo - SP, 2018

O presente estudo tem por objeto a análise dos direitos das Catadoras e dos Catadores na Política Nacional de Resíduos Sólidos (Lei n ${ }^{\circ} 12.305 / 2010$ e o Decreto Regulamentar $n^{\circ} 7.404 / 2010$ ) e das estratégias para efetivar sua emancipação econômica, fatos que passam tanto pelo cumprimento das responsabilidades dos geradores de resíduos sólidos (poder público e setor empresarial), quanto pela ampliação das lutas do Movimento dos Catadores e Catadoras de Materiais Recicláveis na conscientização de classe e política dos catadores. Para tal, o estudo inicia com a contextualização da política de resíduos, onde são traçados seus aspectos relevantes quanto aos seus objetivos, princípios, diretrizes, entraves e atuação dos administradores públicos no âmbito (nacional, estadual e municipal) no que se refere aos planos de resíduos sólidos e a inclusão da catadora e do catador. Em seguida, apresento os caminhos percorridos pela classe de catadores até o seu reconhecimento na agenda de resíduos, desde o surgimento da atividade, situação socioeconômica dos catadores, questão do gênero, relativo às mulheres e a importância da criação do Movimento Nacional dos Catadores de Materiais Recicláveis. Após, para melhor compreender os direitos alcançados pelos catadores, o estudo faz uma análise das dimensões da política de resíduos com os direitos humanos, direito ao desenvolvimento e direitos sociais, identificando que os direitos da catadora e do catador estão no âmbito dos direitos fundamentais. Partindo para o campo da efetividade dos direitos da catadora e do catador, a análise adentra nas responsabilidades dos geradores (poder público e setor empresarial) e a responsabilidade compartilhada pelo ciclo de vida do produto, com intuito de mostrar que nas obrigações dos geradores está também a inclusão dos catadores, especialmente nos sistemas de coleta seletiva e logística reversa. Por fim, apresento os mecanismos do Movimento Nacional dos Catadores e Catadoras de Materiais Recicláveis na conscientização e emancipação econômica da classe de catadores.

Palavras chaves: catadores - resíduos sólidos - direitos humanos - responsabilidade e Movimento Nacional dos Catadores de Materiais Recicláveis. 


\section{RÉSUMÉ}

ANA CÉLIA ALVES DE AZEVEDO REVEILLEAU. LES RAMASSEUSES ET LES RAMASSEURS DE DÉCHETS DANS LA POLITIQUE NATIONALE DE DÉCHETS SOLIDES, 285 f Thèse (Doctorat) Faculté de Droit, Université de São Paulo - SP, 2018

Cette étude a pour but l'analyse des droits de les Ramasseuses et du Ramasseurs de Déchets dans la Politique Nationale de Déchets Solides (Loi n ${ }^{\circ} 12$ 305/2010 et Décret Réglementaire $\mathrm{n} \circ 7$ 404/2010) et des stratégies pour réaliser leur émancipation économique, faits qui passent soit par l'accomplissement des responsabilités des producteurs de déchets solides (pouvoir publique et secteur privé), soit par l'expansion des luttes du Mouvement des Ramasseurs et des Ramasseuses de Matériaux Recyclables dans la conscientisation de classe et politique des ramasseurs de déchets. Pour le faire, l'étude débute par la contextualisation de la politique des déchets où sont traités les aspects importants de cette politique concernant ses objectifs, principes, directives, obstacles et la performance des administrateurs publics dans le champ national, étatique et municipal relativement aux plans de gestion des déchets solides et l'inclusion de la ramasseuse et du ramasseur de déchets. Ensuite, sont présentés les chemins parcourus par la classe des ramasseurs jusqu'à leur reconnaissance dans l'agenda des déchets depuis le début de l'activité, la situation socio-économique de ces personnes, la question de genre, c'est-à-dire les femmes, et l'importance de la création du Mouvement National des Ramasseurs de Matériaux Recyclables. Après, pour mieux comprendre les droits obtenus par les ramasseurs de déchets, l'étude analyse les dimensions de la politique des déchets avec les droits de l'homme, droit au développement et droits sociaux, en montrant que les droits de la ramasseuse et du ramasseur font partie des droits fondamentaux. Partant sur le terrain de l'effectivité des droits de la ramasseuse et du ramasseur de déchets, l'analyse porte sur les responsabilités des producteurs (pouvoir publique et secteur privé) et la responsabilité partagée par le cycle de vie du produit, afin de montrer que les obligations des producteurs doivent également inclure les ramasseurs de déchets, notamment dans les systèmes de collecte sélective et de logistique inverse . Pour finir, il est question des mécanismes du Mouvement National des Ramasseurs et Ramasseuses de Matériaux Recyclables dans la conscientisation et l'émancipation économique de la classe des ramasseurs de déchets.

Mots-clés: ramasseurs de déchets - déchets solides - droits de l'homme responsabilité et Mouvement National des Ramasseurs de Matériaux Recyclables. 


\begin{abstract}
ANA CÉlIA ALVES DE AZEVEDO REVEILLEAU. THE MEN AND WOMEN COLLECTORS IN THE SOLID RESIDUE NATIONAL POLITICS, $285 \mathrm{f}$ Thesis (Doctorate)), Law School, Universidade de São Paulo - SP, 2018
\end{abstract}

The current study has as object the rights analysis of the Men and Women Collectors in the Solid Residues National Politics (Law n. 12.305/2010 and the Regulative Decree n. 7.404/2010) and the strategies to actualize its economical emancipation, facts pass as much through the responsabilities execution of the solid residues generators (Public Authority and corporate sector), as for the enlargement of the Movement of Recycable Material Men and Women Collectors struggle. Therefor, the study starts with the contextualization of residues politics, where it's traced its relevant aspects as for its goals, principles, diretrixes, impediment and action of the government in extent (national, state and municipal) in relation to the solid residues plans and the inclusion of the woman and man collector. Next, I present the path covered by the collectors class until its recognition in the residues agenda, since the activity uprising, collectors' socioeconomic situation, gender matter, related to women and the importancy of the National Movement of Recycable Material Collectors criation. Afterwards, in order to better comprehend the rights achieved by the collectors, the study analyses of the politic dimensions of residues with human rights, development right and social rights, identifying that the women and men collectors' rights are in the ambit of fundamental rights. Going to the effectivity field of women and men collector rights, the analysis goes deeper into the generators' responsabilities (public authority and corporate sector) and the shared responsability for the product life, aiming to show that the generators' obligations is also the inclusion of the collectors, specially in selective collection and reversal logistic systems. Lastly, I presente the mechanisms of the National Movement of Recycable Material Men and Women Collectors in awareness and econimical emancipation of collectors class.

Key words: collectors - solid residues - human rights - responsabilities and National Movement of Recycable Material Men and Women Collectors. 


\section{LISTA DE ABREVIATURAS E SIGLAS}

AGU - Advocacia Geral da União

ANCAT - Associação dos Catadores e Catadores de Materiais Recicláveis

ABNT - Associação Brasileira de Normas Técnicas

ABRELPE - Associação Brasileira de Empresas de Limpezas Pública e Resíduos

Especiais

ACV - Avaliação do Ciclo de Vida

ANIP- Associação Nacional da Indústria de Pneumáticos

ASMARE - Associação dos Catadores de Papel, Papelão e Material Reaproveitável de Belo Horizonte

CBO - Classificação Brasileira de Ocupações

CEADEC - Centro de Estudos e Apoio ao Desenvolvimento de Emprego e Cidadania

CIISC - Comitê Interministerial Para a Inclusão Social e Econômica dos Catadores de Materiais Recicláveis

CDC - Código de Defesa do Consumidor

CONAMA - Conselho Nacional do Meio Ambiente

CORI - Comitê Orientador pra Implementação de Sistema de Logística Reversa

Decreto PNRS - Decreto Federal n ${ }^{\circ} 7.404 / 2010$

DOU - Diário Oficial da União

EMPLASA - Empresa Metropolitana de Planejamento da Grande São Paulo/SP

ES - Economia Solidaria

FAT -Fundo de Amparo ao Trabalhador

FLD - Fundação Luterana de Diaconia

GAT - Grupo Técnico de Assessoramento

GTT - Grupo de Trabalho Temático

IBAMA - Instituto Brasileiro do Meio Ambiente e dos Recursos Naturais Renováveis

IN - Instrução Normativa

inpEV - Instituto Nacional de Processamento de Embalagens Vazias 
IPEA - Instituto de Pesquisa Econômica Aplicado

j. - julgado

LD - Logística Direta

LE - Lei Estadual

LF - Lei Federal

MMA - Ministério do Meio Ambiente

MDS - Ministério do Desenvolvimento Social e Combate à Fome

MNCR - Movimento Nacional dos Catadores de Material Reciclável

MTE - Ministério do Trabalho e Emprego

OAF - Organizações de Auxílio Fraterno

OIT - Organização Internacional do Trabalho

ONU - Organização das Nações Unidas

ONGs - Organizações Não Governamentais

PIDESC - Pacto Internacional de Direitos Econômica Sociais e Culturais

PMGIRS - Plano Municipal de Gestão Integrada de Resíduos Sólidos

PNMA - Política Nacional de Meio Ambiente ( Lei Federal n. 6.938/1981)

PNRS - Política Nacional de Resíduos Sólidos (Lei Federal n. 12.305/2010)

PNSB - Política Nacional de Saneamento Básico (Lei Federal n 11.445/2007)

PSA - Pagamento por Serviços Ambientais

RCCVP - Responsabilidade Compartilhada pelo Ciclo de Vida do Produto

Res. - Resolução

RSU - Resíduo Sólido Urbano

SELUR - Sindicato das Empresas de Limpeza Urbana do Estado de São Paulo

SEMUC - Secretaria Estadual de Mulheres Catadoras

SENAES - Secretaria de Economia Solidária

SINIR - Sistema Nacional de Informações sobre a Gestão dos Resíduos Sólidos

SISNAMA - Sistema Nacional do Meio Ambiente 
SNVS - Sistema Nacional de Vigilância Sanitária

STJ - Superior Tribunal de Justiça

SUASA - Sistema Unificado de Atenção à Sanidade Agropecuária

TCU - Tribunal de Contas da União

TJSP - Tribunal de Justiça do Estado do São Paulo 


\section{SUMÁRIO}

INTRODUÇ̃̃̃O

17

CAPÍTULO 1 CONTEXTUALIZAÇÃO DA POLÍTICA NACIONAL DE RESÍDUOS
SÓLIDOS

1.1 Política Nacional de Resíduos Sólidos: Princípios, objetivos e diretrizes 23

1.2 Política Nacional de Resíduos Sólidos e seus entraves 35

1.3 Noções sobre o Federalismo brasileiro e as políticas públicas $\quad 40$

1.3.1 Os Entes Federativos na atuação da Política Nacional dos Resíduos Sólidos $\quad 44$

1.3.2 Dos Planos e Gerenciamento dos Resíduos Sólidos na Política Nacional de Resíduos

Sólidos e a Inclusão da Catadora e Catador 45

1.3.2.1 Planos de Resíduos Sólidos 45

1.3.2.2 Plano Nacional de Resíduos Sólidos e suas Perspectivas para Inserção da Catadora e do Catador

1.3.2.3 Planos Estaduais de Resíduos Sólidos e suas Perspectivas para Catadora e o Catador

1.3.2.4 Plano Estadual de Resíduos Sólidos do Estado de São Paulo 52

1.3.2.5 Planos Municipais de Resíduos Sólidos 53

1.3.2.5.1 Plano de Resíduos Sólidos do Município de São Paulo 56

1.3.3. Planos de Gerenciamento de Resíduos Sólidos

CAPÍTULO 2 AS CATADORAS E OS CATADORES NA POLÍTICA NACIONAL DOS RESÍDUOS SÓLIDOS 61

2.1 Da invisibilidade da atividade de Catador ao reconhecimento jurídico 61

2.2 Da situação social das Catadoras e Catadores $\quad 64$

2.3 Do Movimento Nacional dos Catadores de Recicláveis 67

2.4 Gênero: Catadoras de Materiais Reutilizáveis e Recicláveis 72

2.4.1 Caso Francisca Maria Lima (ex-catadora do Lixão Alvarenga à Líder de Cooperativa)

2.4.2 Caso: Solange Fernandes Rezende Cabral (ex-moradora do lixão da Cidade de CotiaSP)

2.5 Do Reconhecimento dos Catadores na Agenda da Política Nacional de Resíduos Sólidos 
CAPÍTUlo 3 POLÍTICA NACIONAL DE RESÍDUOS SÓlidos E SUAS DIMENSÕES NOS DIREITOS HUMANOS, DIREITO AO DESENVOLVIMENTO E DIREITOS SOCIAIS DOS CATADORES

3.1 A Política Nacional dos Resíduos Sólidos frente aos direitos humanos

3.2 A Política Nacional dos Resíduos Sólidos e o Direito ao Desenvolvimento

3.3 Direitos Econômicos, Sociais e Culturais e Política Nacional dos Resíduos Sólidos

100

3.4 Dos Diretos Sociais da Catadora e do Catador: na Política Nacional dos Resíduos Sólidos

CAPÍTULO 4 RESPONSABILIDADE DO PODER PÚBLICO E SETOR EMPRESARIAL NA GESTÃO DOS RESÍDUOS SÓLIDOS E NA INCLUSAO DA CATADORA E DO CATADOR 119

4.1 Das Responsabilidades dos Geradores na Política Nacional dos Resíduos Sólidos 119

4.2 Da Responsabilidade do Poder Público e Setor Empresarial no âmbito da Gestão Compartilhada dos Resíduos Sólidos

4.3 Responsabilidade Compartilhada pelo Ciclo de Vida do Produto e a Inclusão da Catadora e do Catador

4.3.1 Participação da Catadora e Catador: Reciclagem, Coleta Seletiva e Logística Reversa

4.3.1.1 Da importância da Reciclagem

4.3.1.2. Reciclagem: Entraves e Perspectivas para Inclusão da Catadora e Catador

4.3.2. Da Importância da Coleta Seletiva

4.3.2.1 Coleta Seletiva: Entraves e Perspectivas para Inclusão da Catadora e do Catador 137

4.3.3 Importância da Logística Reversa

4.3.3.1 Logística Reversa: Entraves e Perspectivas para Inclusão da Catadora e Catador 145

4.3.3.2 Obrigados a Estruturar a Logística Reversa

4.3.3.3 Logística Reversa e os Acordos Setoriais e os Resíduos Perigosos: Agrotóxicos; Óleos

Lubrificantes, Lâmpadas, Eletroeletrônicos, Medicamentos e Pneus

4.3.3.4 Acordo Setorial de Embalagens e Geral e Inclusão da Catadora e Catador 


\section{AS CATADORA E CATADORES: PERSPECTIVAS DA EMANCIPAÇÃO ECONÔMICA E EMPREENDORISMO}

5.1 Do Surgimento das Cooperativas de Catadores 161

5.2 Realidade Socioeconômica do Associativismo ou Cooperativismo 165

5.3 Da Formação das Cooperativas de Catadores 167

5.4 O Cooperativismo e as perspectivas para e a Catadora e o Catador $\quad 171$

5.5 Catadora e o Catador: Como sujeitos de Pressão para implementação da Política Nacional de Resíduos $\quad 173$

5.5.1 Região Centro Oeste 176

5.5.2 Região Sul 176

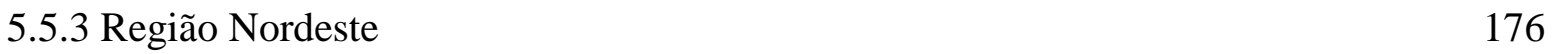

5.5.4 Região Sudeste 177

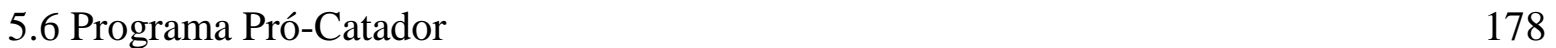

5. 7 Programa CATAFORTE 181

5.8 Pagamento por Serviços Ambientais 184

5.8.1 Pagamento por Serviços Ambientais: Caso de Minas Gerais 186

5. 9 Catadoras e o Catadores: Avanço do Protagonismo e Empreendedorismo em Redes de $\begin{array}{ll}\text { Cooperativas } & 188\end{array}$

5.9.1Rede ANASTÁCIA 188

5.9.2 Rede CATA BAHIA METROPOLITANA - VERDECOOP 189

5.9.3 Rede CATA PB 190

5.9.4 Rede CATAPARANÁ - PR 191

5.9.5 Rede MS - MS 192

$\begin{array}{ll}\text { CONCLUSÃO } & 195\end{array}$

$\begin{array}{ll}\text { BIBLIOGRAFIA } & 205\end{array}$

$\begin{array}{ll}\text { ANEXOS } & 221\end{array}$

Lei n.12.305, de 02 de Agosto de 2010 - Política Nacional de Resíduos Sólidos 221

Decreto n. 7.404, de 23 de dezembro de 2010 - Regulamenta a Política Nacional de Resíduos $\begin{array}{ll}\text { Sólidos } & 247\end{array}$

Decreto n. 7.405, de 23 de dezembro de 2010 - Institui o Programa Pró-Catador 276 
Lei n. 12.690, de 19 de julho de 2012 - Dispõe sobre a organização e o funcionamento das Cooperativas de Trabalho 


\section{INTRODUÇÃO}

O tema relacionado aos resíduos sólidos não é assunto novo em minhas pesquisas, pois já foi objeto de dissertação de mestrado, na qual tive a oportunidade de analisá-lo numa abordagem voltada para a gestão compartilhada dos atores sociais (poder público, setor empresarial e coletividade). Embora, somente estivesse em discussão, à época, o Projeto de Lei da Política Nacional de Resíduos Sólidos, já era possível perceber a importância dessa norma para a sociedade, nos seus mais variados aspectos, quais sejam, ambiental, econômico, sanitário e social.

Diante da grandiosidade e das múltiplas variáveis em que se entrelaçam o tema, e que se intensificaram com a promulgação da norma nacional de resíduos sólidos, que trouxe definições próprias para a implementação da gestão e gerenciamento dos resíduos sólidos baseado num desenho institucional, com princípios, objetivos, diretrizes e responsabilidades para os todos os entes políticos, empresários e sociedade, nova inspiração me lançou a aprofundar o assunto, pelo enfoque dos direitos humanos, notadamente no que se refere à Catadora e ao Catador na Política Nacional de Resíduos Sólidos. Com suas habilidades, eles cumprem a difícil tarefa de promover a ressignificação dos resíduos sólidos ao possibilitarem seu retorno à cadeia de produção, evitando que novos insumos naturais sejam utilizados.

Trata-se de uma política que dialoga com os direitos fundamentais previstos na Constituição Federal de erradicar a pobreza e a marginalização e de reduzir as desigualdades sociais (artigo $3^{\circ}$, III, 'a', CF); redução das desigualdades regionais e sociais, busca do pleno emprego, defesa do meio ambiente, inclusive mediante tratamento diferenciado conforme o impacto ambiental dos produtos e serviços e de seus processos de elaboração e prestação (art. 170, VI, CF), defesa e proteção do meio ambiente (art. 225, da $\mathrm{CF})$.

Também pode ser lançado um olhar para a PNRS e identificar sua relação, com os direitos humanos, direito ao desenvolvimento e direitos sociais, por estar voltada a construir um desenvolvimento que leve em conta não apenas o aspecto econômico, mas a sustentabilidade em amplo sentido, de proteção ao meio ambiente e emancipação econômica dos catadores. 
Contudo, passados mais de sete anos da promulgação da PNRS, muitas dificuldades não foram superadas como, por exemplo: existência de muitos lixões, não elaboração de forma definitiva do Plano Nacional de Resíduos, a maioria dos estados e municípios também não elaboraram seus planos de resíduos sólidos, os quais são importantes instrumentos da PNRS, pois traçam os diagnósticos, metas e formas de execução para gestão adequada dos resíduos sólidos de acordo com cada localidade.

Além disso, há precariedade de investimentos em programas de reciclagem e coleta seletiva e sistema de logística reversa, considerados instrumentos de ação para a implementação da gestão compartilhada do ciclo de vida dos produtos.

Embora, a PNRS tenha instituído instrumentos econômicos voltados para atender iniciativas, com caráter preventivo e redução da geração de resíduos sólidos nos processos produtivos; desenvolvimento de produtos com menores impactos na saúde humana e à qualidade ambiental em seu ciclo de vida; desenvolvimento de pesquisas voltadas para tecnologias limpas, etc., não avançaram as ações para cumprimento da PNRS.

Todas estas dificuldades impedem e retardam o cumprimento da gestão adequada dos resíduos sólidos, bem como deixam de atender a dimensão social prevista na PNRS, relativa à integração de cooperativas ou associações de catadores de materiais recicláveis na gestão integrada dos resíduos sólidos, nos objetivos, insculpidos no art. $7^{\circ}$, inc. XII, da PNRS, ${ }^{1}$ onde a Catadora e o Catador são reconhecidos como protagonistas da gestão de resíduos sólidos. Protagonista, conforme o dicionário Aurélio, quer dizer "ator principal, pessoa que ocupa o primeiro lugar em qualquer acontecimento, promotor; interveniente

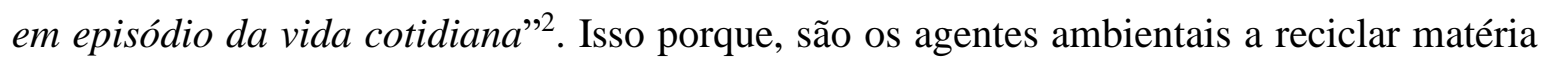
prima, considerada pela sociedade como "lixo".

Percebe-se aí, uma dura contradição entre a previsão da norma e a realidade fática no que concerne à implementação da gestão dos resíduos sólidos e a realidade enfrentada pela catadora e pelo catador, pois muitos continuam na informalidade, sem direitos e benefícios trabalhistas, expostos a riscos de toda ordem pelas ruas e marginalizados.

\footnotetext{
${ }^{1}$ Art. $7^{\circ}$, XII, da PNRS: "integração dos catadores de materiais reutilizáveis e recicláveis nas ações que envolvam a responsabilidade compartilhada pelo ciclo de vida dos produtos".

${ }^{2}$ https://dicionariodoaurelio.com/protagonista, acessado em 28/10/2017.
} 
Nesse contexto, e sob enfoque dos Direitos Humanos, a presente tese pretende analisar os direitos alcançados pela Catadora e o Catador na Política Nacional de Resíduos Sólidos e quais as estratégias para efetivar sua emancipação econômica.

No campo das estratégias para a emancipação econômica dos catadores envolve tanto a obrigação do poder público e setor empresarial nas ações para implementar a responsabilidade compartilhada do ciclo de vida dos produtos e integrar catadores, quanto o avanço da conscientização de classe e política da catadora e do catador.

O estudo terá início com a contextualização da PNRS, fazendo um panorama sobre seus objetivos, princípios e diretrizes, abordando os desafios e problemáticas que envolvem sua implementação, os quais darão suporte para adentrar na atuação dos entes federativos, sobretudo no que se refere à cooperação para o desenvolvimento de políticas públicas, dentre elas a de resíduos sólidos. Finaliza o capítulo com análise dos conteúdos dos planos de resíduos sólidos (nacional, estadual, e municipal) e do plano de gerenciamento, identificando seus aspectos legais, e como foram contemplados a categoria de catadores, nas versões preliminares dos Planos Nacional e nos Planos Estadual e Municipal, (São Paulo/SP), abordando as proposições que serão realizadas em prol da catadora e do catador.

Toda essa contextualização pretende realçar desde o início que a PNRS transpõe a chamada "inclusão social", para reconhecer a Catadora e o Catador como seus verdadeiros protagonistas, como já adiantado.

No segundo capítulo, serão traçados os liames do reconhecimento jurídico da atividade de catação, além de abordar a questão do gênero na categoria dos catadores, destacando o papel das mulheres, tendo em vista que se percebeu o papel de destaque exercido por elas na atividade de catação, na execução do trabalho, nas lideranças de cooperativas e à frente de movimentos sociais na reivindicação por seus direitos. Ademais, a própria classe assim se identifica.

Também serão destacados a evolução e avanços do Movimento Nacional dos Catadores de Materiais Recicláveis, sobretudo da importância do seu papel na inclusão da classe de catadores na agenda pública dos resíduos sólidos.

Toda essa abordagem servirá para conhecer a luta dos movimentos sociais no processo de estruturação e efetivação das políticas públicas, bem como para demonstrar 
que a inclusão dos catadores não decorreu apenas da promulgação da PNRS, mas da mobilização de seus atores, e que a categoria já atuava antes, sendo a política, a bem da verdade, um merecido reconhecimento do seu protagonismo.

No terceiro capítulo, o estudo da PNRS e suas dimensões com os Direitos Humanos, Direitos ao Desenvolvimento e Direitos Sociais, por estar sistematizada em modelo de desenvolvimento, voltado à sustentabilidade econômica, ambiental e social.

Com isso, entende-se que a Catadora e o Catador, mais do que a inclusão social, os direitos previstos na PNRS, e se tratam de direitos fundamentais, e por estarem expressos em política pública, podem ser, inclusive, objeto de controle judicial.

No quarto capítulo adentra-se no tema das responsabilidades dos geradores, a responsabilidade compartilhada pelo ciclo de vida do produto e os respectivos instrumentos que servem de implementação à gestão adequada dos resíduos sólidos e à integração da catadora e do catador, em que se destaca a reciclagem, a coleta seletiva e logística reversa, seus entraves e perspectivas.

Toda esta análise permitirá verificar que a PNRS pouco avançou no campo prático, decorrendo o abismo que há entre os direitos garantidos pela norma e a situação de fato vivenciada pelos catadores. Além do liame que há entre a responsabilidade quanto à adequada disposição dos resíduos e a responsabilidade da inclusão das cooperativas de catadores de materiais recicláveis.

Por fim, no quinto e último capítulo, a abordagem será especifica quanto à mobilização do Movimento Nacional dos Catadores e Catadoras de Materiais Recicláveis, bem como o trabalho realizado de forma organizada, em cooperativas ou rede de cooperativas, além dos programas e incentivos que estão sendo fomentados e contribuindo para que tenham autonomia.

Apresentam-se casos práticos, que permitem identificar que a catadora e catador são de fato os protagonistas da política pública, além de focar na capacidade de empreendedorismo, por meio de programas e projetos financiados por órgãos públicos e privados.

\section{Considerações Metodológicas}


Neste tópico, pretende-se expor os caminhos que foram percorridos para as análises e os procedimentos de investigação desenvolvidos nesta Tese.

O objetivo deste trabalho é compreender no âmbito na política nacional de resíduos sólidos o enquadramento dos direitos da classe de catadores de materiais recicláveis e quais estratégias mostram-se necessárias para construção da emancipação econômica de prevista no âmbito da política de resíduos para os catadores. Isso porque, no campo prático grande parte das catadoras e catadores estão na informalidade e excluído no mercado de trabalho, permanecendo na dependência da implementação das ações do poder público e setor empresarial.

A partir dessa situação, houve a provocação para algumas indagações: Que direitos foram alcançados pela classe de catadores na PNRS? Que responsabilidades têm o poder público e setor empresarial quanto à emancipação econômica da catadora e do catador? Como a catadora e o catador poderão ultrapassar as barreiras da exclusão?

Assim, o presente trabalho visa avançar na compreensão dos direitos consagrados pela catadora e pelo catador na política de resíduos e quais mecanismos possibilitam sua emancipação econômica.

A metodologia utilizada para atender a presente proposta tem o viés qualitativo, fundamentado no método dedutivo, construído por pesquisa bibliográfica, visitas as cooperativas, entrevistas, participação no II Congresso Estadual de Mulheres Catadoras de Materiais Recicláveis, palestras no Programa Cata-Forte III, etc.

A pesquisa bibliográfica realizada compreende produções sobre o tema de estudo, como: livros, revistas, dissertações de mestrado e tese de doutorado, boletins e estudo das normas que envolvem os catadores.

Os locais e bases de dados foram: biblioteca da Universidade de São Paulo, (USP), por meio o sistema Dedallus e Sistema Integrado de Biblioteca da Universidade de São Paulo (SIBiUSP), biblioteca da Universidade de Jean Moulin (França), biblioteca da Emplasa e busca livre no google.

A partir dos assuntos consultados remeteram-se a outras bases das seguintes instituições: Supremo Tribunal Federal, Superior Tribunal de Justiça, Tribunal Estaduais, Movimento Nacional dos Catadores de Materiais Recicláveis - MNCR e Movimento 
Nacional de Catadores e Catadores de Materiais Recicláveis - ANCAT, Associação Brasileira de Empresas de Limpezas Pública e Resíduos Especiais - Abrelpe, - Instituto de Pesquisa Econômica Aplicado - Ipea, etc.

Assim, a introdução e estas considerações metodológicas têm o intuito de esclarecer o tema da tese, seus objetivos e sua metodologia. 


\section{CONCLUSÃO}

A partir de uma visão dos direitos humanos o presente trabalho fez uma análise da Catadora e do Catador na Política Nacional dos Resíduos Sólidos, objetivando fazer um enquadramento jurídico dos direitos alcançados por eles na norma federal.

Objetivou-se também identificar que para real efetivação de sua emancipação econômica é necessário passar pelo cumprimento das responsabilidades dos geradores de resíduos sólidos (poder público e setor empresarial) e a ampliação das lutas do Movimento dos Catadores e Catadoras de Materiais Recicláveis na conscientização de classe e política dos catadores.

Assim, as conclusões estão sintetizadas em três partes: a primeira no âmbito do conhecimento da política de resíduos sólidos e sua relação com a catadora e os catadores; a segunda, no enquadramento dos direitos alcançados pela catadora e o catador na política de resíduos e a terceira, refere-se às estratégias para a efetivação da emancipação econômica dos catadores.

Assim, a primeira parte destas conclusões refere-se aos capítulos primeiro e segundo, os quais estão centrados nos principais aspectos da Política Nacional de Resíduos Sólidos e conhecimento da classe de catadores.

No capítulo primeiro, houve a contextualização da PNRS a partir de seu desenho institucional, com descrição dos seus objetivos, princípios e diretrizes, além da análise dos entraves para a implementação da PNRS. Por fim, foram traçados o perfil dos entes políticos no campo das competências e cooperação diante das políticas pública, em especial da política de resíduos e os planos de gestão resíduos sólidos no âmbito nacional, estadual e federal.

Toda a contextualização permitiu extrair o seguinte:

No desenho institucional da PNRS é possível perceber que se busca implantar uma nova dinâmica de desenvolvimento, conduzida por uma ordem de prioridade de não gerar, reduzir e reciclar, guiada por importantes princípios, como desenvolvimento sustentável, precaução e prevenção, poluidor-pagador, participação social, bem como princípios 
específicos, dentre eles visão sistêmica dos resíduos que considere as variáveis ambiental, econômica, tecnológica, social e saúde pública e reconhecer os resíduos como bem econômico promovedor de renda e cidadania.

Assim, os objetivos, princípios e diretrizes, previstos na PNRS conduzem a uma nova postura de padrões de produção e consumo, utilização razoável dos recursos naturais, incentivos, conscientização da coletividade, cooperação entre e setor público e privado e imposição de responsabilidades a todos geradores pelo ciclo de vida dos produtos.

A grande geração de resíduos demonstra que poucos foram os avanços na gestão e gerenciamento dos resíduos sólidos. Isso porque, muitas cidades brasileiras não conseguiram erradicar seus lixões e a inexistência do plano nacional de gestão dos resíduos sólidos corroborou para isso. Menos da metade dos estados realizaram seus planos de gestão integrada dos resíduos e ainda há muitos municípios sem planos de gestão de resíduos, aliados à implantação parcial do SINIR e falta de recursos específicos.

Tais dificuldades existentes permitem concluir pela necessidade de investimentos e recursos específicos na construção de infraestrutura, como aterros sanitários, usinas de compostagem, estações de transbordos, programas de coleta seletiva e implantação dos sistemas de logística reversa, a utilização pelos de consórcios entre os município, a conscientização da população, sem descuidar de dar oportunidade para a participação da sociedade.

No tocante a atuação dos entes políticos na realização das políticas de resíduos a cooperação é um traço marcante para viabilizar sua implementação, exigindo papel ativo dos municípios, dos Estados e da União, especialmente no âmbito técnico e financeiro.

Por fim, no primeiro capítulo, no estudo da elaboração dos planos de gestão e gerenciamento de resíduos sólidos pelos entes federativos e setor privado, que são instrumentos essenciais para dar efetividade à política de resíduos sólidos e identificar para a catadora e o catador que a chamada "inclusão social" carrega uma valorização de direitos para que integrem à gestão dos resíduos em todas as cidades brasileiras.

No segundo capítulo, a análise foi sobre a classe de catadores. Ela percorreu sua trajetória histórica, a partir do surgimento da atividade até o reconhecimento nas normas 
jurídicas e na agenda dos resíduos sólidos, as quais permitem tecer as seguintes conclusões:

Trata-se de uma classe em situação socioeconômica muita diversificada, alguns têm residência fixa, trabalham em cooperativas ou associações, outros vivem nas ruas ou em locais precários; lixões ou aterros e os estudos são imprecisos quanto ao número de catadores existentes.

Além disso, reconheceu-se a importância do gênero feminino, que estão mobilizadas com o Movimento Nacional dos Catadores de Materiais Recicláveis, mas com um viés específico para o empoderamento das mulheres nas bases, nas suas regiões e no movimento social. Elas somam a maioria na execução do trabalho, nas lideranças de cooperativas, na promoção de encontros, congresso, seminários, com formação de uma Secretaria Estadual de Mulheres Catadoras - SEMUC, cujo objetivo é promover a igualdade entre os homens e mulheres na categoria e combater todas as formas de preconceito e discriminação.

Por sua vez, a criação, em 2001, do Movimento Nacional dos Catadores de Materiais Recicláveis para representar a classe de catadores foi um salto para que os catadores pudessem ter visibilidade na sociedade, a partir de congressos, encontros, marchas, seminários, além do apoio de instituições, professores, pressão social e negociação política com as diversas esferas da administração pública, o que permitiu que alcançassem o "status" de um problema político e serem inseridos na agenda pública dos sólidos, buscando-se soluções para sua condição.

Assim, no estudo da Catadora e Catador na Política de Resíduos Sólidos restou assentado que se trata de uma classe que se identifica pelo gênero, e que apesar das muitas dificuldades, estão construindo a própria inclusão, evidenciado pelos direitos previstos PNRS, norma jurídica de maior expressão para a categoria.

A segunda parte dessas conclusões refere-se ao capítulo terceiro, dedicado ao enquadramento ou natureza dos direitos alcançados pela catadora e o catador na política de resíduos sólidos. Nesse capítulo, a análise parte da relação da Política Nacional dos Resíduos Sólidos e suas dimensões com os direitos humanos, direito ao desenvolvimento e direitos sociais, com as seguintes conclusões: 
O enfoque da política de resíduos com os direitos humanos decorre das dimensões que ele atinge, como econômica, proteção ambiental, cultural, social, esta especialmente dirigida à classe de catadores que encontraram no manuseio do lixo prover a própria sobrevivência e de sua família.

A política de resíduos tem dentre suas proposições viabilizar a emancipação econômica dos catadores, numa menção clara à valorização da condição humana. Desse modo, os direitos alcançados pela Catadora e o Catador na PNRS representam direitos humanos. Do mesmo modo, tem relação com direito ao desenvolvimento, pois visa proporcionar o desenvolvimento centrado no ser humano para que a classe de catadores tenha uma vida mais digna.

Compreende-se que os direitos alcançados pela Catadora e Catador na PNRS são direitos subjetivos vinculados aos direitos sociais, pois representam a oportunidade de trabalho e obtenção de renda para manutenção de moradia, alimentação, lazer, educação, cultura, enfim ter sua liberdade plena. A efetivação dos direitos sociais decorre do princípio da dignidade da pessoa humana, obrigando o Estado respeito a realizar uma prestação mínima, este entendido como poder usufruir de uma vida digna, com autonomia, enquanto cidadão.

Para garantia da tutela desse mínimo existencial cabe o manejo de ações judiciais, como a ação civil pública, com a finalidade efetivar os direitos fundamentais, inclusive afastando a "reserva do possível", que só pode ser acatada contanto seja devidamente demonstrada a insuficiência de recursos pelo poder público.

As políticas públicas são normas programas e no bojo delas são traçados os compromissos assumidos pelo poder público, que podem ser suscetíveis de controle judicial, sem afronta à separação dos poderes. É que cabe ao Poder Judiciário controlar a atividade administrativa, isso faz parte do Estado-Democrático de Direito, cumprindo seu dever de tutelar a atuação irregular da administração pública.

Conclui-se que catadora e o catador alcançaram na PNRS direitos subjetivos, que podem deles se valer para pressionar o efetivo cumprimento da política, que se estende no interesse jurídico, para buscar uma prestação jurisdicional, por intermédio do Movimento Nacional dos Catadores de Materiais Recicláveis - MNCR, requerendo que o poder público cumpra obrigação de fazer consubstanciada na elaboração do Plano de Gestão de 
Resíduos Sólidos, com a integração das cooperativas ou associações de catadoras e catadores e os catadores autônomos.

A terceira e última parte da presente conclusão refere-se aos capítulos quarto e quinto, que discutem as estratégias para dar efetividade a emancipação econômica dos catadores e catadoras, as quais estão relacionados ao âmbito da responsabilidade dos geradores de resíduos sólidos (poder público e setor empresarial) e a ampliação da luta do Movimento dos Catadores e Catadores de Materiais Recicláveis.

No capítulo quarto buscou-se relacionar as responsabilidades dos geradores nas ações de responsabilidade compartilhada (poder público e setor empresarial) com a integração das catadoras e catadores, especialmente nos instrumentos coleta seletiva e logística reversa, que resultaram nas seguintes conclusões:

Os responsáveis pelos resíduos sólidos produzidos devem arcar com os custos inerentes à sua gestão, cujo fundamento está no princípio do poluidor-pagador, inclusive tomando medidas reparatórias e preventivas ou mitigadoras para compensar eventuais danos.

Na responsabilidade compartilhada durante todo o ciclo de vida de um produto, há obrigações para os geradores, desde o desenvolvimento do produto até a disposição final, tratando-se de uma obrigação complexa, exigindo deveres dos múltiplos atores envolvidos, com ações encadeadas. Isto é, cada etapa depende da anterior, para que o produto venha completar seu ciclo.

Trata-se de uma responsabilidade que se irradia para além das etapas produtivas (fabricação e importação) e fornecimento (distribuição e comercialização) de produtos para alcançar a fase chamada de pós-consumo. As responsabilidades assumidas pelo titular de serviço público de limpeza urbana e de manejo de resíduos sólidos, que seja dos fabricantes, importadores, distribuidores e comerciantes deverá ser previamente ajustada a forma de remuneração para o setor público.

A PNRS garantiu a catadora e ao catador integrarem as atividades que envolvam a responsabilidade compartilhada pelo ciclo de vida dos produtos, conforme os dispositivos legais a seguir listados, artigo $7^{\circ}$, inciso XII, art. $8^{\circ}$, incisos III e IV, art. $36, \S^{\circ}$, todos da 
Deliberação $\mathrm{n}^{\circ} 11 / 2017$ do Comitê Orientador para Implementação de Sistema de Logística.

Restou assentado ainda que a obrigação de integrar os catadores, cooperativas ou associação de catadores de materiais recicláveis nas ações de responsabilidade compartilhada decorre do cumprimento dos deveres legais, previsto na PNRS. Ela não se confunde com a responsabilidade em sentido jurídico, baseada na ideia de reparação de dano, de um vínculo jurídico entre credor e devedor, no qual o primeiro tem direito de exigir do segundo o cumprimento de determinada prestação. De igual modo, não se confunde com o termo responsabilidade civil, que são as medidas para reparação de danos.

Assim, a efetividade dos direitos e emancipação econômica da catadora e do catador previstos na PNRS passa pelo campo da responsabilidade do poder público e do setor empresarial que devem atuar no cumprimento de suas obrigações, visto que há um liame entre as obrigações dos geradores e os direitos de inserção dos catadores. Isso porque, se no sistema da PNRS, todos os geradores, poder público e setor empresarial devem promover a gestão de resíduos sólidos, que por sua vez são implementados pelos instrumentos, como a reciclagem, coleta seletiva e logísticas reversas, e considerando que a norma jurídica objetiva a integração dos catadores de materiais reutilizáveis e recicláveis, todos os geradores têm obrigação de implementar os instrumentos da responsabilidade compartilhada, com participação da catadora e do catador.

O Movimento Nacional dos Catadores propõe adoção da reciclagem popular para reverter a situação de exploração, pois entende ser inclusiva, com a participação de todos, catadores, governos, empresa e população.

A reciclagem deve ser pensada como uma política pública, levando em conta as especificidades de cada localidade para poder incluir o maior número de catadoras e catadores, ampliar as parcerias com instituições públicas e privadas, incentivos e desenvolvimento de redes de cooperativas, capacitação técnicas e em gestão para catadoras e catadores e sensibilização da população para correta separação dos resíduos, etc.

As redes de cooperativas são consideradas como um dos caminhos para a inclusão da catadora e catador a disputar o mercado de reciclagem, por proporcionar melhores oportunidades de ganhos e independência dos poderes públicos e setor empresarial e a emancipação econômica. 
Foi assinado o Acordo Setorial para Implantação do Sistema de Logística Reversa de Embalagens em Geral no dia 25/11/2015, visando a inserção dos catadores. Contudo, devido as diversas controvérsias envolvendo os termos do acordo foi proposta, em julho de 2016, uma Ação Civil Pública (proc. nº 0015159-35.2016.4.03.6100), em trâmite junto a $17^{\mathrm{a}}$ Vara Federal de São Paulo, pelo Ministério Público de São Paulo e Ministério Público Federal.

A demanda objetiva requerer dentre outras providências, sejam estabelecidas de forma clara as responsabilidades de todos os acordantes; sejam fixadas a forma de monitoramento e cumprimento das metas e indicadores; a explicitação das regras econômico-financeiras que fundamentam a existência do próprio acordo setorial, além de excluir de seus termos as obrigações econômicas imputadas às cooperativas de catadores. Também são questionadas as razões da não previsão de remuneração direta pelos serviços de logística reversa prestado pelos catadores.

A inserção da catadora e catador no sistema de logística reversa nos resíduos perigosos, embora, sejam poucas iniciativas no setor de eletroeletrônicos, demonstram que há oportunidade para os catadores integrarem esse segmento, dependendo de capacitação e treinamento específicos para o manuseio de tais resíduos.

A PNRS, por si só, não foi suficiente para integrar a catadora e o catador, o que só será alcançado com amplo processo de fiscalização, com imposição de medidas que obriguem o setor público e o privado ao cumprimento de suas obrigações de fazer quanto à destinação adequada dos seus resíduos sólidos e rejeitos, aliada à obrigação social de integrarem as cooperativas ou associações e catadores individuais.

Os poderes públicos devem ter dotação orçamentária específica para realizar programas de coleta seletiva e reciclagem, devem propor medidas de incentivos para os sistemas de logística reversa, pois, mais do que instrumentos de implementação de responsabilidade compartilhada do ciclo de vida dos produtos, são instrumentos que geram empregos, renda e cidadania.

Por fim, no capítulo quinto tratou-se do trabalho organizado dos catadores em cooperativas, programas e incentivos em prol da classe de catadores, com exemplos de redes de cooperativas buscando relacionar que para emancipação econômica da classe de 
catadores passa pelo campo da ampliação da luta do Movimento Nacional da Catadora e Catador, na conscientização de classe e política, com as seguintes conclusões:

A Associação Nacional dos Catadores e Catadoras de Materiais Recicláveis ANCAT, fundada em 04/01/2000, exerce um papel fundamental para que a PNRS seja implementada e sejam efetivados os direitos nela previsto para a catadora e o catador, a exemplos de algumas conquistas que se fizeram o âmbito federal como a criação do Comitê Interministerial para Inclusão Social e Economia dos Catadores de Materiais Reutilizáveis - CIISC (2003), a instituição do Programa Pró-Catador e dos Projetos CATAFORTE I, II e III, atualmente em vigor, que tem como fundamento a capacitação técnica dos catadores e catadoras visando o conhecimento sobre o mercado da reciclagem.

A ANCAT está voltada ao apoio organizacional, social e econômico dos catadores de materiais recicláveis e organizações, bem como está articulada com os catadores da América Latina, decorrendo a formação de parceria com órgãos internacionais, levando o Brasil a ser pioneiro em ações de organização dos catadores. Ela é formada exclusivamente, por determinação estatutária, por Catadores de Materiais Recicláveis.

O objetivo da ANCAT é contribuir com trabalhadores organizados em cooperativas e associações e também com os catadores que trabalham nas ruas e em lixões em todo território nacional, apoiar o MNCR na execução de diversos projetos e promover atividade de mobilização e encontros entre os catadores e catadoras em todo o Brasil, nos seguintes segmentos: promoção social, geração de trabalho e renda educação popular, capacitação profissional, meio ambiente e direitos humanos, apoiando políticas públicas de fomento à economia solidária, a fim de fortalecer as cooperativa

Para a efetividade dos direitos dos catadores e sua emancipação econômica é necessário ampliar a luta e fortalecer o Movimento Nacional do Catador e da Catadora, além da conscientização de classe e política, para que se amplie o número de catadores que usufruem realmente de seus direitos, uma vez que muitos ainda continuam em situação de vulnerabilidade, nas ruas e lixões.

Nos exemplos dados, as redes de cooperativas assinaram consórcios, contratos de parceria, participaram de congressos, seminários, encontros e mostraram que os catadores, por meios de seus movimentos, estão possibilitando que a política seja concretizada, com a inclusão da categoria como um todo. Contudo, persistem os desafios diante da 
complexidade do mercado de reciclagem e das décadas consecutivas de pura exploração. Assim, a elaboração de estratégias para romper o ciclo de exploração é indispensável.

Desse modo, ao longo deste trabalho procurou-se discutir e demonstrar que a catadora e catador são portadores de direitos fundamentais e que, apesar das dificuldades, estão, por meio do Movimento Nacional de Catadoras e Catadores, pressionando seja efetivamente implementada a Política Nacional de Resíduos Sólidos, onde figuram como protagonistas. Eles constroem, dessa maneira, sua emancipação. 


\section{BIBLIOGRAFIA}

\section{ADVOGACIA GERAL DA UNIÃO - AGU - Guia de Licitações Sustentáveis.}

Disponível em http://www.agu.gov.br/page/content/detail/id_conteudo/138067; acessado em 14/05/2017

AITH, Fernando Mussa Abujamra, "Políticas Pública de Estado e de governo: instrumentos de consolidação do Estado Democrático de Direito e de promoção e proteção dos direitos humanos". In: Maria Paula Bucci. (Org.) Políticas Públicas: Reflexões sobre o conceito jurídico. São Paulo: Saraiva, p. 217-246.

ANJOS FILHO, Robério dos, Fontes do Direito ao Desenvolvimento no Plano Internacional In: PIOVESAN, Flávia e SOARES, Inês Virginia Prado (Coord). Direito ao Desenvolvimento, Belo Horizonte: Editora Forum, 2010, p.117-153

ANCAT - Movimento Nacional dos Catadores e Catadora de Materiais Recicláveis, Busca pela inclusão social de toda a categoria, Disponível http://www.mncr.org.br/sobre-o-mncr/notas-e-declaracoes/mncr-15-anos-de-lutasrevolucionando-histori, acessado em 21/11/2017

ASMARE - Associação dos Catadores de Papel, Papelão e Materiais Reaproveitáveis de Belo Horizonte, História. Disponível em hppt//www.asmare.org, acessado em 23.05.2016

ASSOCIAÇÃO BRASILEIRA DE EMPRESAS DE LIMPEZA PÚBLICA E RESÍDUOS ESPECIAS. Panorama dos resíduos sólidos no Brasil: 2015. Disponível em < http://www.abrelpe.org.br/> acessado em 16.08.2017.

ASSOCIAÇÃO TÉCNICA BRASILEIA DAS INDÚSTRIAS DE VIDRO - ABIVIDRO, Glass is good todo mundo reciclando vidro. Disponível em http://www.abividro. org.br/noticias/conheca-o-projeto-glass-good. Acessado em 14/12/2017.

BESEN Gina Rizpah, JACOBI, Pedro Roberto, Acordo Setorial de Embalagens PósConsumo no Brasil: Consulta Pública e Remuneração e Catadores de Materiais Recicláveis, In. JACOBI, Pedro Roberto, FREITAS, Luciana (Org.), Política Nacional de Resíduos Sólidos - Implementação e monitoramento de resíduos 
urbanos, São Paulo: Editoração eletrônica produção Rai Lopes Pereira, junho/2017, p 7090.

BERCOVICI, Gilberto, O artigo 23 da Constituição de 1988 e as competências comuns. In. Revista Brasileira de Estudos Constitucionais - RBEC, Belo Horizonte, ano 2, n. 6, 49-65, abr-jun, 2008,

ANTUNES, Paulo Bessa. Direito Ambiental. 6 ed. Rio de Janeiro: Lumen Júris, 2002.

Dano Ambiental: do individual ao coletivo extrapatrimonial, 2 ed , São Paulo: Revista dos Tribunais, 2003.

BENJAMIN, Antonio Herman V. Função Ambiental. In: Dano ambiental; prevenção, repressão e reparação. São Paulo: Revista dos Tribunais, 1993.

BOBBIO, Norberto. A Era dos Direitos. 12 ed. Rio de Janeiro: Editora Campus, 1992.

BOITEUX, Elza Antonia Pereira Cunha. O princípio da solidariedade e os direitos humanos de natureza ambiental. In: Revista da Faculdade de Direito da Universidade de São Paulo, 2010, vol. 105.

BUCCI, Maria Paula Dallari, Fundamentos para uma Teoria Jurídica das Políticas Públicas. São Paulo: Saraiva, 2013.

CAMPINHO Bernardo Brasil, O Direito ao Desenvolvimento como Afirmação dos Direitos Humanos - Delimitação, Sindicabilidade e Possibilidades Emancipatórias, In: PIOVESAN, Flávia, SOARES, Inês Virginia Prado (Coord), Direito ao Desenvolvimento, Belo Horizonte: Ed. Fórum, 2010, p.159-162

CANOTILHO, José Joaquim Gomes. Proteção do Ambiente e direito de propriedade. Coimbra: Almedina, 1995.

Direito Constitucional e Teoria da Constituição. 2. ed. Coimbra:

Almedina, 1998. 
CAPELlA, Ana Cláudia. N. Perspectivas teóricas sobre o processo de formulação de políticas públicas. IN: BIB, Revista Brasileira de Informação Bibliográfica em Ciências Sociais, v. 61, 2006, p. 20-40.

CARAMENHA, Roberto. Município e Meio Ambiente: É possível a implementação de uma gestão ambiental adequada?. In: Temas de Direito Urbanísticos 4. São Paulo: Ministério Público do Estado de São Paulo, Procuradoria Geral de Justiça / Imprensa Oficial, 2005, v. 4, p. 219-235.

CARVAlHO, Ramos André de, Teoria Geral dos Direitos Humanos na Ordem Internacional, $5^{\mathrm{a}}$ ed., Sã Paulo: Saraiva, 2015.

CARVALHO, Juliane Erthal, A importância da Consensualidade na Implementação da Logística Reversa, Dissertação de Mestrado, Faculdade de Direito, Universidade de São Paulo, São Paulo, 2015.

COMPROMISO EMPRESARIAL PARA RECICLAGEM - CEMPRE, Institucional , Disponível em http://cempre.org.br/sobre/id/1/institucional. Acessado em 12/12/2016. Informativo $\mathrm{n}^{\circ}$ 144, ano 22, novembro/dezembro de 2015.

CIPRIANO, Tasso Alexandre Richetti Pires, $O$ conceito de fabricante no Direito Brasileiro os Resíduos, Revista de Direito Ambiental, ano, 22, vol 86, abr-jun, 2017, p. 239-255

Juridificação dos Resíduos no Brasil, Direito Ambiental e Sustentabilidade, In: PHILIPPI JR Arlindo, FREITAS, Vladimir Passos, e SPÍNOLA (editores), Coleção Ambiental - vol 18, Barueri: Manole, 2016, p. 168/172;

CHRISTON, Teodora, Human Rights Manual for Palestinian Lawers, Identifying, Investigating and Prosecuting Human Rights Violations. LONDON: WC2A3LS, 2006.

COMPARATO, Fábio Konder, A afirmação histórica dos Direitos Humanos. 4 ed. São Paulo: Ed. Saraiva, 2005. 
Ensaio sobre o juízo de constitucionalidade de políticas públicas. In: Revista de Informação Legislativa, Brasília, a.35, n. 138, abr/jun. 1998. p. 3948.

CONECTAS. Princípios Orientadores Ruggie. Disponível em http://www.conectas.org/arquivos-site/Conectas_PrincípiosOrientadoresRuggie acessado em 03/10/2017

COOPAMARE - Cooperativa de Catadores Autônomos de Papel, Papelão, Aparas e Materiais Reaproveitáveis, Como tudo começou., Disponível em http//www.coopamare.org.br>, acessado em 15.05.2016.

CONSElHO NACIONAL DE JUSTIÇA - CNJ, $1^{\circ}$ Balanço Socioambienal do Poder Judiciário, Disponível em http://www.cnj. jus.br/files/conteudo/arquivo/2017/10/c8731235bf90f4ed2a10162e6c14436b.pdf.

Acessado em 30/11/2017.

COURTIS, Christian e ABRAMOVICH, Victor. Los derechos sociales como derechos exigibles. Madrid: Trotta, 2002, p. 117-254

D’ALMEIDA, Maria Luiza Otero, VILHENA André (Coord), Lixo Municipal: Manual de Gerenciamento Integrado, 2 ed. São Paulo: IPT/Cempre, 2000.

DALLARI, Dalmo de Abreu, Implicações do Pacto Federativo In. Dircêo Torrecillas Ramos (Coord), O Federalista Atual, Belo Horizonte: Arraes Belo, 2013. p. 499-594.

DEMAJOROVIC, Jacques, LIMA, Márcia, Cadeia de reciclagem uma olhar para os catadores, São Paulo: ed. Senac, 2013;

DIAS, Jefferson Aparecido, MORAES FILHO, Atalida Monteiro, Os resíduos sólidos e a responsabilidade ambiental - Disponível em: http://www.prsp.mpf.mp.br/sala-deimprensa/livro_pos_consumo_2ed.pdf acessado 12/04/2016.

DINIZ, Maria Helena, Curso de Direito Civil Brasileiro, 7. Responsabilidade Civil. , 23 ed, São Paulo: Saraiva, 2009

KELSEN, Hans, Teoria Geral do Direito e do Estado, 17 ed. São Paulo: Saraiva, 2001. 
DERANI, Cristiane. Direito Ambiental Econômico São Paulo: Saraiva, 2008.

Meio Ambiente Ecologicamente Equilibrado: Direito Fundamental e Princípios da Atividade Econômica. In: FIGUEIREDO, Guilherme José Purvin de (Org.). Temas de Direito Ambiental e Urbanístico. São Paulo: Max Limonad, 1998, p. 91-101.

DORINE, Raquel Pereira. Desenvolvimento Sustentável como responsabilidade social das empresas - Um enfoque ambiental. São Paulo, 1999. Dissertação de Mestrado em Direito das Relações Sociais, Faculdade de Direito, Pontifícia Universidade Católica de São Paulo.

EMPLASA - Empresa Metropolitana de Planejamento da Grande São Paulo/SP Fundamentos para o equacionamento da Destinação Final dos Resíduos Sólidos na R.M.S.P versão preliminar junho/1992

FERRAZ, Ágata Bobbi, A articulação Federativa Para a Viabilidade da Política Nacional de Resíduos Sólidos no Brasil, Dissertação de Mestrado, Faculdade de Direito, Universidade de São Paulo - São Paulo, 2014;

FERREIRA, Heline Sivini. Política Ambiental Constitucional. In. CANOTILHO, José Joaquim Gomes e LEITE, José Rubens Morato (Orgs), Direito Constitucional Ambiental Brasileiro.São Paulo: Saraiva, 2007, p. 230-262.

FERREIRA FILHO, Manoel Gonçalves, Curso de Direito Constitucional, 39 ed. São Paulo: Saraiva, 2013,

FERRER Luzell, Human Rights Law I Introduciton: Definition Of Human Rights Sources Of Human Right Construction Of Human Right Law Atributes of Human Right. São Francisco, 2014.

FLEINER, Thomas, A dignidade humana e a liberdade somente podem existir se os direitos à liberdade são completados pelos direitos sociais. O que são os direitos humanos, São Paulo, ed. Max Limonad, 2003.

FRANCHINI NETO, Miguel, Os Direitos Humanos da ONU, Rio de Janeiro: Editora Livraria Freitas Bastos S.A, 1979. 
ESPIELL, GROS, Hector, Los derechos econômicos, sociales y culturares en el sistema interamericano. San José: Libro Libre, 1986, p.-16-17.

FIGUEIREDO, Guilherme José Purvin de. Resíduos sólidos: ponto final da insustentabilidade econômica. Revista de Direitos Difusos, v. 13, p. 1717-1731, jun. 2002.

FIQUEIREDO, Ivanilda, O Direito ao Desenvolvimento Humano: Uma sugestão sobe a definição desse conceito, In: BITTAR Eduardo C.B (Coord), Direito Humanos XXI Trabalhos reunidos pela Associação Nacional de Direitos Humanos - ANDREP . São Paulo: 2009, p. 27-33.

GALDINO, Flávio. O custo dos direitos. In: TORRES, Ricardo Lobo (Org.) Legitimação dos direitos humanos. Rio de Janeiro: Renovar, 2002, pp. 139-222.

GOHN, Maria da Gloria, Movimentos Sociais na Contemporaneidade, Revista Brasileira de Educação v. 16 n 47, maio-ago, 2011, p. 333-361.

GONÇALVES, Carlos Roberto, Responsabilidade Civil. 4 vol., 5 ed., São Paulo: Saraiva, 2010.

GRINOVER, Ada Pellegrini, O controle de políticas públicas pelo Poder Judiciário. In Revista Brasileira de Estudos Constitucionais, Belo Horizonte, v. 2. n.8, out. 2008.

GUNDER, André, FUENTES, Marta, Dez teses acerca dos movimentos sociais: Lua Nova: Revista de Cultura e Política, 1989;

Instituto Brasileiro de Geografia e Estatística - IBGE Pesquisa Nacional Censo Demográfico/2010, Rio de Janeiro: IBGE, 2012.

População estimada. Disponível em

https://cidades.ibge.gov.br/brasil/sp/sao-paulo/panorama acessada em 23/12/2017.

Instituto de Pesquisa Econômica Aplicada - IPEA Diagnóstico dos Resíduos Sólidos Urbanos - Relatório de pesquisa, Brasília: Ipea, 2012.

Situação Social das Catadoras e dos Catadores de Material Reciclável e Reutilizável Brasil, Brasília - 2013 Disponível em 
http://www.ipea.gov.br/agencia/images/stories/PDFs/situacao_social/131219_relatorio_sit uacaosocial_mat_reciclavel_brasil.pdfacessado em 23.05.2016.

Pesquisa Sobre Pagamento por Serviços Ambientais Urbana

para Gestão de Resíduos Sólidos. Brasília: Ipea, 2010. Disponível em http://www.ipea.gov.br/portal/images/stories/PDFs/100514_relatpsau.pdf, acessado em 04.06.2016.

Relatório de Pesquisa Boas Práticas de Gestão de Resíduos Urbanos e de Logística Reversa com a Inclusão de catadores de Materiais Recicláveis, Disponível em: http://rededegestoresecosol.org.br/wpcontent/uploads/2015/11/livro_relatorio_boas_pratica s_catadores1.pdf acessado 04.02.2017.

INpev. Logística Reversa Destinação das embalagens. Disponível em http://www.inpev.org.br/logistica-reversa/destinacao-das-embalagens/unidades-derecebimento: acessado em 23.05.2016.

KRELL, Andreas, Leis e Normas gerais, regulamentação do Poder Executivo e cooperação intergovernamental. Belo Horizonte: Fórum, 2008.

KNOLL, Alesandra, O Programa Pró-Catador e a Nova Política Nacional de Resíduos Sólidos:: Uma análise da Associação de Coletores de Materiais Recicláveis, Dissertação de Mestrado, da Universidade Federal de Santa Catarina, 2014.

LAFFER, Celso, Direitos Humanos e democracia no plano interno e internacional. In Desafios: Ética e Política, São Paulo: Siciliano, 1995, p. 201-211.

LANFREDI, Geraldo Ferreira. Política Ambiental: busca da efetividade e seus instrumentos. São Paulo: Revista dos Tribunais, 2002.

LEITE, José Rubens Morato, Dano Ambiental: do individual ao coletivo extrapatrimonial. 2 ed. São Paulo: Revista dos Tribunais, 2003.

LEMOS, Patrícia Faga Iglecias, Resíduos Sólidos e Responsabilidade Civil PósConsumo,2 ed. São Paulo: Revista dos Tribunais, 2012. 
LIMA, Sonia; GRIMBERG, Elisabeth, Programa Lixo e Cidadania. Disponível em 〈www.mobilizadores.org.br $>$, acessado em 14.05.2016.

LOZANO, Rubén Serrano, la Nueva Regulación Europea de Residuos: Hacia el Logro de uma Sociedad Europea del Reciclado, la Implantacion de la Responsabilidad Ampliada del Produto y su Transposición em España, In SILVA, Solange Teles da Silva, CUREAU, Sandra, LEUZINGER, Márcia Dieguez, (Coord) Resíduos Sólidos, São Paulo: Fiuza, 2013, p. $277-310$

MACHADO, Paulo Afonso Leme. Direito Ambiental Brasileiro. 14 ed. São Paulo: Malheiros, 1998.

MAIA, José Benedito de Zarzuela, verbete "Desenvolvimento econômico" In: Dicionário de Direitos Humanos. Disponível em: 〈www.esmpu.gov.br/dicionario, acesso maio/2016〉

MELLO, Celso Antonio Bandeira, Eficácia das Normas Constitucionais e Direitos Sociais, $1^{\mathrm{a}}, 4^{\mathrm{a}}$ tiragem, São Paulo: Malheiros, 2015.

MENDES, João Mucio Amado, Responsabilidade compartilhada pelo ciclo de vida do produto na cadeia de resíduos eletroeletrônicos, Dissertação de Mestrado, Faculdade de Direito, Universidade de São Paulo, 2015.

MEREDITH, Mcbride, Ethics in Action Indonesian Migrant Workers in Hon kong exploited and forgotten. vol. 8. n. 2, april/2014. Hong Kong: Asia Human Rights Commession Ltd 2 (AHRC), 2014.

MIGUEZ, Eduardo Correia. Logística reversa como solução para o problema do lixo eletrônico: benefícios ambientais e financeiros, Rio de Janeiro: Qualitymark, 2010.

MILLER JR, G. Tyler, Ciência Ambiental, tradução All Tasks. 11ª ed. Norte-Americana. São Paulo: Cengage Learding, 2008.

MINISTÉRIO DO MEIO AMBIENTE. A Problemática "Resíduos Sólidos": Contexto e Principais Aspectos. disponível http://www.mma.gov.br/cidades-sustentaveis/residuossolidos/politica-nacional-de-residuos-solidos/contextos-e principais-aspectos, acessado em 04/04/2016. 
Declaração Final da Conferência das Nações Unidas Sobre $\begin{array}{lllll}\text { Desenvolvimento } & \text { Sustentável } & \text { Rio } & \mathbf{+ 2 0} \text { ) disponível em }\end{array}$ http://www.mma.gov.br/port/conama/processos/61AA3835/O-Futuro-que-queremos1.pdf, acessado em 19/10/2017.

MNCR - Movimento Nacional dos Catadores de Materiais Recicláveis, objetivos e princípios. Disponível em http://www.mncr.org.br/sobre-o-mncr/principios-e-objetivos acessado em 11.04.2016.

A importância dos Catadores já foi aceita agora o debate é sobre a sua valorização. Disponível em http://www.mncr.org.br/artigos/201caimportancia-dos-catadores-ja-foi-aceita-agora-o-debate-e-sobre-a-sua-valorizacao201d, acessado em 11/10/2017.

MOREIRA, Danielle de Andrade. "Responsabilidade ambiental pós-consumo". In. Revista de direito ambiental, v. 63, p. 157-180, jul.-set. 2011.

MOREIRA, José Carlos Barbosa. "Os deveres para com a comunidade". In: Temas de direito processual. Rio de Janeiro: Saraiva, 1997, p. 309-317.

MOYN, Samuel. The last utopia. Cambridge: Belknap Harvard, 2010, pp. 176-211

MOURAD, Anna Lúcia; GARCIA, Eloísa E. C.; VILHENA, André, Avaliação do Ciclo de Vida: princípios e aplicações. Campinas: CETEA/CEMPRE, 2002.

NIVARDA, Carole, La justiciabilité des droits sociaux Étude de droit conventionnel européent, Belgique: Éditions Bruyland, 2012.

Novas Perspectivas do Direito Urbanístico Brasileiro. Ordenamento Constitucional Aplicação e eficácia do Plano Diretor, p. 105.

NOVELLI, Mariano H. "La Justicia en el Decrecho Ambiental”. In: Revista del centro de investigaciones de filosofia jurídica y filosofia Social, 2009, n. 32, p. 81-94.

NUSDEO, Ana Maria de Oliveira. Pagamento por serviços ambientais, sustentabilidade e disciplina jurídica. São Paulo: Atlas, 2012. 
NUSDEO, Fábio. Direito econômico ambiental. In: ALVES, Alaor Caffé; PHILIPPI JR., Arlindo (Coords.) Concurso interdisciplinar de direito ambiental. Barueri, SP: Manole, 2005, p. 717-738.

ONU - ORGANIZAÇÃO DAS NAÇÕES UNIDAS. Transformando Nosso Mundo: A Agenda 2030 para o Desenvolvimento Sustentável , disponível em https://nacoesunidas.org/pos2015/agenda2030/ acessado em 18/08/2017.

PASQUALETTO, Olívia de Quintana Figueiredo, A proteção do trabalhador nos trabalhos verdes, Dissertação (Mestrado), Faculdade de Direito - Universidade de São Paulo, 2016.

PEREIRA, André Luiz; BOECHAT, Cláudio Bruzzi; TADEU, Hugo Ferreira Braga; SILVA, Jersone Tasso Moreira; CAMPOS, Paulo Március Silva. Logística reversa e sustentabilidade, São Paulo: Cengage Learning, 2012.

PEREIRA, Bruna Cristina Jaquetto e GOES, Fernanda Lira (Org.) Catadores de materiais recicláveis: um encontro nacional. Rio de Janeiro: Ipea, 2016.

PIOVESAN, Flávia, Direito ao Desenvolvimento- Desafios Contemporâneos. In: SOARES, Inês Virginia Prado (Coords). Direito ao Desenvolvimento, Belo Horizonte: Editora Forum, 2010, p. 95/114.

Disponível em http:conectas.org/pt/ações/sur/edição1/1000226direitos-sociais economicos-e-culturais>, acessado em 14.10.2015.

Temas de Direitos Humanos, São Paulo: Max Limonard, 1998.

PHILIPPI, Arlindo Jr.; BRUNA Gilda Collet; SILVEIRA, Vicente Fernando. Políticas Públicas e Desenvolvimento Sustentável, In: PHILIPPI, Vicente Jr, ALVES, Alôr Caffé. Curso Interdisciplinar de Direito Ambiental, Barueri: Manole, 2005 , p. 789-810.

PLINIO, Marcos, Homem de papel, São Paulo: Peça de Teatro, Global, 1978;

Prefeitura do Município de São Paulo, Plano de Gestão Integrada de Resíduos Sólidos,disponível em 
http://www.prefeitura.sp.gov.br/cidade/secretarias/upload/servicos/arquivos/PGIRS-

2014.pdf, acessado em 11/11/2017

Programa de Metas. Disponível em

http://planejasampa.prefeitura.sp.gov.br/assets/Programa-de-Metas_2017-2020_Final.pdf, acessado em 11/11/2017

PRUDENTE, Eunice Aparecida de Jesus, O direito de ser e participar de São Paulo, In.

MEDINA, cremilda, GRECO Milton (Orgs), Sobrevivências no mundo do trabalho, Projeto de Pesquisa Integrada Junto ao CNPq, 1995.

RAMOS, André de Carvalho, Teoria Geral dos Direitos Humanos na ordem internacional, ed. 5a, São Paulo: Saraiva, 2015.

REVEILlEAU, Ana Célia Alves de Azevedo, SOARES, Inês Virginia Prado, Logística Reversa e Gerenciamento dos Resíduos Sólidos, In SILVA, Solange Teles da Silva, CUREAU, Sandra, LEUZINGER, Márcia Dieguez, (Coords) Resíduos Sólidos, São Paulo: Fiuza, 2013, p. 115/136.

RIBEIRO, Helena, JACOBI, Pedro Roberto, BESEN, Gina Rizpah, GUNTHER, Wanda Maria Risso, DEMAJOROVIC, Jacques e VIVEIROS, Mariana, Coleta Seletiva com Inclusão Social, cooperativismo e sustentabilidade, São Paulo: AnnaBlume, 2009.

JACOBI, Pedro Roberto, BESEN, Gina Rizpah, GUNTHER, Wanda Maria Risso, DIAS, SONIA MARIA, Gestão da Coleta Seletiva e de Organização de Catadores: indicadores e índices de sustentabilidade, São Paulo: Universidade de São Paulo, Faculdade de Saúde Pública, 2016.

ROMERO, Marcos. Consultoria Para Los Derechos Humanos: Y El Desplazamiento , CODHES, www.codlhes.org. 2014.

SAAD, Amauri Feres, Regime Jurídico das Políticas Públicas, São Paulo, Malheiros, 2016.

SCAFF, Fernando Facury, Financiamento público para as políticas públicas dos direitos humanos, In. ANDHEP -BITTAR, Eduardo, C.B. (Coords), Direito Humanos no Século 
XXI, Cenário de Tensão, Trabalhos reunidos pela Associação Nacional de Direitos Humano. p. 94-106 São Paulo: Ed. Forense Universitária, 2009, p. 94-106.

SALCEDO, Juan Antonio Carrillo. "El derecho al desarrollo como derecho de la persona humana”. Revista Española de Derecho Internacional, v. XXV, 1972 apud ESPIEL, Hector Gross. Elderecho al desarrollo como un derecho humano. Revista de Estudios Internacionales, n. 1, p. 45, mar. 1980, p. 119-125.

SALDANHA, Pedro Mallmann. Logística Reversa: instrumento de solução para a problemática dos resíduos sólidos em face da gestão ambiental. Revista de direito ambiental, v. 65, p. 101-132, jan. 2012.

SALOMÃO FILHO, Calixto, Menos Mercados, Mais Direitos Humanos, BERCOVICI, Gilberto, SOUZA, Luciano Anderson, FERREIRA, Lauro Cesar Mazetto (Coord), Desafios dos Direitos Humanos no Século XXI, São Paulo: ed. Quartier Latin do Brasil, 2016, p. $70 / 71$.

SANT'ANA, Diogo, METELLO, Daniela, Reciclagem e Inclusão Social no Brasil: Balanços e Desafios, IN: PEREIRA, Bruna Cristina Jaquetto e GOES, Fernanda Lira (Orgs) Catadores de materiais recicláveis: um encontro nacional. Rio de Janeiro: Ipea, 2016.

Disponível

em

http://www.ipea.gov.br/portal/images/stories/PDFs/livros/livros/160331_livro_catadores.p df acessado 12/12/2017.

SARLET, Ingo Wolgang. "Estado socioambiental e direitos fundamentais", In: Sarlet Ingo Wolfgang (Org), Direito humanos, meio ambiente e sustentabilidade, Porto Alegre: Livraria do Advogado, 2010, p. 73-109.

O direito à garantia de uma existência digna: a problemática do salário mínimo, da assistência social, do direito à previdência social e do direito à saúde In: A Eficácia dos direitos Fundamentais. Porto Alegre: Livraria do Advogado, 2001.

SCHWAR, Rodrigo Garcia, Judicialização de políticas: uma introdução à temática do controle judicial sobre as respostas dos poderes públicos às demandas sociais In: (Org.) Direito Administrativo Contemporâneo: Administração Pública, 
Justiça Constitucional e Cidadania: Garantias fundamentais e direitos sociais São Paulo: Elsevier, 2010, p. 1-28.

SELUR - Sindicato das Empresas de Limpeza Urbana do Estado de São Paulo, ISLU Índice de Sustentabilidade de Limpeza Urbana para os Municípios Brasileiros. Disponível em https://www.selur.com.br/publicacoes/islu-indice-de-sustentabilidade-dalimpeza-urbana-para-os-municipios-brasileiros/acessado em 11/11/2017.

SEN, Amartya, Desenvolvimento como liberdade. São Paulo: Companhia das Letras, 2008.

SERRA, Tatiana Barreto, Política de Resíduos Sólidos, Gestão econômica, responsável e ambientalmente correta, São Paulo, Editora Verbatim, 2015.

SEVERI, Fabiana Cristina, Os catadores de materiais recicláveis e reutilizáveis na Política Nacional de Resíduos Sólidos, Revista Direito e Praxis, vol. 5, n.8, 2014, p 152171 Disponível em meio eletrônico e acessada em 14/12/2017.

SILVA, Allyne Andrade, Direito, Desenvolvimento e Política Pública: Uma Análise jurídica do Programa Brasil Quilombola, Dissertação de Mestrado, Faculdade de Direito, Universidade de São Paulo, 2015.

SILVA, José Afonso da, A dignidade da pessoa humana como valor supremo da democracia Revista de Direito Administrativo no 212, 1998, p 92.

SIMAS, André Luiz Fernandes e PERE, Zuleika Maria de Lisboa (Org) Plano de Resíduos Sólidos do Estado de São Paulo [recurso eletrônico], Secretaria do Meio Ambiente do Estado de São Paulo, Coordenadoria de Planejamento Ambiental , CETESB; $1^{a}$ ed. São Paulo: SMA, 2014 disponível em http://www.ambiente.sp.gov.br, acessado $19 / 10 / 2017$.

SINGER, Paul, As grandes questões do trabalho no Brasil e a economia solidária, Revista proposta $\mathrm{n}^{\circ}$ 97, jan/ago, 2003, p. 204.

SINIR - Sistema Nacional de Informações Sobre a Gestão dos Resíduos Sólidos. Plano Nacional de Resíduos Sólidos, Disponível em http://www.sinir.gov.br/web/guest/planonacional-de-residuos-solidos, acessado em 24/10/2017. 
SIRVINSKAS, Luís Paulo, Manual de Direito Ambiental, 6ª ed. São Paulo: Saraiva, 2008.

SOARES, Inês Virginia Prado, Proteção Jurídica do Patrimônio Arqueológico No Brasil, Tese de Doutorado, Pontifícia Universidade Católica de São Paulo, 2007.

SUPERIOR TRIBUAL DE JUSTIÇA - Agravo Regimental desprovido, AgRg no AREsp 422.078/MS, Rel. Ministra ASSUSETE MAGALHÃES, julgado em 09/09/2014, DJe $16 / 09 / 2014$.

Recurso Especial $\mathrm{n}^{\circ}$ 1.367.549 - MG (2011/0132513-5), julgado em 02/09/2014, Rel.Ministro HUMBERTO MARTINS, DJe 08/09/2016.

Conflito de Competência n.133.373-PR - decisão monocrática proferida em 13.02.2015, Relator Min. OG Fernandes. Suscitante: Juízo de Direito da Vara Civel e Anexo do Foro Regional da Fazenda do Rio Grande - PR; Suscitado: Tribunal Regional do Trabalho da $9^{a}$ Região; Interessados: Ministério Público do Trabalho e Meco Madeira Remanufaturada Ltda Disponível em http://www.stj.jus.br/SCON/decisoes/toc.jsp?livre=programa++e+coleta++e+seletiva\&\&b =DTXT\&thesaurus=JURIDICO\&p=true\#DOC1, acessado em 12/12/2017.

TAVARES, André Ramos, Federalismo Social, In. Dircêo Torrecillas Ramos (Coord), O Federalismo Atual, Belo Horizonte: Arraes Belo, 2013, p. 240.

TOMÉ, Filipe Ferrari; TOMÉ, Maria Vitória Ferrari; e BLUMENSCHERI, Raquel Neves, A Política Brasileira de Resíduos Sólidos: Os Desafios da Teoria e da Prática. In. SILVA Solange da Silva, CUREAU, Sandra, LEUZINGER, (Coord), Resíduos, São Paulo: Fiuza, 2013; p. 13-32.

TRIBUNAL DE CONTAS DA UNIÃO. Segunda Câmara, Relatora Ministra Ana Arraes, Acórdão $\quad \mathrm{n}^{\circ} \quad 5804 / 2013, \quad$ Disponível em https://contas.tcu.gov.br/etcu/ObterDocumentoSisdoc?seAbrirDocNoBrowser=true\&codAr qCatalogado=6526154, acessado em 14/08/2017.

TRIBUNAL DE CONTAS DO ESTADO DE SÃO PAULO, $7^{\mathbf{a}}$ Fiscalização Ordenada de Resíduos Sólidos, Disponível em https://www4.tce.sp.gov.br/sites/tcesp/files/downloads/consolidado31-10-2017_0.pdf acessado em 06/11/2017. 
TRIBUNAL DE JUSTIÇA DO ESTADO DO PARANÁ - $8^{\mathrm{a}}$ Câmara .Cível - AC 118652-1 - Curitiba - Rel.: Ivan Bortoleto - Unânime - julgamento em 05.08.2002. Disponível em https://portal.tjpr.jus.br/jurisprudencia/j/1393017/Ac, acessado $16 / 11 / 2017.1$

TRIBUNAL DE JUSTIÇA DE SÃO PAULO - Consulta Processual - $1^{\circ}$ Grau. Proc. Ação Popular, $n^{\circ}$ 0004373-79.2014.8.26.0068, proposto em 25.02.2014, em trâmite na Vara da Fazenda Pública - Foro de Barueri - SP.

TRINDADE, Antônio Augusto Cançado. Direitos Humanos e Meio Ambiente. Porto Alegre : Editor Sérgio Antonio Fabris, 1993.

"O legado da declaração universal dos direitos humanos e sua trajetória ao longo das seis últimas décadas (1948-2008)”. In GIOVANNETTI, Andrea (Org.) 60 anos da Declaração Universal dos Direitos Humanos. Brasília: FUNAG, 2009, p. 13-46.

TAVARES, Andre Ramos, Federalismo Social, In. Dircêo Torrecillas Ramos (Coord), $O$ Federalismo Atual, Belo Horizonte: Arraes Belo, 2013, p. 240.

WATANABE, Kazuo, Controle jurisdicionais das Políticas Públicas - " mínimo existencial" e demais direitos fundamentais imediatamente judicializáveis. In. GRINOVER, Ana Pellegrini; WATANABE Kazuo (Coord), O Controle jurisdicional de políticas Públicas. Rio de Janeiro: Forense, 2013.

WINTER, Gerd, Desenvolvimento Sustentável, OGM e Responsabilidade Civil na União Europeia. MACHADO, Paulo Affonso Leme e KISHI Sandra Akemi Shimada (Orgs), São Paulo: Millennium, 2009.

\section{UNICEF - FUNDO DAS NAÇÕES UNIDAS PARA INFÂNCIA - Campanha Criança}

no Lixo, Nunca Mais. Trata-se de um apelo nacional pela erradicação do trabalho infantil nos lixões e na coleta de lixo nas ruas. Essa campanha deu visibilidade ao tema até então oculto no país. Disponível https://www.unicef.org/brazil/pt/overview_9489.html, acessado em 13/09/2017. 
VALLIN, Carvalho Isabella, TEIXEIRA Soares Elisangela, SAMPAIO Sandra, PAULA Eduardo Ferreira De DIAS, Sylmara Lopes Francelino Gonçalves, Artigo apresenta XI Seminário Nacional de Resíduos Sólidos, IV-002 Perfil Sociodemográfico dos Catadores de Materiais Recicláveis do Município de São Paulo.

VIEIRA, José Eli, Desenvolvimento Sustentável. O Desafio do Século XXI. São Paulo: Garamond, 2005.

VIEIRA, Ricardo Stannziola. "Desenvolvimento, Sustentabilidade e Justiça Ambiental algumas novas perspectivas para o direito à sustentabilidade”. Organizadores: PERALTA, Carlos E, AUGUSTIN, Sérgio, ALVARENGA, Luciano J. Direito e Justiça Ambiental: diálogos interdisciplinares sobre a crise ecológica, Caxias do Sul-RS: Educs, 2014, p. 330-348.

YOSHIDA, Consuelo, Competências e as diretrizes da PNRS. In:

JARDIM, Arnaldo; MACHADO FILHO, José Valverde, Política Nacional, Gestão e Gerenciamento de Resíduos Sólidos. Barueri: Manole, 2012, p. 3-38. 


\section{Presidência da República \\ Casa Civil \\ Subchefia para Assuntos Jurídicos}

LEI No 12.305, DE 2 DE AGOSTO DE 2010.

$\underline{\text { Regulamento }}$

Institui a Política Nacional de Resíduos Sólidos; altera a Lei $\mathrm{n}^{\mathrm{0}}$ 9.605, de 12 de fevereiro de 1998; e dá outras providências.

O PRESIDENTE DA REPÚBLICA Faço saber que o Congresso Nacional decreta e eu sanciono a seguinte Lei:

\section{TÍTULO I}

\section{DISPOSIÇÕES GERAIS}

\section{CAPÍTULO I}

\section{DO OBJETO E DO CAMPO DE APLICAÇÃO}

Art. $1^{\mathrm{o}}$ Esta Lei institui a Política Nacional de Resíduos Sólidos, dispondo sobre seus princípios, objetivos e instrumentos, bem como sobre as diretrizes relativas à gestão integrada e ao gerenciamento de resíduos sólidos, incluídos os perigosos, às responsabilidades dos geradores e do poder público e aos instrumentos econômicos aplicáveis.

$\S 1^{o}$ Estão sujeitas à observância desta Lei as pessoas físicas ou jurídicas, de direito público ou privado, responsáveis, direta ou indiretamente, pela geração de resíduos sólidos e as que desenvolvam ações relacionadas à gestão integrada ou ao gerenciamento de resíduos sólidos.

$\S 2^{\circ}$ Esta Lei não se aplica aos rejeitos radioativos, que são regulados por legislação específica.

Art. $2^{\circ}$ Aplicam-se aos resíduos sólidos, além do disposto nesta Lei, nas Leis $\mathrm{n}^{\text {os }}$ $\underline{11.445}$, de 5 de janeiro de 2007, 9.974, de 6 de junho de 2000, e 9.966, de 28 de abril de $\underline{2000}$, as normas estabelecidas pelos órgãos do Sistema Nacional do Meio Ambiente (Sisnama), do Sistema Nacional de Vigilância Sanitária (SNVS), do Sistema Unificado de Atenção à Sanidade Agropecuária (Suasa) e do Sistema Nacional de Metrologia, Normalização e Qualidade Industrial (Sinmetro).

\section{CAPÍTULO II}

\section{DEFINIÇÕES}

Art. $3^{\circ}$ Para os efeitos desta Lei, entende-se por: 
I - acordo setorial: ato de natureza contratual firmado entre o poder público e fabricantes, importadores, distribuidores ou comerciantes, tendo em vista a implantação da responsabilidade compartilhada pelo ciclo de vida do produto;

II - área contaminada: local onde há contaminação causada pela disposição, regular ou irregular, de quaisquer substâncias ou resíduos;

III - área órfã contaminada: área contaminada cujos responsáveis pela disposição não sejam identificáveis ou individualizáveis;

IV - ciclo de vida do produto: série de etapas que envolvem o desenvolvimento do produto, a obtenção de matérias-primas e insumos, o processo produtivo, o consumo e a disposição final;

V - coleta seletiva: coleta de resíduos sólidos previamente segregados conforme sua constituição ou composição;

VI - controle social: conjunto de mecanismos e procedimentos que garantam à sociedade informações e participação nos processos de formulação, implementação e avaliação das políticas públicas relacionadas aos resíduos sólidos;

VII - destinação final ambientalmente adequada: destinação de resíduos que inclui a reutilização, a reciclagem, a compostagem, a recuperação e o aproveitamento energético ou outras destinações admitidas pelos órgãos competentes do Sisnama, do SNVS e do Suasa, entre elas a disposição final, observando normas operacionais específicas de modo a evitar danos ou riscos à saúde pública e à segurança e a minimizar os impactos ambientais adversos;

VIII - disposição final ambientalmente adequada: distribuição ordenada de rejeitos em aterros, observando normas operacionais específicas de modo a evitar danos ou riscos à saúde pública e à segurança e a minimizar os impactos ambientais adversos;

IX - geradores de resíduos sólidos: pessoas físicas ou jurídicas, de direito público ou privado, que geram resíduos sólidos por meio de suas atividades, nelas incluído o consumo;

X - gerenciamento de resíduos sólidos: conjunto de ações exercidas, direta ou indiretamente, nas etapas de coleta, transporte, transbordo, tratamento e destinação final ambientalmente adequada dos resíduos sólidos e disposição final ambientalmente adequada dos rejeitos, de acordo com plano municipal de gestão integrada de resíduos sólidos ou com plano de gerenciamento de resíduos sólidos, exigidos na forma desta Lei;

XI - gestão integrada de resíduos sólidos: conjunto de ações voltadas para a busca de soluções para os resíduos sólidos, de forma a considerar as dimensões política, econômica, ambiental, cultural e social, com controle social e sob a premissa do desenvolvimento sustentável;

XII - logística reversa: instrumento de desenvolvimento econômico e social caracterizado por um conjunto de ações, procedimentos e meios destinados a viabilizar a coleta e a restituição dos resíduos sólidos ao setor empresarial, para reaproveitamento, em seu ciclo ou em outros ciclos produtivos, ou outra destinação final ambientalmente adequada; 
XIII - padrões sustentáveis de produção e consumo: produção e consumo de bens e serviços de forma a atender as necessidades das atuais gerações e permitir melhores condições de vida, sem comprometer a qualidade ambiental e o atendimento das necessidades das gerações futuras;

XIV - reciclagem: processo de transformação dos resíduos sólidos que envolve a alteração de suas propriedades físicas, físico-químicas ou biológicas, com vistas à transformação em insumos ou novos produtos, observadas as condições e os padrões estabelecidos pelos órgãos competentes do Sisnama e, se couber, do SNVS e do Suasa;

XV - rejeitos: resíduos sólidos que, depois de esgotadas todas as possibilidades de tratamento e recuperação por processos tecnológicos disponíveis e economicamente viáveis, não apresentem outra possibilidade que não a disposição final ambientalmente adequada;

XVI - resíduos sólidos: material, substância, objeto ou bem descartado resultante de atividades humanas em sociedade, a cuja destinação final se procede, se propõe proceder ou se está obrigado a proceder, nos estados sólido ou semissólido, bem como gases contidos em recipientes e líquidos cujas particularidades tornem inviável o seu lançamento na rede pública de esgotos ou em corpos d'água, ou exijam para isso soluções técnica ou economicamente inviáveis em face da melhor tecnologia disponível;

XVII - responsabilidade compartilhada pelo ciclo de vida dos produtos: conjunto de atribuições individualizadas e encadeadas dos fabricantes, importadores, distribuidores e comerciantes, dos consumidores e dos titulares dos serviços públicos de limpeza urbana e de manejo dos resíduos sólidos, para minimizar o volume de resíduos sólidos e rejeitos gerados, bem como para reduzir os impactos causados à saúde humana e à qualidade ambiental decorrentes do ciclo de vida dos produtos, nos termos desta Lei;

XVIII - reutilização: processo de aproveitamento dos resíduos sólidos sem sua transformação biológica, física ou físico-química, observadas as condições e os padrões estabelecidos pelos órgãos competentes do Sisnama e, se couber, do SNVS e do Suasa;

XIX - serviço público de limpeza urbana e de manejo de resíduos sólidos: conjunto de

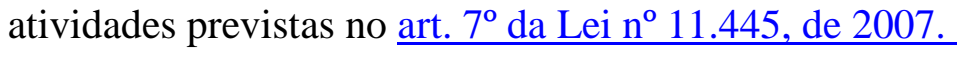

\section{TÍTULO II}

\section{DA POLÍTICA NACIONAL DE RESÍDUOS SÓLIDOS}

\section{CAPÍTULO I}

\section{DISPOSIÇÕES GERAIS}

Art. 4ํㅡ A Política Nacional de Resíduos Sólidos reúne o conjunto de princípios, objetivos, instrumentos, diretrizes, metas e ações adotados pelo Governo Federal, isoladamente ou em regime de cooperação com Estados, Distrito Federal, Municípios ou particulares, com vistas à gestão integrada e ao gerenciamento ambientalmente adequado dos resíduos sólidos.

Art. 5 A Política Nacional de Resíduos Sólidos integra a Política Nacional do Meio Ambiente e articula-se com a Política Nacional de Educação Ambiental, regulada pela Lei 


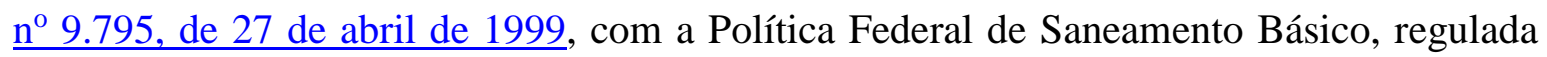
pela Lei n ${ }^{\circ} 11.445$, de 2007, e com a Lei ${ }^{0} 11.107$, de 6 de abril de 2005.

\section{CAPÍTULO II}

\section{DOS PRINCÍPIOS E OBJETIVOS}

Art. 60 São princípios da Política Nacional de Resíduos Sólidos:

I - a prevenção e a precaução;

II - o poluidor-pagador e o protetor-recebedor;

III - a visão sistêmica, na gestão dos resíduos sólidos, que considere as variáveis ambiental, social, cultural, econômica, tecnológica e de saúde pública;

IV - o desenvolvimento sustentável;

V - a ecoeficiência, mediante a compatibilização entre o fornecimento, a preços competitivos, de bens e serviços qualificados que satisfaçam as necessidades humanas e tragam qualidade de vida e a redução do impacto ambiental e do consumo de recursos naturais a um nível, no mínimo, equivalente à capacidade de sustentação estimada do planeta;

VI - a cooperação entre as diferentes esferas do poder público, o setor empresarial e demais segmentos da sociedade;

VII - a responsabilidade compartilhada pelo ciclo de vida dos produtos;

VIII - o reconhecimento do resíduo sólido reutilizável e reciclável como um bem econômico e de valor social, gerador de trabalho e renda e promotor de cidadania;

IX - o respeito às diversidades locais e regionais;

$\mathrm{X}$ - o direito da sociedade à informação e ao controle social;

XI - a razoabilidade e a proporcionalidade.

Art. 7º São objetivos da Política Nacional de Resíduos Sólidos:

I - proteção da saúde pública e da qualidade ambiental;

II - não geração, redução, reutilização, reciclagem e tratamento dos resíduos sólidos, bem como disposição final ambientalmente adequada dos rejeitos; serviços;

III - estímulo à adoção de padrões sustentáveis de produção e consumo de bens e

IV - adoção, desenvolvimento e aprimoramento de tecnologias limpas como forma de minimizar impactos ambientais;

V - redução do volume e da periculosidade dos resíduos perigosos; 
VI - incentivo à indústria da reciclagem, tendo em vista fomentar o uso de matériasprimas e insumos derivados de materiais recicláveis e reciclados;

VII - gestão integrada de resíduos sólidos;

VIII - articulação entre as diferentes esferas do poder público, e destas com o setor empresarial, com vistas à cooperação técnica e financeira para a gestão integrada de resíduos sólidos;

IX - capacitação técnica continuada na área de resíduos sólidos;

$X$ - regularidade, continuidade, funcionalidade e universalização da prestação dos serviços públicos de limpeza urbana e de manejo de resíduos sólidos, com adoção de mecanismos gerenciais e econômicos que assegurem a recuperação dos custos dos serviços prestados, como forma de garantir sua sustentabilidade operacional e financeira, observada a Lei ${ }^{\circ} 11.445$, de 2007;

XI - prioridade, nas aquisições e contratações governamentais, para:

a) produtos reciclados e recicláveis;

b) bens, serviços e obras que considerem critérios compatíveis com padrões de consumo social e ambientalmente sustentáveis;

XII - integração dos catadores de materiais reutilizáveis e recicláveis nas ações que envolvam a responsabilidade compartilhada pelo ciclo de vida dos produtos;

XIII - estímulo à implementação da avaliação do ciclo de vida do produto;

XIV - incentivo ao desenvolvimento de sistemas de gestão ambiental e empresarial voltados para a melhoria dos processos produtivos e ao reaproveitamento dos resíduos sólidos, incluídos a recuperação e o aproveitamento energético;

XV - estímulo à rotulagem ambiental e ao consumo sustentável.

\section{CAPÍTULO III}

\section{DOS INSTRUMENTOS}

Art. $8^{\circ}$ São instrumentos da Política Nacional de Resíduos Sólidos, entre outros:

I - os planos de resíduos sólidos;

II - os inventários e o sistema declaratório anual de resíduos sólidos;

III - a coleta seletiva, os sistemas de logística reversa e outras ferramentas relacionadas à implementação da responsabilidade compartilhada pelo ciclo de vida dos produtos;

IV - o incentivo à criação e ao desenvolvimento de cooperativas ou de outras formas de associação de catadores de materiais reutilizáveis e recicláveis;

V - o monitoramento e a fiscalização ambiental, sanitária e agropecuária; 
VI - a cooperação técnica e financeira entre os setores público e privado para o desenvolvimento de pesquisas de novos produtos, métodos, processos e tecnologias de gestão, reciclagem, reutilização, tratamento de resíduos e disposição final ambientalmente adequada de rejeitos;

VII - a pesquisa científica e tecnológica;

VIII - a educação ambiental;

IX - os incentivos fiscais, financeiros e creditícios;

X - o Fundo Nacional do Meio Ambiente e o Fundo Nacional de Desenvolvimento Científico e Tecnológico;

XI - o Sistema Nacional de Informações sobre a Gestão dos Resíduos Sólidos (Sinir);

XII - o Sistema Nacional de Informações em Saneamento Básico (Sinisa);

XIII - os conselhos de meio ambiente e, no que couber, os de saúde;

XIV - os órgãos colegiados municipais destinados ao controle social dos serviços de resíduos sólidos urbanos;

XV - o Cadastro Nacional de Operadores de Resíduos Perigosos;

XVI - os acordos setoriais;

XVII - no que couber, os instrumentos da Política Nacional de Meio Ambiente, entre eles: a) os padrões de qualidade ambiental;

b) o Cadastro Técnico Federal de Atividades Potencialmente Poluidoras ou Utilizadoras de Recursos Ambientais;

c) o Cadastro Técnico Federal de Atividades e Instrumentos de Defesa Ambiental;

d) a avaliação de impactos ambientais;

e) o Sistema Nacional de Informação sobre Meio Ambiente (Sinima);

f) o licenciamento e a revisão de atividades efetiva ou potencialmente poluidoras;

XVIII - os termos de compromisso e os termos de ajustamento de conduta; XIX - o incentivo à adoção de consórcios ou de outras formas de cooperação entre os entes federados, com vistas à elevação das escalas de aproveitamento e à redução dos custos envolvidos.

TÍTULO III

DAS DIRETRIZES APLICÁVEIS AOS RESÍDUOS SÓLIDOS

CAPÍTULO I

DISPOSIÇÕES PRELIMINARES 
Art. 9ำ Na gestão e gerenciamento de resíduos sólidos, deve ser observada a seguinte ordem de prioridade: não geração, redução, reutilização, reciclagem, tratamento dos resíduos sólidos e disposição final ambientalmente adequada dos rejeitos.

$\S 1^{\mathrm{o}}$ Poderão ser utilizadas tecnologias visando à recuperação energética dos resíduos sólidos urbanos, desde que tenha sido comprovada sua viabilidade técnica e ambiental e com a implantação de programa de monitoramento de emissão de gases tóxicos aprovado pelo órgão ambiental.

$\S 2^{\circ}$ A Política Nacional de Resíduos Sólidos e as Políticas de Resíduos Sólidos dos Estados, do Distrito Federal e dos Municípios serão compatíveis com o disposto no caput e no $\S 1^{\circ}$ deste artigo e com as demais diretrizes estabelecidas nesta Lei.

Art. 10. Incumbe ao Distrito Federal e aos Municípios a gestão integrada dos resíduos sólidos gerados nos respectivos territórios, sem prejuízo das competências de controle e fiscalização dos órgãos federais e estaduais do Sisnama, do SNVS e do Suasa, bem como da responsabilidade do gerador pelo gerenciamento de resíduos, consoante o estabelecido nesta Lei.

Art. 11. Observadas as diretrizes e demais determinações estabelecidas nesta Lei e em seu regulamento, incumbe aos Estados:

I - promover a integração da organização, do planejamento e da execução das funções públicas de interesse comum relacionadas à gestão dos resíduos sólidos nas regiões metropolitanas, aglomerações urbanas e microrregiões, nos termos da lei complementar estadual prevista no $\S 3^{\circ}$ do art. 25 da Constituiç̧ão Federal;

II - controlar e fiscalizar as atividades dos geradores sujeitas a licenciamento ambiental pelo órgão estadual do Sisnama.

Parágrafo único. A atuação do Estado na forma do caput deve apoiar e priorizar as iniciativas do Município de soluções consorciadas ou compartilhadas entre 2 (dois) ou mais Municípios.

Art. 12. A União, os Estados, o Distrito Federal e os Municípios organizarão e manterão, de forma conjunta, o Sistema Nacional de Informações sobre a Gestão dos Resíduos Sólidos (Sinir), articulado com o Sinisa e o Sinima.

Parágrafo único. Incumbe aos Estados, ao Distrito Federal e aos Municípios fornecer ao órgão federal responsável pela coordenação do Sinir todas as informações necessárias sobre os resíduos sob sua esfera de competência, na forma e na periodicidade estabelecidas em regulamento.

Art. 13. Para os efeitos desta Lei, os resíduos sólidos têm a seguinte classificação:

I - quanto à origem:

a) resíduos domiciliares: os originários de atividades domésticas em residências urbanas;

b) resíduos de limpeza urbana: os originários da varrição, limpeza de logradouros e vias públicas e outros serviços de limpeza urbana; 
c) resíduos sólidos urbanos: os englobados nas alíneas "a" e "b";

d) resíduos de estabelecimentos comerciais e prestadores de serviços: os gerados nessas atividades, excetuados os referidos nas alíneas "b", "e", "g", "h" e “j”;

e) resíduos dos serviços públicos de saneamento básico: os gerados nessas atividades, excetuados os referidos na alínea "c";

f) resíduos industriais: os gerados nos processos produtivos e instalações industriais;

g) resíduos de serviços de saúde: os gerados nos serviços de saúde, conforme definido em regulamento ou em normas estabelecidas pelos órgãos do Sisnama e do SNVS;

h) resíduos da construção civil: os gerados nas construções, reformas, reparos e demolições de obras de construção civil, incluídos os resultantes da preparação e escavação de terrenos para obras civis;

i) resíduos agrossilvopastoris: os gerados nas atividades agropecuárias e silviculturais, incluídos os relacionados a insumos utilizados nessas atividades;

j) resíduos de serviços de transportes: os originários de portos, aeroportos, terminais alfandegários, rodoviários e ferroviários e passagens de fronteira;

k) resíduos de mineração: os gerados na atividade de pesquisa, extração ou beneficiamento de minérios;

II - quanto à periculosidade:

a) resíduos perigosos: aqueles que, em razão de suas características de inflamabilidade, corrosividade, reatividade, toxicidade, patogenicidade, carcinogenicidade, teratogenicidade e mutagenicidade, apresentam significativo risco à saúde pública ou à qualidade ambiental, de acordo com lei, regulamento ou norma técnica;

b) resíduos não perigosos: aqueles não enquadrados na alínea "a".

Parágrafo único. Respeitado o disposto no art. 20, os resíduos referidos na alínea "d" do inciso I do caput, se caracterizados como não perigosos, podem, em razão de sua natureza, composição ou volume, ser equiparados aos resíduos domiciliares pelo poder público municipal.

\section{CAPÍTULO II}

\section{DOS PLANOS DE RESÍDUOS SÓLIDOS}

\section{Seção I}

Disposições Gerais

Art. 14. São planos de resíduos sólidos:

I - o Plano Nacional de Resíduos Sólidos;

II - os planos estaduais de resíduos sólidos; 
III - os planos microrregionais de resíduos sólidos e os planos de resíduos sólidos de regiões metropolitanas ou aglomerações urbanas;

IV - os planos intermunicipais de resíduos sólidos;

V - os planos municipais de gestão integrada de resíduos sólidos;

VI - os planos de gerenciamento de resíduos sólidos.

Parágrafo único. É assegurada ampla publicidade ao conteúdo dos planos de resíduos sólidos, bem como controle social em sua formulação, implementação e operacionalização, observado o disposto na Lei $\mathrm{n}^{0} 10.650$, de 16 de abril de 2003 , e no art. 47 da Lei $\mathrm{n}^{\circ}$ $\underline{11.445, \text { de } 2007 .}$

\section{Seção II}

Do Plano Nacional de Resíduos Sólidos

Art. 15. A União elaborará, sob a coordenação do Ministério do Meio Ambiente, o Plano Nacional de Resíduos Sólidos, com vigência por prazo indeterminado e horizonte de 20 (vinte) anos, a ser atualizado a cada 4 (quatro) anos, tendo como conteúdo mínimo:

I - diagnóstico da situação atual dos resíduos sólidos;

II - proposição de cenários, incluindo tendências internacionais e macroeconômicas;

III - metas de redução, reutilização, reciclagem, entre outras, com vistas a reduzir a quantidade de resíduos e rejeitos encaminhados para disposição final ambientalmente adequada;

IV - metas para o aproveitamento energético dos gases gerados nas unidades de disposição final de resíduos sólidos;

V - metas para a eliminação e recuperação de lixões, associadas à inclusão social e à emancipação econômica de catadores de materiais reutilizáveis e recicláveis;

VI - programas, projetos e ações para o atendimento das metas previstas;

VII - normas e condicionantes técnicas para o acesso a recursos da União, para a obtenção de seu aval ou para o acesso a recursos administrados, direta ou indiretamente, por entidade federal, quando destinados a ações e programas de interesse dos resíduos sólidos; sólidos;

VIII - medidas para incentivar e viabilizar a gestão regionalizada dos resíduos

IX - diretrizes para o planejamento e demais atividades de gestão de resíduos sólidos das regiões integradas de desenvolvimento instituídas por lei complementar, bem como para as áreas de especial interesse turístico;

$\mathrm{X}$ - normas e diretrizes para a disposição final de rejeitos e, quando couber, de resíduos; 
XI - meios a serem utilizados para o controle e a fiscalização, no âmbito nacional, de sua implementação e operacionalização, assegurado o controle social.

Parágrafo único. O Plano Nacional de Resíduos Sólidos será elaborado mediante processo de mobilização e participação social, incluindo a realização de audiências e consultas públicas.

\section{Seção III}

\section{Dos Planos Estaduais de Resíduos Sólidos}

Art. 16. A elaboração de plano estadual de resíduos sólidos, nos termos previstos por esta Lei, é condição para os Estados terem acesso a recursos da União, ou por ela controlados, destinados a empreendimentos e serviços relacionados à gestão de resíduos sólidos, ou para serem beneficiados por incentivos ou financiamentos de entidades federais de crédito ou fomento para tal finalidade. (Vigência)

$\S 1^{0}$ Serão priorizados no acesso aos recursos da União referidos no caput os Estados que instituírem microrregiões, consoante o $\S 3^{\circ}$ do art. 25 da Constituição Federal, para integrar a organização, o planejamento e a execução das ações a cargo de Municípios limítrofes na gestão dos resíduos sólidos.

$\S 2^{\mathrm{o}}$ Serão estabelecidas em regulamento normas complementares sobre o acesso aos recursos da União na forma deste artigo.

$\S 3^{\text {o }}$ Respeitada a responsabilidade dos geradores nos termos desta Lei, as microrregiões instituídas conforme previsto no $\S 1^{\circ}$ abrangem atividades de coleta seletiva, recuperação e reciclagem, tratamento e destinação final dos resíduos sólidos urbanos, a gestão de resíduos de construção civil, de serviços de transporte, de serviços de saúde, agrossilvopastoris ou outros resíduos, de acordo com as peculiaridades microrregionais.

Art. 17. O plano estadual de resíduos sólidos será elaborado para vigência por prazo indeterminado, abrangendo todo o território do Estado, com horizonte de atuação de 20 (vinte) anos e revisões a cada 4 (quatro) anos, e tendo como conteúdo mínimo:

I - diagnóstico, incluída a identificação dos principais fluxos de resíduos no Estado e seus impactos socioeconômicos e ambientais;

II - proposição de cenários;

III - metas de redução, reutilização, reciclagem, entre outras, com vistas a reduzir a quantidade de resíduos e rejeitos encaminhados para disposição final ambientalmente adequada;

IV - metas para o aproveitamento energético dos gases gerados nas unidades de disposição final de resíduos sólidos;

V - metas para a eliminação e recuperação de lixões, associadas à inclusão social e à emancipação econômica de catadores de materiais reutilizáveis e recicláveis;

VI - programas, projetos e ações para o atendimento das metas previstas; 
VII - normas e condicionantes técnicas para o acesso a recursos do Estado, para a obtenção de seu aval ou para o acesso de recursos administrados, direta ou indiretamente, por entidade estadual, quando destinados às ações e programas de interesse dos resíduos sólidos;

VIII - medidas para incentivar e viabilizar a gestão consorciada ou compartilhada dos resíduos sólidos;

IX - diretrizes para o planejamento e demais atividades de gestão de resíduos sólidos de regiões metropolitanas, aglomerações urbanas e microrregiões;

$\mathrm{X}$ - normas e diretrizes para a disposição final de rejeitos e, quando couber, de resíduos, respeitadas as disposições estabelecidas em âmbito nacional;

XI - previsão, em conformidade com os demais instrumentos de planejamento territorial, especialmente o zoneamento ecológico-econômico e o zoneamento costeiro, de:

a) zonas favoráveis para a localização de unidades de tratamento de resíduos sólidos ou de disposição final de rejeitos;

b) áreas degradadas em razão de disposição inadequada de resíduos sólidos ou rejeitos a serem objeto de recuperação ambiental;

XII - meios a serem utilizados para o controle e a fiscalização, no âmbito estadual, de sua implementação e operacionalização, assegurado o controle social.

$\S 1$ 1ํ Além do plano estadual de resíduos sólidos, os Estados poderão elaborar planos microrregionais de resíduos sólidos, bem como planos específicos direcionados às regiões metropolitanas ou às aglomerações urbanas.

$\S 2^{\circ}$ A elaboração e a implementação pelos Estados de planos microrregionais de resíduos sólidos, ou de planos de regiões metropolitanas ou aglomerações urbanas, em consonância com o previsto no $\S 1$, , dar-se-ão obrigatoriamente com a participação dos Municípios envolvidos e não excluem nem substituem qualquer das prerrogativas a cargo dos Municípios previstas por esta Lei.

$\S 3^{\mathrm{o}}$ Respeitada a responsabilidade dos geradores nos termos desta Lei, o plano microrregional de resíduos sólidos deve atender ao previsto para o plano estadual e estabelecer soluções integradas para a coleta seletiva, a recuperação e a reciclagem, o tratamento e a destinação final dos resíduos sólidos urbanos e, consideradas as peculiaridades microrregionais, outros tipos de resíduos.

\section{Seção IV}

\section{Dos Planos Municipais de Gestão Integrada de Resíduos Sólidos}

Art. 18. A elaboração de plano municipal de gestão integrada de resíduos sólidos, nos termos previstos por esta Lei, é condição para o Distrito Federal e os Municípios terem acesso a recursos da União, ou por ela controlados, destinados a empreendimentos e serviços relacionados à limpeza urbana e ao manejo de resíduos sólidos, ou para serem beneficiados por incentivos ou financiamentos de entidades federais de crédito ou fomento para tal finalidade. (Vigência) 
$\S 1^{\mathrm{o}}$ Serão priorizados no acesso aos recursos da União referidos no caput os Municípios que:

I - optarem por soluções consorciadas intermunicipais para a gestão dos resíduos sólidos, incluída a elaboração e implementação de plano intermunicipal, ou que se inserirem de forma voluntária nos planos microrregionais de resíduos sólidos referidos no $\S 1^{\mathrm{o}}$ do art. 16;

II - implantarem a coleta seletiva com a participação de cooperativas ou outras formas de associação de catadores de materiais reutilizáveis e recicláveis formadas por pessoas físicas de baixa renda.

$\S 2^{o}$ Serão estabelecidas em regulamento normas complementares sobre o acesso aos recursos da União na forma deste artigo.

Art. 19. O plano municipal de gestão integrada de resíduos sólidos tem o seguinte conteúdo mínimo:

I - diagnóstico da situação dos resíduos sólidos gerados no respectivo território, contendo a origem, o volume, a caracterização dos resíduos e as formas de destinação e disposição final adotadas;

II - identificação de áreas favoráveis para disposição final ambientalmente adequada de rejeitos, observado o plano diretor de que trata o $\S 1^{\circ}$ do art. 182 da Constituição Federal e o zoneamento ambiental, se houver;

III - identificação das possibilidades de implantação de soluções consorciadas ou compartilhadas com outros Municípios, considerando, nos critérios de economia de escala, a proximidade dos locais estabelecidos e as formas de prevenção dos riscos ambientais;

IV - identificação dos resíduos sólidos e dos geradores sujeitos a plano de gerenciamento específico nos termos do art. 20 ou a sistema de logística reversa na forma do art. 33, observadas as disposições desta Lei e de seu regulamento, bem como as normas estabelecidas pelos órgãos do Sisnama e do SNVS;

V - procedimentos operacionais e especificações mínimas a serem adotados nos serviços públicos de limpeza urbana e de manejo de resíduos sólidos, incluída a disposição final ambientalmente adequada dos rejeitos e observada a Lei no 11.445, de 2007;

VI - indicadores de desempenho operacional e ambiental dos serviços públicos de limpeza urbana e de manejo de resíduos sólidos;

VII - regras para o transporte e outras etapas do gerenciamento de resíduos sólidos de que trata o art. 20, observadas as normas estabelecidas pelos órgãos do Sisnama e do SNVS e demais disposições pertinentes da legislação federal e estadual;

VIII - definição das responsabilidades quanto à sua implementação e operacionalização, incluídas as etapas do plano de gerenciamento de resíduos sólidos a que se refere o art. 20 a cargo do poder público;

IX - programas e ações de capacitação técnica voltados para sua implementação e operacionalização; 
$\mathrm{X}$ - programas e ações de educação ambiental que promovam a não geração, a redução, a reutilização e a reciclagem de resíduos sólidos;

XI - programas e ações para a participação dos grupos interessados, em especial das cooperativas ou outras formas de associação de catadores de materiais reutilizáveis e recicláveis formadas por pessoas físicas de baixa renda, se houver;

XII - mecanismos para a criação de fontes de negócios, emprego e renda, mediante a valorização dos resíduos sólidos;

XIII - sistema de cálculo dos custos da prestação dos serviços públicos de limpeza urbana e de manejo de resíduos sólidos, bem como a forma de cobrança desses serviços, observada a Lei ${ }^{\circ} 11.445$, de 2007;

XIV - metas de redução, reutilização, coleta seletiva e reciclagem, entre outras, com vistas a reduzir a quantidade de rejeitos encaminhados para disposição final ambientalmente adequada;

XV - descrição das formas e dos limites da participação do poder público local na coleta seletiva e na logística reversa, respeitado o disposto no art. 33, e de outras ações relativas à responsabilidade compartilhada pelo ciclo de vida dos produtos;

XVI - meios a serem utilizados para o controle e a fiscalização, no âmbito local, da implementação e operacionalização dos planos de gerenciamento de resíduos sólidos de que trata o art. 20 e dos sistemas de logística reversa previstos no art. 33;

XVII - ações preventivas e corretivas a serem praticadas, incluindo programa de monitoramento;

XVIII - identificação dos passivos ambientais relacionados aos resíduos sólidos, incluindo áreas contaminadas, e respectivas medidas saneadoras;

XIX - periodicidade de sua revisão, observado prioritariamente o período de vigência do plano plurianual municipal.

$\S 1^{\text {o }}$ O plano municipal de gestão integrada de resíduos sólidos pode estar inserido no plano de saneamento básico previsto no art. 19 da Lei $\mathrm{n}^{\circ} 11.445$, de 2007, respeitado o conteúdo mínimo previsto nos incisos do caput e observado o disposto no $\S 2^{\underline{o}}$, todos deste artigo.

$\S 2^{\text {o }}$ Para Municípios com menos de 20.000 (vinte mil) habitantes, o plano municipal de gestão integrada de resíduos sólidos terá conteúdo simplificado, na forma do regulamento.

$\S 3^{\mathrm{o}} \mathrm{O}$ disposto no $\S 2^{\mathrm{o}}$ não se aplica a Municípios:

I - integrantes de áreas de especial interesse turístico;

II - inseridos na área de influência de empreendimentos ou atividades com significativo impacto ambiental de âmbito regional ou nacional;

III - cujo território abranja, total ou parcialmente, Unidades de Conservação. 
§ 4ํำ A existência de plano municipal de gestão integrada de resíduos sólidos não exime o Município ou o Distrito Federal do licenciamento ambiental de aterros sanitários e de outras infraestruturas e instalações operacionais integrantes do serviço público de limpeza urbana e de manejo de resíduos sólidos pelo órgão competente do Sisnama.

$\S 5^{\circ}$ Na definição de responsabilidades na forma do inciso VIII do caput deste artigo, é vedado atribuir ao serviço público de limpeza urbana e de manejo de resíduos sólidos a realização de etapas do gerenciamento dos resíduos a que se refere o art. 20 em desacordo com a respectiva licença ambiental ou com normas estabelecidas pelos órgãos do Sisnama e, se couber, do SNVS.

$\S 6^{\mathrm{o}}$ Além do disposto nos incisos I a XIX do caput deste artigo, o plano municipal de gestão integrada de resíduos sólidos contemplará ações específicas a serem desenvolvidas no âmbito dos órgãos da administração pública, com vistas à utilização racional dos recursos ambientais, ao combate a todas as formas de desperdício e à minimização da geração de resíduos sólidos.

§ 7ํ O conteúdo do plano municipal de gestão integrada de resíduos sólidos será disponibilizado para o Sinir, na forma do regulamento.

$\S 8^{\circ}$ A inexistência do plano municipal de gestão integrada de resíduos sólidos não pode ser utilizada para impedir a instalação ou a operação de empreendimentos ou atividades devidamente licenciados pelos órgãos competentes.

$\S 9^{o}$ Nos termos do regulamento, o Município que optar por soluções consorciadas intermunicipais para a gestão dos resíduos sólidos, assegurado que o plano intermunicipal preencha os requisitos estabelecidos nos incisos I a XIX do caput deste artigo, pode ser dispensado da elaboração de plano municipal de gestão integrada de resíduos sólidos.

\section{Seção V}

Do Plano de Gerenciamento de Resíduos Sólidos

Art. 20. Estão sujeitos à elaboração de plano de gerenciamento de resíduos sólidos:

I - os geradores de resíduos sólidos previstos nas alíneas "e", "f", "g” e "k" do inciso I do art. 13;

II - os estabelecimentos comerciais e de prestação de serviços que:

a) gerem resíduos perigosos;

b) gerem resíduos que, mesmo caracterizados como não perigosos, por sua natureza, composição ou volume, não sejam equiparados aos resíduos domiciliares pelo poder público municipal;

III - as empresas de construção civil, nos termos do regulamento ou de normas estabelecidas pelos órgãos do Sisnama;

IV - os responsáveis pelos terminais e outras instalações referidas na alínea "j” do inciso I do art. 13 e, nos termos do regulamento ou de normas estabelecidas pelos órgãos do Sisnama e, se couber, do SNVS, as empresas de transporte; 
V - os responsáveis por atividades agrossilvopastoris, se exigido pelo órgão competente do Sisnama, do SNVS ou do Suasa.

Parágrafo único. Observado o disposto no Capítulo IV deste Título, serão estabelecidas por regulamento exigências específicas relativas ao plano de gerenciamento de resíduos perigosos. mínimo:

Art. 21. O plano de gerenciamento de resíduos sólidos tem o seguinte conteúdo

I - descrição do empreendimento ou atividade;

II - diagnóstico dos resíduos sólidos gerados ou administrados, contendo a origem, o volume e a caracterização dos resíduos, incluindo os passivos ambientais a eles relacionados;

III - observadas as normas estabelecidas pelos órgãos do Sisnama, do SNVS e do Suasa e, se houver, o plano municipal de gestão integrada de resíduos sólidos:

a) explicitação dos responsáveis por cada etapa do gerenciamento de resíduos sólidos;

b) definição dos procedimentos operacionais relativos às etapas do gerenciamento de resíduos sólidos sob responsabilidade do gerador;

IV - identificação das soluções consorciadas ou compartilhadas com outros geradores;

$\mathrm{V}$ - ações preventivas e corretivas a serem executadas em situações de gerenciamento incorreto ou acidentes;

VI - metas e procedimentos relacionados à minimização da geração de resíduos sólidos e, observadas as normas estabelecidas pelos órgãos do Sisnama, do SNVS e do Suasa, à reutilização e reciclagem;

VII - se couber, ações relativas à responsabilidade compartilhada pelo ciclo de vida dos produtos, na forma do art. 31 ;

VIII - medidas saneadoras dos passivos ambientais relacionados aos resíduos sólidos;

IX - periodicidade de sua revisão, observado, se couber, o prazo de vigência da respectiva licença de operação a cargo dos órgãos do Sisnama.

$\S 1^{\mathrm{o}}$ O plano de gerenciamento de resíduos sólidos atenderá ao disposto no plano municipal de gestão integrada de resíduos sólidos do respectivo Município, sem prejuízo das normas estabelecidas pelos órgãos do Sisnama, do SNVS e do Suasa.

$\S 2^{\mathrm{o}}$ A inexistência do plano municipal de gestão integrada de resíduos sólidos não obsta a elaboração, a implementação ou a operacionalização do plano de gerenciamento de resíduos sólidos.

§ 3ำ Serão estabelecidos em regulamento: 
I - normas sobre a exigibilidade e o conteúdo do plano de gerenciamento de resíduos sólidos relativo à atuação de cooperativas ou de outras formas de associação de catadores de materiais reutilizáveis e recicláveis;

II - critérios e procedimentos simplificados para apresentação dos planos de gerenciamento de resíduos sólidos para microempresas e empresas de pequeno porte, assim consideradas as definidas nos incisos I e II do art. $3^{\circ}$ da Lei Complementar $\mathrm{n}^{\circ} 123$, de 14 de dezembro de 2006, desde que as atividades por elas desenvolvidas não gerem resíduos perigosos.

Art. 22. Para a elaboração, implementação, operacionalização e monitoramento de todas as etapas do plano de gerenciamento de resíduos sólidos, nelas incluído o controle da disposição final ambientalmente adequada dos rejeitos, será designado responsável técnico devidamente habilitado.

Art. 23. Os responsáveis por plano de gerenciamento de resíduos sólidos manterão atualizadas e disponíveis ao órgão municipal competente, ao órgão licenciador do Sisnama e a outras autoridades, informações completas sobre a implementação e a operacionalização do plano sob sua responsabilidade.

$\S 1^{\text {o }}$ Para a consecução do disposto no caput, sem prejuízo de outras exigências cabíveis por parte das autoridades, será implementado sistema declaratório com periodicidade, no mínimo, anual, na forma do regulamento.

$\S 2^{\underline{0}}$ As informações referidas no caput serão repassadas pelos órgãos públicos ao Sinir, na forma do regulamento.

Art. 24. O plano de gerenciamento de resíduos sólidos é parte integrante do processo de licenciamento ambiental do empreendimento ou atividade pelo órgão competente do Sisnama.

$\S 1^{\mathrm{o}}$ Nos empreendimentos e atividades não sujeitos a licenciamento ambiental, a aprovação do plano de gerenciamento de resíduos sólidos cabe à autoridade municipal competente.

$\S 2^{\mathrm{o}}$ No processo de licenciamento ambiental referido no $\S 1^{\mathrm{o}}$ a cargo de órgão federal ou estadual do Sisnama, será assegurada oitiva do órgão municipal competente, em especial quanto à disposição final ambientalmente adequada de rejeitos.

\section{CAPÍTULO III}

\section{DAS RESPONSABILIDADES DOS GERADORES E DO PODER PÚBLICO}

\section{Seção I}

\section{Disposições Gerais}

Art. 25. O poder público, o setor empresarial e a coletividade são responsáveis pela efetividade das ações voltadas para assegurar a observância da Política Nacional de Resíduos Sólidos e das diretrizes e demais determinações estabelecidas nesta Lei e em seu regulamento. 
Art. 26. O titular dos serviços públicos de limpeza urbana e de manejo de resíduos sólidos é responsável pela organização e prestação direta ou indireta desses serviços, observados o respectivo plano municipal de gestão integrada de resíduos sólidos, a Lei $\mathrm{n}^{\circ}$ 11.445 , de 2007, e as disposições desta Lei e seu regulamento.

Art. 27. As pessoas físicas ou jurídicas referidas no art. 20 são responsáveis pela implementação e operacionalização integral do plano de gerenciamento de resíduos sólidos aprovado pelo órgão competente na forma do art. 24.

$\S 1^{\underline{o}}$ A contratação de serviços de coleta, armazenamento, transporte, transbordo, tratamento ou destinação final de resíduos sólidos, ou de disposição final de rejeitos, não isenta as pessoas físicas ou jurídicas referidas no art. 20 da responsabilidade por danos que vierem a ser provocados pelo gerenciamento inadequado dos respectivos resíduos ou rejeitos.

$\S 2^{\underline{0}}$ Nos casos abrangidos pelo art. 20, as etapas sob responsabilidade do gerador que forem realizadas pelo poder público serão devidamente remuneradas pelas pessoas físicas ou jurídicas responsáveis, observado o disposto no $§ 5^{\circ}$ do art. 19.

Art. 28. O gerador de resíduos sólidos domiciliares tem cessada sua responsabilidade pelos resíduos com a disponibilização adequada para a coleta ou, nos casos abrangidos pelo art. 33, com a devolução.

Art. 29. Cabe ao poder público atuar, subsidiariamente, com vistas a minimizar ou cessar o dano, logo que tome conhecimento de evento lesivo ao meio ambiente ou à saúde pública relacionado ao gerenciamento de resíduos sólidos.

Parágrafo único. Os responsáveis pelo dano ressarcirão integralmente o poder público pelos gastos decorrentes das ações empreendidas na forma do caput.

\section{Seção II}

Da Responsabilidade Compartilhada

Art. 30. É instituída a responsabilidade compartilhada pelo ciclo de vida dos produtos, a ser implementada de forma individualizada e encadeada, abrangendo os fabricantes, importadores, distribuidores e comerciantes, os consumidores e os titulares dos serviços públicos de limpeza urbana e de manejo de resíduos sólidos, consoante as atribuições e procedimentos previstos nesta Seção.

Parágrafo único. A responsabilidade compartilhada pelo ciclo de vida dos produtos tem por objetivo:

I - compatibilizar interesses entre os agentes econômicos e sociais e os processos de gestão empresarial e mercadológica com os de gestão ambiental, desenvolvendo estratégias sustentáveis;

II - promover o aproveitamento de resíduos sólidos, direcionando-os para a sua cadeia produtiva ou para outras cadeias produtivas;

III - reduzir a geração de resíduos sólidos, o desperdício de materiais, a poluição e os danos ambientais; 
IV - incentivar a utilização de insumos de menor agressividade ao meio ambiente e de maior sustentabilidade;

$\mathrm{V}$ - estimular o desenvolvimento de mercado, a produção e o consumo de produtos derivados de materiais reciclados e recicláveis;

VI - propiciar que as atividades produtivas alcancem eficiência e sustentabilidade;

VII - incentivar as boas práticas de responsabilidade socioambiental.

Art. 31. Sem prejuízo das obrigações estabelecidas no plano de gerenciamento de resíduos sólidos e com vistas a fortalecer a responsabilidade compartilhada e seus objetivos, os fabricantes, importadores, distribuidores e comerciantes têm responsabilidade que abrange: produtos:

I - investimento no desenvolvimento, na fabricação e na colocação no mercado de

a) que sejam aptos, após o uso pelo consumidor, à reutilização, à reciclagem ou a outra forma de destinação ambientalmente adequada;

b) cuja fabricação e uso gerem a menor quantidade de resíduos sólidos possível;

II - divulgação de informações relativas às formas de evitar, reciclar e eliminar os resíduos sólidos associados a seus respectivos produtos;

III - recolhimento dos produtos e dos resíduos remanescentes após o uso, assim como sua subsequente destinação final ambientalmente adequada, no caso de produtos objeto de sistema de logística reversa na forma do art. 33;

IV - compromisso de, quando firmados acordos ou termos de compromisso com o Município, participar das ações previstas no plano municipal de gestão integrada de resíduos sólidos, no caso de produtos ainda não inclusos no sistema de logística reversa.

Art. 32. As embalagens devem ser fabricadas com materiais que propiciem a reutilização ou a reciclagem.

$\S 1$ 을 Cabe aos respectivos responsáveis assegurar que as embalagens sejam:

I - restritas em volume e peso às dimensões requeridas à proteção do conteúdo e à comercialização do produto;

II - projetadas de forma a serem reutilizadas de maneira tecnicamente viável e compatível com as exigências aplicáveis ao produto que contêm;

III - recicladas, se a reutilização não for possível.

$\S 2^{\underline{0}}$ O regulamento disporá sobre os casos em que, por razões de ordem técnica ou econômica, não seja viável a aplicação do disposto no caput.

$\S 3^{\circ}$ É responsável pelo atendimento do disposto neste artigo todo aquele que:

I - manufatura embalagens ou fornece materiais para a fabricação de embalagens; 
II - coloca em circulação embalagens, materiais para a fabricação de embalagens ou produtos embalados, em qualquer fase da cadeia de comércio.

Art. 33. São obrigados a estruturar e implementar sistemas de logística reversa, mediante retorno dos produtos após o uso pelo consumidor, de forma independente do serviço público de limpeza urbana e de manejo dos resíduos sólidos, os fabricantes, importadores, distribuidores e comerciantes de: $\quad \underline{\text { (Regulamento) }}$

I - agrotóxicos, seus resíduos e embalagens, assim como outros produtos cuja embalagem, após o uso, constitua resíduo perigoso, observadas as regras de gerenciamento de resíduos perigosos previstas em lei ou regulamento, em normas estabelecidas pelos órgãos do Sisnama, do SNVS e do Suasa, ou em normas técnicas;

II - pilhas e baterias;

III - pneus;

IV - óleos lubrificantes, seus resíduos e embalagens;

V - lâmpadas fluorescentes, de vapor de sódio e mercúrio e de luz mista;

VI - produtos eletroeletrônicos e seus componentes.

$\S 1^{\mathrm{o}} \mathrm{Na}$ forma do disposto em regulamento ou em acordos setoriais e termos de compromisso firmados entre o poder público e o setor empresarial, os sistemas previstos no caput serão estendidos a produtos comercializados em embalagens plásticas, metálicas ou de vidro, e aos demais produtos e embalagens, considerando, prioritariamente, o grau e a extensão do impacto à saúde pública e ao meio ambiente dos resíduos gerados.

$\S 2^{\circ}$ A definição dos produtos e embalagens a que se refere o $\S 1^{\circ}$ considerará a viabilidade técnica e econômica da logística reversa, bem como o grau e a extensão do impacto à saúde pública e ao meio ambiente dos resíduos gerados.

$\S 3^{\text {o }}$ Sem prejuízo de exigências específicas fixadas em lei ou regulamento, em normas estabelecidas pelos órgãos do Sisnama e do SNVS, ou em acordos setoriais e termos de compromisso firmados entre o poder público e o setor empresarial, cabe aos fabricantes, importadores, distribuidores e comerciantes dos produtos a que se referem os incisos II, III, V e VI ou dos produtos e embalagens a que se referem os incisos I e IV do caput e o $\S 1^{\mathrm{o}}$ tomar todas as medidas necessárias para assegurar a implementação e operacionalização do sistema de logística reversa sob seu encargo, consoante o estabelecido neste artigo, podendo, entre outras medidas:

I - implantar procedimentos de compra de produtos ou embalagens usados;

II - disponibilizar postos de entrega de resíduos reutilizáveis e recicláveis;

III - atuar em parceria com cooperativas ou outras formas de associação de catadores de materiais reutilizáveis e recicláveis, nos casos de que trata o $\S 1$ ㅇ․

$\S 4^{\circ}$ Os consumidores deverão efetuar a devolução após o uso, aos comerciantes ou distribuidores, dos produtos e das embalagens a que se referem os incisos I a VI do caput, e de outros produtos ou embalagens objeto de logística reversa, na forma do $\S 1 \stackrel{\circ}{\circ}$. 
§ 5ำ Os comerciantes e distribuidores deverão efetuar a devolução aos fabricantes ou aos importadores dos produtos e embalagens reunidos ou devolvidos na forma dos $\S \S 3^{\mathrm{o}} \mathrm{e}$ $4^{\circ}$.

$\S 6^{0}$ Os fabricantes e os importadores darão destinação ambientalmente adequada aos produtos e às embalagens reunidos ou devolvidos, sendo o rejeito encaminhado para a disposição final ambientalmente adequada, na forma estabelecida pelo órgão competente do Sisnama e, se houver, pelo plano municipal de gestão integrada de resíduos sólidos.

$\S$ 7ํ Se o titular do serviço público de limpeza urbana e de manejo de resíduos sólidos, por acordo setorial ou termo de compromisso firmado com o setor empresarial, encarregar-se de atividades de responsabilidade dos fabricantes, importadores, distribuidores e comerciantes nos sistemas de logística reversa dos produtos e embalagens a que se refere este artigo, as ações do poder público serão devidamente remuneradas, na forma previamente acordada entre as partes.

$\S 8^{0}$ Com exceção dos consumidores, todos os participantes dos sistemas de logística reversa manterão atualizadas e disponíveis ao órgão municipal competente e a outras autoridades informações completas sobre a realização das ações sob sua responsabilidade.

Art. 34. Os acordos setoriais ou termos de compromisso referidos no inciso IV do caput do art. 31 e no $\S 1^{\circ}$ do art. 33 podem ter abrangência nacional, regional, estadual ou municipal.

$\S 1^{\mathrm{o}}$ Os acordos setoriais e termos de compromisso firmados em âmbito nacional têm prevalência sobre os firmados em âmbito regional ou estadual, e estes sobre os firmados em âmbito municipal.

(Vide Decreto $n^{\circ} 9.177$, de 2017)

$\S 2^{\underline{0}} \mathrm{Na}$ aplicação de regras concorrentes consoante o $\S 1^{\mathrm{o}}$, os acordos firmados com menor abrangência geográfica podem ampliar, mas não abrandar, as medidas de proteção ambiental constantes nos acordos setoriais e termos de compromisso firmados com maior abrangência geográfica. $\quad$ (Vide Decreto ${ }^{\circ}$ 9.177, de 2017)

Art. 35. Sempre que estabelecido sistema de coleta seletiva pelo plano municipal de gestão integrada de resíduos sólidos e na aplicação do art. 33, os consumidores são obrigados a:

I - acondicionar adequadamente e de forma diferenciada os resíduos sólidos gerados;

II - disponibilizar adequadamente os resíduos sólidos reutilizáveis e recicláveis para coleta ou devolução.

Parágrafo único. O poder público municipal pode instituir incentivos econômicos aos consumidores que participam do sistema de coleta seletiva referido no caput, na forma de lei municipal.

Art. 36. No âmbito da responsabilidade compartilhada pelo ciclo de vida dos produtos, cabe ao titular dos serviços públicos de limpeza urbana e de manejo de resíduos sólidos, observado, se houver, o plano municipal de gestão integrada de resíduos sólidos: 
I - adotar procedimentos para reaproveitar os resíduos sólidos reutilizáveis e recicláveis oriundos dos serviços públicos de limpeza urbana e de manejo de resíduos sólidos;

II - estabelecer sistema de coleta seletiva;

III - articular com os agentes econômicos e sociais medidas para viabilizar o retorno ao ciclo produtivo dos resíduos sólidos reutilizáveis e recicláveis oriundos dos serviços de limpeza urbana e de manejo de resíduos sólidos;

IV - realizar as atividades definidas por acordo setorial ou termo de compromisso na forma do $\S 7^{\circ}$ do art. 33, mediante a devida remuneração pelo setor empresarial;

V - implantar sistema de compostagem para resíduos sólidos orgânicos e articular com os agentes econômicos e sociais formas de utilização do composto produzido;

VI - dar disposição final ambientalmente adequada aos resíduos e rejeitos oriundos dos serviços públicos de limpeza urbana e de manejo de resíduos sólidos.

$\S 1^{\text {o }}$ Para o cumprimento do disposto nos incisos I a IV do caput, o titular dos serviços públicos de limpeza urbana e de manejo de resíduos sólidos priorizará a organização e o funcionamento de cooperativas ou de outras formas de associação de catadores de materiais reutilizáveis e recicláveis formadas por pessoas físicas de baixa renda, bem como sua contratação.

$\S 2^{0}$ A contratação prevista no $\S 1^{\circ}$ é dispensável de licitação, nos termos do inciso

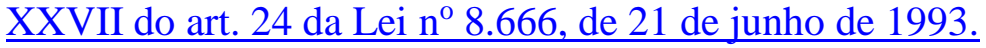

\section{CAPÍTULO IV}

\section{DOS RESÍDUOS PERIGOSOS}

Art. 37. A instalação e o funcionamento de empreendimento ou atividade que gere ou opere com resíduos perigosos somente podem ser autorizados ou licenciados pelas autoridades competentes se o responsável comprovar, no mínimo, capacidade técnica e econômica, além de condições para prover os cuidados necessários ao gerenciamento desses resíduos.

Art. 38. As pessoas jurídicas que operam com resíduos perigosos, em qualquer fase do seu gerenciamento, são obrigadas a se cadastrar no Cadastro Nacional de Operadores de Resíduos Perigosos.

$\S 1^{\mathrm{o}} \mathrm{O}$ cadastro previsto no caput será coordenado pelo órgão federal competente do Sisnama e implantado de forma conjunta pelas autoridades federais, estaduais e municipais.

$\S 2^{\mathrm{o}}$ Para o cadastramento, as pessoas jurídicas referidas no caput necessitam contar com responsável técnico pelo gerenciamento dos resíduos perigosos, de seu próprio quadro de funcionários ou contratado, devidamente habilitado, cujos dados serão mantidos atualizados no cadastro. 
$\S 3^{\mathrm{o}} \mathrm{O}$ cadastro a que se refere o caput é parte integrante do Cadastro Técnico Federal de Atividades Potencialmente Poluidoras ou Utilizadoras de Recursos Ambientais e do Sistema de Informações previsto no art. 12.

Art. 39. As pessoas jurídicas referidas no art. 38 são obrigadas a elaborar plano de gerenciamento de resíduos perigosos e submetê-lo ao órgão competente do Sisnama e, se couber, do SNVS, observado o conteúdo mínimo estabelecido no art. 21 e demais exigências previstas em regulamento ou em normas técnicas.

$\S 1^{\text {o }}$ O plano de gerenciamento de resíduos perigosos a que se refere o caput poderá estar inserido no plano de gerenciamento de resíduos a que se refere o art. 20.

$\S 2^{\circ}$ Cabe às pessoas jurídicas referidas no art. 38:

I - manter registro atualizado e facilmente acessível de todos os procedimentos relacionados à implementação e à operacionalização do plano previsto no caput;

II - informar anualmente ao órgão competente do Sisnama e, se couber, do SNVS, sobre a quantidade, a natureza e a destinação temporária ou final dos resíduos sob sua responsabilidade;

III - adotar medidas destinadas a reduzir o volume e a periculosidade dos resíduos sob sua responsabilidade, bem como a aperfeiçoar seu gerenciamento;

IV - informar imediatamente aos órgãos competentes sobre a ocorrência de acidentes ou outros sinistros relacionados aos resíduos perigosos.

$\S 3^{\text {o }}$ Sempre que solicitado pelos órgãos competentes do Sisnama e do SNVS, será assegurado acesso para inspeção das instalações e dos procedimentos relacionados à implementação e à operacionalização do plano de gerenciamento de resíduos perigosos.

$\S 4^{0}$ No caso de controle a cargo de órgão federal ou estadual do Sisnama e do SNVS, as informações sobre o conteúdo, a implementação e a operacionalização do plano previsto no caput serão repassadas ao poder público municipal, na forma do regulamento.

Art. 40. No licenciamento ambiental de empreendimentos ou atividades que operem com resíduos perigosos, o órgão licenciador do Sisnama pode exigir a contratação de seguro de responsabilidade civil por danos causados ao meio ambiente ou à saúde pública, observadas as regras sobre cobertura e os limites máximos de contratação fixados em regulamento.

Parágrafo único. O disposto no caput considerará o porte da empresa, conforme regulamento.

Art. 41. Sem prejuízo das iniciativas de outras esferas governamentais, o Governo Federal deve estruturar e manter instrumentos e atividades voltados para promover a descontaminação de áreas órfãs.

Parágrafo único. Se, após descontaminação de sítio órfão realizada com recursos do Governo Federal ou de outro ente da Federação, forem identificados os responsáveis pela contaminação, estes ressarcirão integralmente o valor empregado ao poder público. 


\section{CAPÍTULO V}

\section{DOS INSTRUMENTOS ECONÔMICOS}

Art. 42. O poder público poderá instituir medidas indutoras e linhas de financiamento para atender, prioritariamente, às iniciativas de:

I - prevenção e redução da geração de resíduos sólidos no processo produtivo;

II - desenvolvimento de produtos com menores impactos à saúde humana e à qualidade ambiental em seu ciclo de vida;

III - implantação de infraestrutura física e aquisição de equipamentos para cooperativas ou outras formas de associação de catadores de materiais reutilizáveis e recicláveis formadas por pessoas físicas de baixa renda;

IV - desenvolvimento de projetos de gestão dos resíduos sólidos de caráter intermunicipal ou, nos termos do inciso I do caput do art. 11, regional;

V - estruturação de sistemas de coleta seletiva e de logística reversa;

VI - descontaminação de áreas contaminadas, incluindo as áreas órfãs;

VII - desenvolvimento de pesquisas voltadas para tecnologias limpas aplicáveis aos resíduos sólidos;

VIII - desenvolvimento de sistemas de gestão ambiental e empresarial voltados para a melhoria dos processos produtivos e ao reaproveitamento dos resíduos.

Art. 43. No fomento ou na concessão de incentivos creditícios destinados a atender diretrizes desta Lei, as instituições oficiais de crédito podem estabelecer critérios diferenciados de acesso dos beneficiários aos créditos do Sistema Financeiro Nacional para investimentos produtivos.

Art. 44. A União, os Estados, o Distrito Federal e os Municípios, no âmbito de suas competências, poderão instituir normas com o objetivo de conceder incentivos fiscais, financeiros ou creditícios, respeitadas as limitações da Lei Complementar $n^{\circ} 101$, de 4 de maio de 2000 (Lei de Responsabilidade Fiscal), a:

I - indústrias e entidades dedicadas à reutilização, ao tratamento e à reciclagem de resíduos sólidos produzidos no território nacional;

II - projetos relacionados à responsabilidade pelo ciclo de vida dos produtos, prioritariamente em parceria com cooperativas ou outras formas de associação de catadores de materiais reutilizáveis e recicláveis formadas por pessoas físicas de baixa renda;

III - empresas dedicadas à limpeza urbana e a atividades a ela relacionadas.

Art. 45. Os consórcios públicos constituídos, nos termos da Lei n ${ }^{0} 11.107$, de 2005, com o objetivo de viabilizar a descentralização e a prestação de serviços públicos que envolvam resíduos sólidos, têm prioridade na obtenção dos incentivos instituídos pelo Governo Federal. 
Art. 46. O atendimento ao disposto neste Capítulo será efetivado em consonância com a Lei Complementar $n^{\circ} 101$, de 2000 (Lei de Responsabilidade Fiscal), bem como com as diretrizes e objetivos do respectivo plano plurianual, as metas e as prioridades fixadas pelas leis de diretrizes orçamentárias e no limite das disponibilidades propiciadas pelas leis orçamentárias anuais.

\section{CAPÍTULO VI}

\section{DAS PROIBIÇÕES}

Art. 47. São proibidas as seguintes formas de destinação ou disposição final de resíduos sólidos ou rejeitos:

I - lançamento em praias, no mar ou em quaisquer corpos hídricos;

II - lançamento in natura a céu aberto, excetuados os resíduos de mineração;

III - queima a céu aberto ou em recipientes, instalações e equipamentos não licenciados para essa finalidade;

IV - outras formas vedadas pelo poder público.

§ 1ํ Quando decretada emergência sanitária, a queima de resíduos a céu aberto pode ser realizada, desde que autorizada e acompanhada pelos órgãos competentes do Sisnama, do SNVS e, quando couber, do Suasa.

$\S 2^{\circ}$ Assegurada a devida impermeabilização, as bacias de decantação de resíduos ou rejeitos industriais ou de mineração, devidamente licenciadas pelo órgão competente do Sisnama, não são consideradas corpos hídricos para efeitos do disposto no inciso I do caput.

Art. 48. São proibidas, nas áreas de disposição final de resíduos ou rejeitos, as seguintes atividades:

I - utilização dos rejeitos dispostos como alimentação;

II - catação, observado o disposto no inciso V do art. 17;

III - criação de animais domésticos;

IV - fixação de habitações temporárias ou permanentes;

V - outras atividades vedadas pelo poder público.

Art. 49. É proibida a importação de resíduos sólidos perigosos e rejeitos, bem como de resíduos sólidos cujas características causem dano ao meio ambiente, à saúde pública e animal e à sanidade vegetal, ainda que para tratamento, reforma, reúso, reutilização ou recuperação.

\section{TÍTULO IV}

\section{DISPOSIÇÕES TRANSITÓRIAS E FINAIS}


Art. 50. A inexistência do regulamento previsto no $\S 3^{0}$ do art. 21 não obsta a atuação, nos termos desta Lei, das cooperativas ou outras formas de associação de catadores de materiais reutilizáveis e recicláveis.

Art. 51. Sem prejuízo da obrigação de, independentemente da existência de culpa, reparar os danos causados, a ação ou omissão das pessoas físicas ou jurídicas que importe inobservância aos preceitos desta Lei ou de seu regulamento sujeita os infratores às sanções previstas em lei, em especial às fixadas na Lei $\mathrm{n}^{0} 9.605$, de 12 de fevereiro de 1998, que "dispõe sobre as sanções penais e administrativas derivadas de condutas e atividades lesivas ao meio ambiente, e dá outras providências”, e em seu regulamento.

Art. 52. A observância do disposto no caput do art. 23 e no $§ 2^{\circ}$ do art. 39 desta Lei é considerada obrigação de relevante interesse ambiental para efeitos do art. 68 da Lei $\mathrm{n}^{\circ}$ 9.605, de 1998, sem prejuízo da aplicação de outras sanções cabíveis nas esferas penal e administrativa.

Art. 53. O $\S 1^{\mathrm{o}}$ do art. 56 da Lei ${ }^{\circ}$ 9.605, de 12 de fevereiro de 1998 , passa a vigorar com a seguinte redação:

"Art. 56.

$\S 1^{\mathrm{o}}$ Nas mesmas penas incorre quem:

I - abandona os produtos ou substâncias referidos no caput ou os utiliza em desacordo com as normas ambientais ou de segurança;

II - manipula, acondiciona, armazena, coleta, transporta, reutiliza, recicla ou dá destinação final a resíduos perigosos de forma diversa da estabelecida em lei ou regulamento.

$"(\mathrm{NR})$

Art. 54. A disposição final ambientalmente adequada dos rejeitos, observado o disposto no $\S 1^{\circ}$ do art. 9oㅡㄹ deverá ser implantada em até 4 (quatro) anos após a data de publicação desta Lei.

Art. 55. O disposto nos arts. 16 e $\underline{18}$ entra em vigor 2 (dois) anos após a data de publicação desta Lei.

Art. 56. A logística reversa relativa aos produtos de que tratam os incisos V e VI do caput do art. 33 será implementada progressivamente segundo cronograma estabelecido em regulamento.

Art. 57. Esta Lei entra em vigor na data de sua publicação.

Brasília, 2 de agosto de 2010; 189º da Independência e $122^{\circ}$ da República.

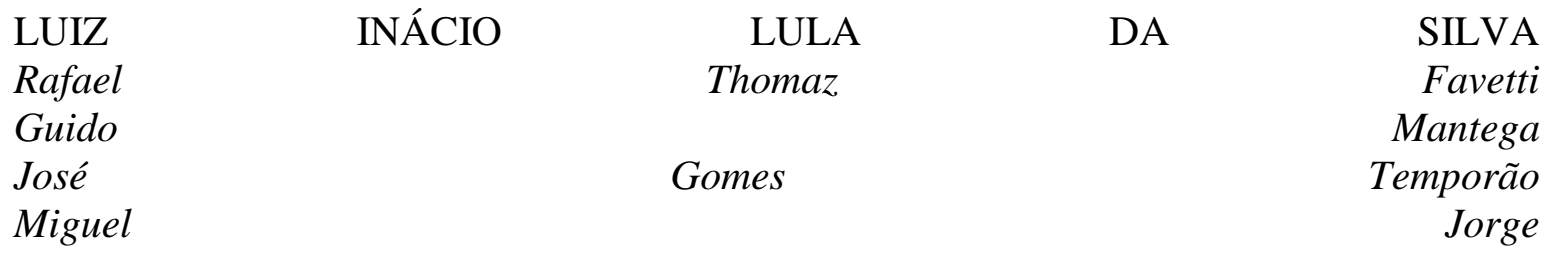




$\begin{array}{lccr}\text { Izabella } & \text { Mônica } & \text { Vieira } & \text { Teixeira } \\ \text { João } & \text { Reis } & \text { Santana } & \text { Filho } \\ \text { Marcio } & \text { Fortes } & \text { de } & \text { Almeida }\end{array}$

Alexandre Rocha Santos Padilha

Este texto não substitui o publicado no DOU de 3.8.2010 


\section{Presidência da República \\ Casa Civil \\ Subchefia para Assuntos Jurídicos}

DECRETO No 7.404, DE 23 DE DEZEMBRO DE 2010.

Regulamenta a Lei $\mathrm{n}^{\mathrm{o}} 12.305$, de 2 de agosto de 2010, que institui a Política Nacional de

Resíduos Sólidos, cria o Comitê Interministerial da Política Nacional de Resíduos Sólidos e o Comitê Orientador para a Implantação dos Sistemas de Logística Reversa, e dá outras providências.

O PRESIDENTE DA REPÚBLICA, no uso das atribuições que lhe confere o art. 84, incisos IV e VI, alínea "a", da Constituição, e tendo em vista o disposto na Lei no 12.305, de 2 de agosto de 2010,

\section{DECRETA:}

\section{TÍTULO I}

\section{DAS DISPOSIÇÕES PRELIMINARES}

Art. $1^{\mathrm{o}}$ Este Decreto estabelece normas para execução da Política Nacional de Resíduos Sólidos, de que trata a Lei $\mathrm{n}^{\mathrm{0}} 12.305$, de 2 de agosto de 2010.

Art. 2ํ A Política Nacional de Resíduos Sólidos integra a Política Nacional do Meio Ambiente e articula-se com as diretrizes nacionais para o saneamento básico e com a Política Federal de Saneamento Básico, nos termos da Lei $\mathrm{n}^{\circ} 11.445$, de 5 de janeiro de 2007, com a Lei ${ }^{0} 11.107$, de 6 de abril de 2005, e com a Política Nacional de Educação Ambiental, regulada pela Lei ${ }^{\circ}$ 9.795, de 27 de abril de 1999.

\section{TÍTULO II}

\section{DO COMITÊ INTERMINISTERIAL DA POLÍTICA NACIONAL DE RESÍDUOS SÓLIDOS}

Art. 3ํ Fica instituído o Comitê Interministerial da Política Nacional de Resíduos Sólidos, com a finalidade de apoiar a estruturação e implementação da Política Nacional de Resíduos Sólidos, por meio da articulação dos órgãos e entidades governamentais, de modo a possibilitar o cumprimento das determinações e das metas previstas na Lei $\mathrm{n}^{\circ}$ 12.305 , de 2010, e neste Decreto, com um representante, titular e suplente, de cada órgão a seguir indicado:

I - Ministério do Meio Ambiente, que o coordenará;

II - Casa Civil da Presidência da República; 
III - Ministério das Cidades;

IV - Ministério do Desenvolvimento Social e Combate à Fome;

V - Ministério da Saúde;

VI - Ministério de Minas e Energia;

VII - Ministério da Fazenda;

VIII - Ministério do Planejamento, Orçamento e Gestão;

IX - Ministério do Desenvolvimento, Indústria e Comércio Exterior;

X - Ministério da Agricultura, Pecuária e Abastecimento;

XI - Ministério da Ciência e Tecnologia; e

XII - Secretaria de Relações Institucionais da Presidência da República.

$\S 1^{0}$ Os membros do Comitê Interministerial serão indicados pelos titulares dos órgãos nele representados e designados pelo Ministro de Estado do Meio Ambiente.

$\S 2^{\circ}$ O Comitê Interministerial poderá convidar representantes de outros órgãos e entidades, públicas ou privadas, para participar de suas reuniões.

§ 3ㅇ O Comitê Interministerial poderá criar grupos técnicos compostos por representantes dos órgãos mencionados no caput, de outros órgãos públicos, bem como de entidades públicas ou privadas.

$\S 4^{\circ}$ O Comitê Interministerial indicará o coordenador dos grupos técnicos referidos no $\S 3$ ㅇ․

$\S 5^{\circ}$ Caberá ao Ministério do Meio Ambiente prestar apoio técnico-administrativo às atividades do Comitê Interministerial.

§ 6º A participação no Comitê Interministerial será considerada serviço público relevante, não remunerada.

Art. $4^{\mathrm{o}}$ Compete ao Comitê Interministerial:

I - instituir os procedimentos para elaboração do Plano Nacional de Resíduos Sólidos, observado o disposto no art. 15 da Lei $\mathrm{n}^{\circ} 12.305$, de 2010;

II - elaborar e avaliar a implementação do Plano Nacional de Resíduos Sólidos, observado o disposto no art. 15 da Lei $\mathrm{n}^{\mathrm{o}} 12.305$, de 2010;

III - definir as informações complementares ao Plano de Gerenciamento de Resíduos Sólidos Perigosos, conforme o art. 39 da Lei n ${ }^{\circ} 12.305$, de 2010; 
IV - promover estudos e propor medidas visando a desoneração tributária de produtos recicláveis e reutilizáveis e a simplificação dos procedimentos para o cumprimento de obrigações acessórias relativas à movimentação de produtos e embalagens fabricados com estes materiais;

V - promover estudos visando a criação, modificação e extinção de condições para a utilização de linhas de financiamento ou creditícias de instituições financeiras federais;

VI - formular estratégia para a promoção e difusão de tecnologias limpas para a gestão e o gerenciamento de resíduos sólidos;

VII - incentivar a pesquisa e o desenvolvimento nas atividades de reciclagem, reaproveitamento e tratamento dos resíduos sólidos;

VIII - propor medidas para a implementação dos instrumentos e efetivação dos objetivos da Política Nacional de Resíduos Sólidos;

IX - definir e avaliar a implantação de mecanismos específicos voltados para promover a descontaminação de áreas órfãs, nos termos do art. 41 da Lei $\mathrm{n}^{\circ} 12.305$, de 2010

X - implantar ações destinadas a apoiar a elaboração, implementação, execução e revisão dos planos de resíduos sólidos referidos no art. 14 da Lei n ${ }^{\circ} 12.305$, de 2010; e

XI - contribuir, por meio de estudos específicos, com o estabelecimento de mecanismos de cobrança dos serviços de limpeza urbana e manejo de resíduos sólidos urbanos pelos seus respectivos titulares.

\section{TÍTULO III}

\section{DAS RESPONSABILIDADES DOS GERADORES DE RESÍDUOS SÓLIDOS E DO PODER PÚBLICO}

\section{CAPÍTULO I}

\section{DAS DISPOSIÇÕES GERAIS}

Art. 5 Os fabricantes, importadores, distribuidores, comerciantes, consumidores e titulares dos serviços públicos de limpeza urbana e de manejo de resíduos sólidos são responsáveis pelo ciclo de vida dos produtos.

Parágrafo único. A responsabilidade compartilhada será implementada de forma individualizada e encadeada.

Art. $6^{0}$ Os consumidores são obrigados, sempre que estabelecido sistema de coleta seletiva pelo plano municipal de gestão integrada de resíduos sólidos ou quando instituídos sistemas de logística reversa na forma do art. 15, a acondicionar adequadamente e de forma diferenciada os resíduos sólidos gerados e a disponibilizar adequadamente os resíduos sólidos reutilizáveis e recicláveis para coleta ou devolução. 
Parágrafo único A obrigação referida no caput não isenta os consumidores de observar as regras de acondicionamento, segregação e destinação final dos resíduos previstas na legislação do titular do serviço público de limpeza urbana e manejo de resíduos sólidos.

Art. 7ํㅡ O Poder Público, o setor empresarial e a coletividade são responsáveis pela efetividade das ações voltadas para assegurar a observância da Política Nacional de Resíduos Sólidos e das diretrizes e determinações estabelecidas na Lei $\mathrm{n}^{\circ} 12.305$, de 2010 , e neste Decreto.

Art. $8^{\circ} \mathrm{O}$ disposto no art. 32 da Lei $\mathrm{n}^{\circ} 12.305$, de 2010 , não se aplica às embalagens de produtos destinados à exportação, devendo o fabricante atender às exigências do país importador.

\section{CAPÍTULO II}

\section{DA COLETA SELETIVA}

Art. 9ํ A coleta seletiva dar-se-á mediante a segregação prévia dos resíduos sólidos, conforme sua constituição ou composição.

$\S 1^{\mathrm{o}}$ A implantação do sistema de coleta seletiva é instrumento essencial para se atingir a meta de disposição final ambientalmente adequada dos rejeitos, conforme disposto no art. 54 da Lei n $^{\circ} 12.305$, de 2010.

$\S 2^{\circ} \mathrm{O}$ sistema de coleta seletiva será implantado pelo titular do serviço público de limpeza urbana e manejo de resíduos sólidos e deverá estabelecer, no mínimo, a separação de resíduos secos e úmidos e, progressivamente, ser estendido à separação dos resíduos secos em suas parcelas específicas, segundo metas estabelecidas nos respectivos planos.

$\S 3^{\circ}$ Para o atendimento ao disposto neste artigo, os geradores de resíduos sólidos deverão segregá-los e disponibilizá-los adequadamente, na forma estabelecida pelo titular do serviço público de limpeza urbana e manejo de resíduos sólidos.

Art. 10. Os titulares do serviço público de limpeza urbana e manejo de resíduos sólidos, em sua área de abrangência, definirão os procedimentos para o acondicionamento adequado e disponibilização dos resíduos sólidos objeto da coleta seletiva.

Art. 11. O sistema de coleta seletiva de resíduos sólidos priorizará a participação de cooperativas ou de outras formas de associação de catadores de materiais reutilizáveis e recicláveis constituídas por pessoas físicas de baixa renda.

Art. 12. A coleta seletiva poderá ser implementada sem prejuízo da implantação de sistemas de logística reversa.

\section{CAPÍTULO III}

DA LOGÍSTICA REVERSA 


\section{Das Disposições Gerais}

Art. 13. A logística reversa é o instrumento de desenvolvimento econômico e social caracterizado pelo conjunto de ações, procedimentos e meios destinados a viabilizar a coleta e a restituição dos resíduos sólidos ao setor empresarial, para reaproveitamento, em seu ciclo ou em outros ciclos produtivos, ou outra destinação final ambientalmente adequada.

Art. 14. O sistema de logística reversa de agrotóxicos, seus resíduos e embalagens, seguirá o disposto na Lei $\mathrm{n}^{\mathrm{o}} 7.802$, de 11 de julho de 1989, e no Decreto $\mathrm{n}^{\circ} 4.074$, de 4 de janeiro de 2002.

\section{Seção II}

\section{Dos Instrumentos e da Forma de Implantação da Logística Reversa}

Art. 15. Os sistemas de logística reversa serão implementados e operacionalizados por meio dos seguintes instrumentos:

I - acordos setoriais;

II - regulamentos expedidos pelo Poder Público; ou

III - termos de compromisso.

$\S 1^{0}$ Os acordos setoriais firmados com menor abrangência geográfica podem ampliar, mas não abrandar, as medidas de proteção ambiental constantes dos acordos setoriais e termos de compromisso firmados com maior abrangência geográfica.

$\S 2^{\circ}$ Com o objetivo de verificar a necessidade de sua revisão, os acordos setoriais, os regulamentos e os termos de compromisso que disciplinam a logística reversa no âmbito federal deverão ser avaliados pelo Comitê Orientador referido na Seção III em até cinco anos contados da sua entrada em vigor.

Art. 16. Os sistemas de logística reversa dos produtos e embalagens previstos no art.

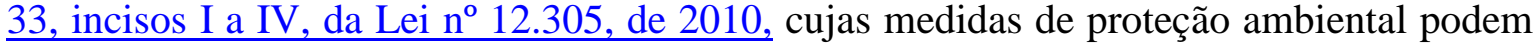
ser ampliadas mas não abrandadas, deverão observar as exigências específicas previstas em:

I - lei ou regulamento;

II - normas estabelecidas pelos órgãos do Sistema Nacional do Meio Ambiente SISNAMA, do Sistema Nacional de Vigilância Sanitária - SNVS, do Sistema Único de Atenção à Sanidade Agropecuária - SUASA e em outras normas aplicáveis; ou

III - acordos setoriais e termos de compromisso.

Art. 17. Os sistemas de logística reversa serão estendidos, por meio da utilização dos instrumentos previstos no art. 15, a produtos comercializados em embalagens plásticas, 
metálicas ou de vidro, e aos demais produtos e embalagens, considerando prioritariamente o grau e a extensão do impacto à saúde pública e ao meio ambiente dos resíduos gerados.

Parágrafo único. A definição dos produtos e embalagens a que se refere o caput deverá considerar a viabilidade técnica e econômica da logística reversa, a ser aferida pelo Comitê Orientador.

Art. 18. Os fabricantes, importadores, distribuidores e comerciantes dos produtos referidos nos incisos II, III, V e VI do art. 33 da Lei $n^{\circ} 12.305$, de 2010, bem como dos produtos e embalagens referidos nos incisos I e IV e no $\S 1^{\circ}$ do art. 33 daquela Lei, deverão estruturar e implementar sistemas de logística reversa, mediante o retorno dos produtos e embalagens após o uso pelo consumidor.

$\S 1^{\underline{o}} \mathrm{Na}$ implementação e operacionalização do sistema de logística reversa poderão ser adotados procedimentos de compra de produtos ou embalagens usadas e instituídos postos de entrega de resíduos reutilizáveis e recicláveis, devendo ser priorizada, especialmente no caso de embalagens pós-consumo, a participação de cooperativas ou outras formas de associações de catadores de materiais recicláveis ou reutilizáveis.

$\S 2^{\underline{o}}$ Para o cumprimento do disposto no caput, os fabricantes, importadores, distribuidores e comerciantes ficam responsáveis pela realização da logística reversa no limite da proporção dos produtos que colocarem no mercado interno, conforme metas progressivas, intermediárias e finais, estabelecidas no instrumento que determinar a implementação da logística reversa.

\section{Subseção I}

\section{Dos Acordos Setoriais}

Art. 19. Os acordos setoriais são atos de natureza contratual, firmados entre o Poder Público e os fabricantes, importadores, distribuidores ou comerciantes, visando a implantação da responsabilidade compartilhada pelo ciclo de vida do produto.

Art. 20. O procedimento para implantação da logística reversa por meio de acordo setorial poderá ser iniciado pelo Poder Público ou pelos fabricantes, importadores, distribuidores ou comerciantes dos produtos e embalagens referidos no art. 18.

$\S 1^{\mathrm{o}}$ Os acordos setoriais iniciados pelo Poder Público serão precedidos de editais de chamamento, conforme procedimento estabelecido nesta Subseção.

$\S 2^{\mathrm{o}}$ Os acordos setoriais iniciados pelos fabricantes, importadores, distribuidores ou comerciantes serão precedidos da apresentação de proposta formal pelos interessados ao Ministério de Meio Ambiente, contendo os requisitos referidos no art. 23.

$\S 3^{0}$ Poderão participar da elaboração dos acordos setoriais representantes do Poder Público, dos fabricantes, importadores, comerciantes e distribuidores dos produtos e embalagens referidos no art. 33 da Lei $\mathrm{n}^{\circ} 12.305$, de 2010, das cooperativas ou outras formas de associações de catadores de materiais recicláveis ou reutilizáveis, das indústrias e entidades dedicadas à reutilização, ao tratamento e à reciclagem de resíduos sólidos, bem como das entidades de representação dos consumidores, entre outros. 
Art. 21. No caso dos procedimentos de iniciativa da União, a implantação da logística reversa por meio de acordo setorial terá início com a publicação de editais de chamamento pelo Ministério do Meio Ambiente, que poderão indicar:

I - os produtos e embalagens que serão objeto da logística reversa, bem como as etapas do ciclo de vida dos produtos e embalagens que estarão inseridas na referida logística;

II - o chamamento dos interessados, conforme as especificidades dos produtos e embalagens referidos no inciso I;

III - o prazo para que o setor empresarial apresente proposta de acordo setorial, observados os requisitos mínimos estabelecidos neste Decreto e no edital;

IV - as diretrizes metodológicas para avaliação dos impactos sociais e econômicos da implantação da logística reversa;

V - a abrangência territorial do acordo setorial; e

VI - outros requisitos que devam ser atendidos pela proposta de acordo setorial, conforme as especificidades dos produtos ou embalagens objeto da logística reversa.

$\S 1^{o}$ A publicação do edital de chamamento será precedida da aprovação, pelo Comitê Orientador, da avaliação da viabilidade técnica e econômica da implantação da logística reversa, promovida pelo grupo técnico previsto no $\S 3^{\circ}$ do art. 33 .

$\S 2^{\circ}$ As diretrizes metodológicas para avaliação dos impactos sociais e econômicos da implantação da logística reversa referidas no inciso IV do caput serão estabelecidas pelo Comitê Orientador.

Art. 22. No caso dos procedimentos de iniciativa dos fabricantes, importadores, distribuidores ou comerciantes, as propostas de acordo setorial serão avaliadas pelo Ministério do Meio Ambiente, consoante os critérios previstos no art. 28, que as enviará ao Comitê Orientador para as providências previstas no art. 29.

Art. 23. Os acordos setoriais visando a implementação da logística reversa deverão conter, no mínimo, os seguintes requisitos:

I - indicação dos produtos e embalagens objeto do acordo setorial;

II - descrição das etapas do ciclo de vida em que o sistema de logística reversa se insere, observado o disposto no inciso IV do art. $3^{\circ}$ da Lei ${ }^{\circ} 12.305$, de 2010;

III - descrição da forma de operacionalização da logística reversa;

IV - possibilidade de contratação de entidades, cooperativas ou outras formas de associação de catadores de materiais recicláveis ou reutilizáveis, para execução das ações propostas no sistema a ser implantado; 
V-participação de órgãos públicos nas ações propostas, quando estes se encarregarem de alguma etapa da logística a ser implantada;

VI - definição das formas de participação do consumidor;

VII - mecanismos para a divulgação de informações relativas aos métodos existentes para evitar, reciclar e eliminar os resíduos sólidos associados a seus respectivos produtos e embalagens;

VIII - metas a serem alcançadas no âmbito do sistema de logística reversa a ser implantado;

IX - cronograma para a implantação da logística reversa, contendo a previsão de evolução até o cumprimento da meta final estabelecida;

$\mathrm{X}$ - informações sobre a possibilidade ou a viabilidade de aproveitamento dos resíduos gerados, alertando para os riscos decorrentes do seu manuseio;

XI - identificação dos resíduos perigosos presentes nas várias ações propostas e os cuidados e procedimentos previstos para minimizar ou eliminar seus riscos e impactos à saúde humana e ao meio ambiente; reversa;

XII - avaliação dos impactos sociais e econômicos da implantação da logística

XIII - descrição do conjunto de atribuições individualizadas e encadeadas dos participantes do sistema de logística reversa no processo de recolhimento, armazenamento, transporte dos resíduos e embalagens vazias, com vistas à reutilização, reciclagem ou disposição final ambientalmente adequada, contendo o fluxo reverso de resíduos, a discriminação das várias etapas da logística reversa e a destinação dos resíduos gerados, das embalagens usadas ou pós-consumo e, quando for o caso, das sobras do produto, devendo incluir:

a) recomendações técnicas a serem observadas em cada etapa da logística, inclusive pelos consumidores e recicladores;

b) formas de coleta ou de entrega adotadas, identificando os responsáveis e respectivas responsabilidades;

c) ações necessárias e critérios para a implantação, operação e atribuição de responsabilidades pelos pontos de coleta;

d) operações de transporte entre os empreendimentos ou atividades participantes, identificando as responsabilidades; e

e) procedimentos e responsáveis pelas ações de reutilização, de reciclagem e de tratamento, inclusive triagem, dos resíduos, bem como pela disposição final ambientalmente adequada dos rejeitos; e 
XIV - cláusulas prevendo as penalidades aplicáveis no caso de descumprimento das obrigações previstas no acordo.

Parágrafo único. As metas referidas no inciso VIII do caput poderão ser fixadas com base em critérios quantitativos, qualitativos ou regionais.

Art. 24. Durante as discussões para a elaboração do acordo setorial, o grupo técnico a que se refere o $\S 3^{0}$ do art. 33 poderá promover iniciativas com vistas a estimular a adesão às negociações do acordo, bem como realizar reuniões com os integrantes da negociação, com vistas a que a proposta de acordo setorial obtenha êxito.

Art. 25. Deverão acompanhar a proposta de acordo setorial os seguintes documentos:

I - atos constitutivos das entidades participantes e relação dos associados de cada entidade, se for o caso;

II - documentos comprobatórios da qualificação dos representantes e signatários da proposta, bem como cópia dos respectivos mandatos; e

III - cópia de estudos, dados e demais informações que embasarem a proposta.

Art. 26. As propostas de acordo setorial serão objeto de consulta pública, na forma definida pelo Comitê Orientador.

Art. 27. O Ministério do Meio Ambiente deverá, por ocasião da realização da consulta pública:

I - receber e analisar as contribuições e documentos apresentados pelos órgãos e entidades públicas e privadas; e

II - sistematizar as contribuições recebidas, assegurando-lhes a máxima publicidade.

Art. 28. O Ministério do Meio Ambiente fará a avaliação das propostas de acordo setorial apresentadas consoante os seguintes critérios mínimos:

I - adequação da proposta à legislação e às normas aplicáveis;

II - atendimento ao edital de chamamento, no caso dos processos iniciados pelo Poder Público, e apresentação dos documentos que devem acompanhar a proposta, em qualquer caso;

III - contribuição da proposta e das metas apresentadas para a melhoria da gestão integrada e do gerenciamento ambientalmente adequado dos resíduos sólidos e para a redução dos impactos à saúde humana e ao meio ambiente;

IV - observância do disposto no art. $9^{\circ}$ da Lei ${ }^{\circ} 12.305$, de 2010 , quanto à ordem de prioridade da aplicação da gestão e gerenciamento de resíduos sólidos propostos; 
V - representatividade das entidades signatárias em relação à participação de seus membros no mercado dos produtos e embalagens envolvidos; e

VI - contribuição das ações propostas para a inclusão social e geração de emprego e renda dos integrantes de cooperativas e associações de catadores de materiais reutilizáveis e recicláveis constituídas por pessoas físicas de baixa renda.

Art. 29. Concluída a avaliação a que se refere o art. 28, o Ministério do Meio Ambiente a enviará ao Comitê Orientador, que poderá:

I - aceitar a proposta, hipótese em que convidará os representantes do setor empresarial para assinatura do acordo setorial;

II - solicitar aos representantes do setor empresarial a complementação da proposta de estabelecimento de acordo setorial; ou

III - determinar o arquivamento do processo, quando não houver consenso na negociação do acordo.

Parágrafo único. O acordo setorial contendo a logística reversa pactuada será subscrito pelos representantes do setor empresarial e pelo Presidente do Comitê Orientador, devendo ser publicado no Diário Oficial da União.

\section{Subseção II}

\section{Do Regulamento}

Art. 30. Sem prejuízo do disposto na Subseção I, a logística reversa poderá ser implantada diretamente por regulamento, veiculado por decreto editado pelo Poder Executivo.

Parágrafo único. Na hipótese prevista no caput, antes da edição do regulamento, o Comitê Orientador deverá avaliar a viabilidade técnica e econômica da logística reversa.

Art. 31. Os sistemas de logística reversa estabelecidos diretamente por decreto deverão ser precedidos de consulta pública, cujo procedimento será estabelecido pelo Comitê Orientador.

\section{Subseção III}

\section{Dos Termos de Compromisso}

Art. 32. O Poder Público poderá celebrar termos de compromisso com os fabricantes, importadores, distribuidores ou comerciantes referidos no art. 18, visando o estabelecimento de sistema de logística reversa:

I - nas hipóteses em que não houver, em uma mesma área de abrangência, acordo setorial ou regulamento específico, consoante estabelecido neste Decreto; ou 
II - para a fixação de compromissos e metas mais exigentes que o previsto em acordo setorial ou regulamento.

Parágrafo único. Os termos de compromisso terão eficácia a partir de sua homologação pelo órgão ambiental competente do SISNAMA, conforme sua abrangência territorial.

\section{Seção III}

\section{Do Comitê Orientador para Implementação de Sistemas de Logística Reversa}

Art. 33. Fica instituído o Comitê Orientador para Implantação de Sistemas de Logística Reversa - Comitê Orientador, com a seguinte composição:

I - Ministro de Estado do Meio Ambiente;

II - Ministro de Estado da Saúde;

III - Ministro de Estado do Desenvolvimento, Indústria e Comércio Exterior;

IV - Ministro de Estado da Agricultura, Pecuária e Abastecimento; e

V - Ministro de Estado da Fazenda.

$\S 1^{\text {o }}$ O Comitê Orientador será presidido pelo Ministro de Estado do Meio Ambiente.

$\S 2^{\circ}$ O Ministério do Meio Ambiente exercerá a função de secretaria-executiva do Comitê Orientador e expedirá os atos decorrentes das decisões do colegiado.

§ 3o O Comitê Orientador será assessorado por grupo técnico, composto por representantes do Ministério do Meio Ambiente, do Ministério da Saúde, do Ministério do Desenvolvimento, Indústria e Comércio Exterior, do Ministério da Fazenda e do Ministério de Agricultura, Pecuária e Abastecimento.

$\S 4^{0}$ Nas hipóteses em que forem abordados temas referentes às suas respectivas competências ou áreas de atuação, o Comitê Orientador poderá convidar a compor o grupo técnico referido no $\S 3^{\circ}$ representantes:

I - de outros Ministérios, de órgãos e entidades da administração pública federal;

II - dos Estados, do Distrito Federal e dos Municípios; e

III - de entidades representativas de setores da sociedade civil diretamente impactados pela logística reversa.

$\S 6^{\mathrm{o}}$ As decisões do Comitê Orientador serão tomadas por maioria simples de votos, presente a maioria absoluta dos membros. 
$\S 7^{0}$ Os membros referidos no caput elaborarão o regimento interno do Comitê Orientador, que deverá conter, no mínimo:

I - o procedimento para divulgação da pauta das reuniões;

II - os critérios para participação dos órgãos e entidades no grupo técnico de que trata o $§ 4$;

III - as regras para o funcionamento do grupo técnico de assessoramento e do colegiado; e

IV - os critérios de decisão no caso de empate nas deliberações colegiadas.

Art. 34. Compete ao Comitê Orientador:

I - estabelecer a orientação estratégica da implementação de sistemas de logística reversa instituídos nos termos da Lei $\mathrm{n}^{\circ} 12.305$, de 2010, e deste Decreto;

II - definir as prioridades e aprovar o cronograma para o lançamento de editais de chamamento de propostas de acordo setorial para a implantação de sistemas de logística reversa de iniciativa da União;

III - fixar cronograma para a implantação dos sistemas de logística reversa;

IV - aprovar os estudos de viabilidade técnica e econômica;

V-definir as diretrizes metodológicas para avaliação dos impactos sociais e econômicos dos sistemas de logística reversa;

VI - avaliar a necessidade da revisão dos acordos setoriais, dos regulamentos e dos termos de compromisso que disciplinam a logística reversa no âmbito federal;

VII - definir as embalagens que ficam dispensadas, por razões de ordem técnica ou econômica, da obrigatoriedade de fabricação com materiais que propiciem a reutilização e reciclagem;

VIII - definir a forma de realização da consulta pública relativa a proposta de implementação de sistemas de logística reversa;

IX - promover estudos e propor medidas de desoneração tributária das cadeias produtivas sujeitas à logística reversa e a simplificação dos procedimentos para o cumprimento de obrigações acessórias relativas à movimentação de produtos e embalagens sujeitos à logística reversa; e

$\mathrm{X}$ - propor medidas visando incluir nos sistemas de logística reversa os produtos e embalagens adquiridos diretamente de empresas não estabelecidas no País, inclusive por meio de comércio eletrônico.

\section{TÍTULO IV}




\section{DAS DIRETRIZES APLICÁVEIS À GESTÃO E GERENCIAMENTO DOS RESÍDUOS SÓLIDOS}

Art. 35. Na gestão e gerenciamento de resíduos sólidos, deverá ser observada a seguinte ordem de prioridade: não geração, redução, reutilização, reciclagem, tratamento dos resíduos sólidos e disposição final ambientalmente adequada dos rejeitos.

Art. 36. A utilização de resíduos sólidos nos processos de recuperação energética, incluindo o co-processamento, obedecerá às normas estabelecidas pelos órgãos competentes.

Art. 37. A recuperação energética dos resíduos sólidos urbanos referida no $\S 1^{\circ}$ do art. $9^{\circ}$ da Lei $\mathrm{n}^{\circ} 12.305$, de 2010, assim qualificados consoante o art. 13, inciso I, alínea "c", daquela Lei, deverá ser disciplinada, de forma específica, em ato conjunto dos Ministérios do Meio Ambiente, de Minas e Energia e das Cidades.

Parágrafo único. O disposto neste artigo não se aplica ao aproveitamento energético dos gases gerados na biodigestão e na decomposição da matéria orgânica dos resíduos sólidos urbanos em aterros sanitários.

Art. 38. Os geradores de resíduos sólidos deverão adotar medidas que promovam a redução da geração dos resíduos, principalmente os resíduos perigosos, na forma prevista nos respectivos planos de resíduos sólidos e nas demais normas aplicáveis.

Art. 39. O gerenciamento dos resíduos sólidos presumidamente veiculadores de agentes etiológicos de doenças transmissíveis ou de pragas, dos resíduos de serviços de transporte gerados em portos, aeroportos e passagens de fronteira, bem como de material apreendido proveniente do exterior, observará o estabelecido nas normas do SISNAMA, do SNVS e do SUASA, relativamente à suas respectivas áreas de atuação.

\section{TÍTULO V}

\section{DA PARTICIPAÇÃO DOS CATADORES DE MATERIAIS RECICLÁVEIS E REUTILIZÁVEIS}

Art. 40. O sistema de coleta seletiva de resíduos sólidos e a logística reversa priorizarão a participação de cooperativas ou de outras formas de associação de catadores de materiais reutilizáveis e recicláveis constituídas por pessoas físicas de baixa renda.

Art. 41. Os planos municipais de gestão integrada de resíduos sólidos definirão programas e ações para a participação dos grupos interessados, em especial das cooperativas ou outras formas de associação de catadores de materiais reutilizáveis e recicláveis formadas por pessoas físicas de baixa renda.

Art. 42. As ações desenvolvidas pelas cooperativas ou outras formas de associação de catadores de materiais reutilizáveis e recicláveis no âmbito do gerenciamento de resíduos sólidos das atividades relacionadas no art. 20 da Lei ${ }^{\circ} 12.305$, de 2010, deverão estar descritas, quando couber, nos respectivos planos de gerenciamento de resíduos sólidos. 
Art. 43. A União deverá criar, por meio de regulamento específico, programa com a finalidade de melhorar as condições de trabalho e as oportunidades de inclusão social e econômica dos catadores de materiais reutilizáveis e recicláveis.

Art. 44. As políticas públicas voltadas aos catadores de materiais reutilizáveis e recicláveis deverão observar:

I - a possibilidade de dispensa de licitação, nos termos do inciso XXVII do art. 24 da Lei $\mathrm{n}^{0} 8.666$, de 21 de junho de 1993 , para a contratação de cooperativas ou associações de catadores de materiais reutilizáveis e recicláveis;

II - o estímulo à capacitação, à incubação e ao fortalecimento institucional de cooperativas, bem como à pesquisa voltada para sua integração nas ações que envolvam a responsabilidade compartilhada pelo ciclo de vida dos produtos; e

III - a melhoria das condições de trabalho dos catadores.

Parágrafo único. Para o atendimento do disposto nos incisos II e III do caput, poderão ser celebrados contratos, convênios ou outros instrumentos de colaboração com pessoas jurídicas de direito público ou privado, que atuem na criação e no desenvolvimento de cooperativas ou de outras formas de associação de catadores de materiais reutilizáveis e recicláveis, observada a legislação vigente.

\section{TÍTULO VI}

\section{DOS PLANOS DE RESÍDUOS SÓLIDOS}

\section{CAPÍTULO I}

\section{DAS DISPOSIÇÕES GERAIS}

Art. 45. São planos de resíduos sólidos:

I - o Plano Nacional de Resíduos Sólidos;

II - os planos estaduais de resíduos sólidos;

III - os planos microrregionais de resíduos sólidos e os planos de resíduos sólidos de regiões metropolitanas ou aglomerações urbanas;

IV - os planos intermunicipais de resíduos sólidos;

V - os planos municipais de gestão integrada de resíduos sólidos; e

VI - os planos de gerenciamento de resíduos sólidos.

§ 1ํO Ministério do Meio Ambiente e os demais órgãos competentes darão ampla publicidade, inclusive por meio da rede mundial de computadores, à proposta preliminar, aos estudos que a fundamentaram, ao resultado das etapas de formulação e ao conteúdo dos planos referidos no Capítulo II deste Título, bem como assegurarão o controle social na sua 
formulação, implementação e operacionalização, observado o disposto na Lei $n^{0} 10.650$, de 16 de abril de 2003, e na Lei n $^{\circ} 11.445$, de 2007.

$\S 2^{\circ}$ Os planos de gerenciamento de resíduos da construção civil serão regidos pelas normas estabelecidas pelos órgãos competentes do SISNAMA.

\section{CAPÍTULO II}

\section{DOS PLANOS DE RESÍDUOS SÓLIDOS ELABORADOS PELO PODER PÚBLICO}

\section{Seção I}

\section{Do Plano Nacional de Resíduos Sólidos}

Art. 46. O Plano Nacional de Resíduos Sólidos será elaborado pela União, sob a coordenação do Ministério do Meio Ambiente, com vigência por prazo indeterminado e horizonte de vinte anos, devendo ser atualizado a cada quatro anos.

Art. 47. A elaboração do Plano Nacional de Resíduos Sólidos deverá ser feita de acordo com o seguinte procedimento:

I - formulação e divulgação da proposta preliminar em até cento e oitenta dias, contados a partir da publicação deste Decreto, acompanhada dos estudos que a fundamentam;

II - submissão da proposta à consulta pública, pelo prazo mínimo de sessenta dias, contados da data da sua divulgação;

III - realização de, no mínimo, uma audiência pública em cada região geográfica do País e uma audiência pública de âmbito nacional, no Distrito Federal, simultaneamente ao período de consulta pública referido no inciso II;

IV - apresentação da proposta daquele Plano, incorporadas as contribuições advindas da consulta e das audiências públicas, para apreciação dos Conselhos Nacionais de Meio Ambiente, das Cidades, de Recursos Hídricos, de Saúde e de Política Agrícola; e

V - encaminhamento pelo Ministro de Estado do Meio Ambiente ao Presidente da República da proposta de decreto que aprova aquele Plano.

\section{Seção II}

\section{Dos Planos Estaduais e dos Planos Regionais de Resíduos Sólidos}

Art. 48. Os planos estaduais de resíduos sólidos serão elaborados com vigência por prazo indeterminado, horizonte de atuação de vinte anos e deverão ser atualizados ou revistos a cada quatro anos.

Parágrafo único. Os planos estaduais de resíduos sólidos devem abranger todo o território do respectivo Estado e atender ao conteúdo mínimo previsto no art. 17 da Lei ${ }^{\circ}$ 12.305 , de 2010. 
Art. 49. Além dos planos estaduais, os Estados poderão elaborar planos microrregionais de resíduos sólidos, bem como planos de regiões metropolitanas ou aglomerações urbanas.

$\S 1^{\mathrm{O}} \mathrm{Na}$ elaboração e implementação dos planos referidos no caput, os Estados deverão assegurar a participação de todos os Municípios que integram a respectiva microrregião, região metropolitana ou aglomeração urbana.

$\S 2^{\circ}$ O conteúdo dos planos referidos no caput deverá ser estabelecido em conjunto com os Municípios que integram a respectiva microrregião, região metropolitana ou aglomeração urbana, não podendo ser excluída ou substituída qualquer das prerrogativas atinentes aos Municípios.

\section{Seção III}

\section{Dos Planos Municipais de Gestão Integrada de Resíduos Sólidos}

Art. 50. Os planos municipais de gestão integrada de resíduos sólidos serão elaborados consoante o disposto no art. 19 da Lei $\mathrm{n}^{\circ} 12.305$, de 2010.

$\S 1^{\text {o }}$ Os planos municipais de gestão integrada de resíduos sólidos deverão ser atualizados ou revistos, prioritariamente, de forma concomitante com a elaboração dos planos plurianuais municipais.

$\S 2^{\circ}$ Os planos municipais de gestão integrada de resíduos sólidos deverão identificar e indicar medidas saneadoras para os passivos ambientais originados, entre outros, de:

I - áreas contaminadas, inclusive lixões e aterros controlados; e

II - empreendimentos sujeitos à elaboração de planos de gerenciamento de resíduos sólidos.

Art. 51. Os Municípios com população total inferior a vinte mil habitantes, apurada com base nos dados demográficos do censo mais recente da Fundação Instituto Brasileiro de Geografia Estatística - IBGE, poderão adotar planos municipais simplificados de gestão integrada de resíduos sólidos.

$\S 1$ ํ Os planos municipais simplificados de gestão integrada de resíduos sólidos referidos no caput deverão conter:

I - diagnóstico da situação dos resíduos sólidos gerados no respectivo território, com a indicação da origem, do volume e da massa, a caracterização dos resíduos e as formas de destinação e disposição final adotadas;

II - identificação das áreas favoráveis para disposição final ambientalmente adequada de rejeitos, observado o plano diretor de que trata o $\S 1^{\circ}$ do art. 182 da Constituição e o zoneamento ambiental, quando houver; 
III - identificação da possibilidade de implantação de soluções consorciadas ou compartilhadas com outros Municípios, considerando a economia de escala, a proximidade dos locais estabelecidos e as formas de prevenção dos riscos ambientais;

IV - identificação dos resíduos sólidos e dos geradores sujeitos ao plano de gerenciamento ou ao sistema de logística reversa, conforme os arts. 20 e $\underline{33 \text { da Lei } n^{\circ}}$ 12.305, de 2010, observadas as disposições deste Decreto e as normas editadas pelos órgãos do SISNAMA e do SNVS;

V - procedimentos operacionais e especificações mínimas a serem adotadas nos serviços públicos de limpeza urbana e de manejo de resíduos sólidos, incluída a disposição final ambientalmente adequada de rejeitos, em consonância com o disposto na Lei $\mathrm{n}^{\circ}$

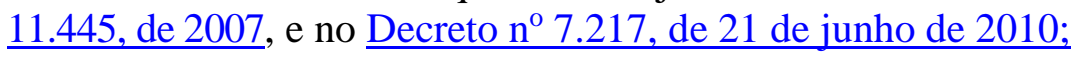

VI - regras para transporte e outras etapas do gerenciamento de resíduos sólidos de que trata o art. 20 da Lei $\mathrm{n}^{\circ} 12.305$, de 2010, observadas as normas editadas pelos órgãos do SISNAMA e do SNVS, bem como as demais disposições previstas na legislação federal e estadual;

VII - definição das responsabilidades quanto à sua implementação e operacionalização pelo Poder Público, incluídas as etapas do plano de gerenciamento de resíduos sólidos;

VIII - programas e ações de educação ambiental que promovam a não geração, a redução, a reutilização, a coleta seletiva e a reciclagem de resíduos sólidos;

IX - programas e ações voltadas à participação de cooperativas e associações de catadores de materiais reutilizáveis e recicláveis formadas por pessoas físicas de baixa renda, quando houver;

X - sistema de cálculo dos custos da prestação dos serviços públicos de limpeza urbana e de manejo de resíduos sólidos, bem como a forma de cobrança desses serviços, observado o disposto na Lei $\mathrm{n}^{\circ} 11.445$, de 2007;

XI - metas de coleta seletiva e reciclagem dos resíduos;

XII - descrição das formas e dos limites da participação do Poder Público local na coleta seletiva e na logística reversa, respeitado o disposto no art. 33 da Lei $\mathrm{n}^{\circ} 12.305$, de $\underline{2010}$, e de outras ações relativas à responsabilidade compartilhada pelo ciclo de vida dos produtos;

XIII - identificação de áreas de disposição inadequada de resíduos e áreas contaminadas e respectivas medidas saneadoras; e

XIV - periodicidade de sua revisão.

$\S 2^{\circ}$ O disposto neste artigo não se aplica aos Municípios:

I - integrantes de áreas de especial interesse turístico; 
II - inseridos na área de influência de empreendimentos ou atividades com significativo impacto ambiental de âmbito regional ou nacional; ou

III - cujo território abranja, total ou parcialmente, unidades de conservação.

Art. 52. Os Municípios que optarem por soluções consorciadas intermunicipais para gestão dos resíduos sólidos estão dispensados da elaboração do plano municipal de gestão integrada de resíduos sólidos, desde que o plano intermunicipal atenda ao conteúdo mínimo previsto no art. 19 da Lei $\mathrm{n}^{\circ} 12.305$, de 2010.

\section{Seção IV}

Da Relação entre os Planos de Resíduos Sólidos e dos Planos de Saneamento Básico no que

Tange ao Componente de Limpeza Urbana e Manejo de Resíduos Sólidos Urbanos

Art. 53. Os serviços públicos de limpeza urbana e de manejo de resíduos sólidos urbanos, compostos pelas atividades mencionadas no art. $3^{\circ}$, inciso I, alínea "c", e no art. $7^{\circ}$ da Lei $\mathrm{n}^{\circ} 11.445$, de 2007, deverão ser prestados em conformidade com os planos de saneamento básico previstos na referida lei e no Decreto $\mathrm{n}^{\circ} 7.217$, de 2010.

Art. 54. No caso dos serviços mencionados no art. 53, os planos de resíduos sólidos deverão ser compatíveis com os planos de saneamento básico previstos na Lei $\mathrm{n}^{\circ} 11.445$, de $\underline{2007}$, e no Decreto $\mathrm{n}^{\circ}$ 7.217, de 2010, sendo que:

I - o componente de limpeza urbana e manejo de resíduos sólidos urbanos do Plano Nacional de Resíduos Sólidos deverá atender ao conteúdo mínimo previsto no art. 52, inciso I, da Lei $\mathrm{n}^{\circ} 11.445$, de 2007, e no art. 15 da Lei $\mathrm{n}^{\circ} 12.305$, de 2010; e

II - o componente de limpeza urbana e manejo de resíduos sólidos urbanos dos planos municipais de gestão integrada de resíduos sólidos deverá atender ao conteúdo mínimo previsto no art. 19 da Lei n ${ }^{\circ} 11.445$, de 2007, e no art. 19 da Lei ${ }^{\circ} 12.305$, de 2010.

$\S$ 1ํㅡ O Plano Nacional de Resíduos Sólidos deverá ser elaborado de forma articulada entre o Ministério do Meio Ambiente e os demais órgãos e entidades federais competentes, sendo obrigatória a participação do Ministério das Cidades na avaliação da compatibilidade do referido Plano com o Plano Nacional de Saneamento Básico.

$\S 2^{\circ}$ O componente de limpeza urbana e manejo de resíduos sólidos urbanos dos planos municipais de gestão integrada de resíduos sólidos poderá estar inserido nos planos de saneamento básico previstos no art. 19 da Lei $\mathrm{n}^{\circ} 11.445$, de 2007, devendo ser respeitado o conteúdo mínimo referido no art. 19 da Lei ${ }^{\circ} 12.305$, de 2010, ou o disposto no art. 51, conforme o caso.

\section{CAPÍTULO III}

DOS PLANOS DE GERENCIAMENTO DE RESÍDUOS SÓLIDOS 
Das Regras Aplicáveis aos Planos de Gerenciamento de Resíduos Sólidos

Art. 55. Os empreendimentos sujeitos à elaboração de plano de gerenciamento de resíduos sólidos localizados em um mesmo condomínio, Município, microrregião, região metropolitana ou aglomeração urbana, que exerçam atividades características de um mesmo setor produtivo e que possuam mecanismos formalizados de governança coletiva ou de cooperação em atividades de interesse comum, poderão optar pela apresentação do referido plano de forma coletiva e integrada.

Parágrafo único. O plano de gerenciamento de resíduos sólidos apresentado na forma do caput deverá conter a indicação individualizada das atividades e dos resíduos sólidos gerados, bem como as ações e responsabilidades atribuídas a cada um dos geradores.

Art. 56. Os responsáveis pelo plano de gerenciamento de resíduos sólidos deverão disponibilizar ao órgão municipal competente, ao órgão licenciador do SISNAMA e às demais autoridades competentes, com periodicidade anual, informações completas e atualizadas sobre a implementação e a operacionalização do plano sob sua responsabilidade, consoante as regras estabelecidas pelo órgão coordenador do Sistema Nacional de Informações Sobre a Gestão dos Resíduos Sólidos-SINIR, por meio eletrônico.

Art. 57. No processo de aprovação do plano de gerenciamento de resíduos sólidos, será assegurada a utilização dos subprodutos e resíduos de valor econômico não descartados, de origem animal ou vegetal, referidos na Lei $\mathrm{n}^{\circ} 8.171$, de 17 de janeiro de 1991, e na Lei ${ }^{\circ} 9.972$, de 25 de maio de 2000, como insumos de cadeias produtivas.

Parágrafo único. Será ainda assegurado o aproveitamento de biomassa na produção de energia e o rerrefino de óleos lubrificantes usados, nos termos da legislação vigente.

\section{Seção II}

Do Conteúdo dos Planos de Gerenciamento de Resíduos Sólidos em Relação à Participação das Cooperativas e outras Formas de Associação de Catadores de Materiais Recicláveis

Art. 58. O plano de gerenciamento de resíduos sólidos dos empreendimentos listados no art. 20 da Lei $\mathrm{n}^{\circ} 12.305$, de 2010 , poderá prever a participação de cooperativas ou de associações de catadores de materiais recicláveis no gerenciamento dos resíduos sólidos recicláveis ou reutilizáveis, quando:

I - houver cooperativas ou associações de catadores capazes técnica e operacionalmente de realizar o gerenciamento dos resíduos sólidos;

II - utilização de cooperativas e associações de catadores no gerenciamento dos resíduos sólidos for economicamente viável; e

III - não houver conflito com a segurança operacional do empreendimento. 
Art. 59. No atendimento ao previsto no art. 58, o plano de gerenciamento de resíduos sólidos deverá especificar as atividades atribuídas às cooperativas e associações, considerando o conteúdo mínimo previsto no art. 21 da Lei n ${ }^{\circ} 12.305$, de 2010.

\section{Seção III}

Dos Planos de Gerenciamento de Resíduos Sólidos

Relativos às Microempresas e Empresas de Pequeno Porte

Art. 60. As microempresas e empresas de pequeno porte, assim consideradas as referidas nos incisos I e II do art. $3^{\circ}$ da Lei Complementar $n^{\circ} 123$, de 14 de dezembro de 2006, que gerem apenas resíduos sólidos domiciliares ou equiparados pelo poder público municipal, nos termos do parágrafo único do art. 13 da Lei $\mathrm{n}^{-}$12.305, de 2010, estão dispensadas de apresentar o plano de gerenciamento de resíduos sólidos.

Art. 61. O plano de gerenciamento de resíduos sólidos das microempresas e empresas de pequeno porte, quando exigível, poderá ser inserido no plano de gerenciamento de empresas com as quais operam de forma integrada, desde que estejam localizadas na área de abrangência da mesma autoridade de licenciamento ambiental.

Parágrafo único. Os planos de gerenciamento de resíduos sólidos apresentados na forma do caput conterão a indicação individualizada das atividades e dos resíduos sólidos gerados, bem como as ações e responsabilidades atribuídas a cada um dos empreendimentos.

Art. 62. Os planos de gerenciamento de resíduos sólidos das microempresas e empresas de pequeno porte poderão ser apresentados por meio de formulário simplificado, definido em ato do Ministério do Meio Ambiente, que deverá conter apenas as informações e medidas previstas no art. 21 da Lei $n^{\circ} 12.305$, de 2010.

Art. 63. O disposto nesta Seção não se aplica às microempresas e empresas de pequeno porte geradoras de resíduos perigosos.

\section{TÍTULO VII}

\section{DOS RESÍDUOS PERIGOSOS}

\section{CAPÍTULO I}

\section{DAS DISPOSIÇÕES GERAIS}

Art. 64. Consideram-se geradores ou operadores de resíduos perigosos empreendimentos ou atividades:

I - cujo processo produtivo gere resíduos perigosos;

II - cuja atividade envolva o comércio de produtos que possam gerar resíduos perigosos e cujo risco seja significativo a critério do órgão ambiental; 
III - que prestam serviços que envolvam a operação com produtos que possam gerar resíduos perigosos e cujo risco seja significativo a critério do órgão ambiental;

IV - que prestam serviços de coleta, transporte, transbordo, armazenamento, tratamento, destinação e disposição final de resíduos ou rejeitos perigosos; ou

$\mathrm{V}$ - que exercerem atividades classificadas em normas emitidas pelos órgãos do SISNAMA, SNVS ou SUASA como geradoras ou operadoras de resíduos perigosos.

Art. 65. As pessoas jurídicas que operam com resíduos perigosos, em qualquer fase do seu gerenciamento, são obrigadas a elaborar plano de gerenciamento de resíduos perigosos e submetê-lo ao órgão competente do SISNAMA e, quando couber, do SNVS e do SUASA, observadas as exigências previstas neste Decreto ou em normas técnicas específicas.

Parágrafo único. O plano de gerenciamento de resíduos perigosos poderá ser inserido no plano de gerenciamento de resíduos sólidos.

Art. 66. A instalação e o funcionamento de empreendimento ou atividade que gere ou opere com resíduos perigosos somente podem ser autorizados ou licenciados pelas autoridades competentes se o responsável comprovar, no mínimo, capacidade técnica e econômica, além de condições para prover os cuidados necessários ao gerenciamento desses resíduos.

Parágrafo único. Para fins de comprovação de capacidade técnica e econômica prevista no caput, os referidos empreendimentos ou atividades deverão:

I - dispor de meios técnicos e operacionais adequados para o atendimento da respectiva etapa do processo de gerenciamento dos resíduos sob sua responsabilidade, observadas as normas e outros critérios estabelecidos pelo órgão ambiental competente; e

II - apresentar, quando da concessão ou renovação do licenciamento ambiental, as demonstrações financeiras do último exercício social, a certidão negativa de falência, bem como a estimativa de custos anuais para o gerenciamento dos resíduos perigosos, ficando resguardado o sigilo das informações apresentadas.

Art. 67. No licenciamento ambiental de empreendimentos ou atividades que operem com resíduos perigosos, o órgão licenciador do SISNAMA pode exigir a contratação de seguro de responsabilidade civil por danos causados ao meio ambiente ou à saúde pública, observadas as regras sobre cobertura e os limites máximos de contratação estabelecidos pelo Conselho Nacional de Seguros Privados - CNSP.

Parágrafo único. A aplicação do disposto no caput deverá considerar o porte e as características da empresa.

\section{CAPÍTULO II}

DO CADASTRO NACIONAL DE OPERADORES DE RESÍDUOS PERIGOSOS 
Art. 68. As pessoas jurídicas que operam com resíduos perigosos, em qualquer fase de seu gerenciamento, são obrigadas a se cadastrar no Cadastro Nacional de Operadores de Resíduos Perigosos.

Parágrafo único. As pessoas jurídicas referidas no caput deverão indicar responsável técnico pelo gerenciamento dos resíduos perigosos, devidamente habilitado, cujos dados serão mantidos atualizados no cadastro.

Art. 69. O Instituto Brasileiro do Meio Ambiente e dos Recursos Naturais Renováveis - IBAMA será responsável por coordenar o Cadastro Nacional de Operadores de Resíduos Perigosos, que será implantado de forma conjunta pelas autoridades federais, estaduais e municipais.

$\S 1^{\circ}$ O IBAMA deverá adotar medidas visando assegurar a disponibilidade e a publicidade do cadastro referido no caput aos órgãos e entidades interessados.

$\S 2^{\circ}$ O IBAMA deverá promover a integração do Cadastro Nacional de Operadores de Resíduos Perigosos com o Cadastro Técnico Federal de Atividades Potencialmente Poluidoras ou Utilizadoras de Recursos Ambientais e com o SINIR.

Art. 70. O Cadastro Nacional de Operadores de Resíduos Perigosos será composto com base nas informações constantes nos Planos de Gerenciamento de Resíduos Perigosos, no relatório específico anual do Cadastro Técnico Federal de Atividades Potencialmente Poluidoras ou Utilizadoras de Recursos Ambientais, bem como nas informações sobre a quantidade, a natureza e a destinação temporária ou final dos resíduos sob responsabilidade da respectiva pessoa jurídica, entre outras fontes.

\section{TÍTULO VIII}

\section{DO SISTEMA NACIONAL DE INFORMAÇÕES}

\section{SOBRE A GESTÃO DOS RESÍDUOS SÓLIDOS - SINIR}

Art. 71. Fica instituído o Sistema Nacional de Informações Sobre a Gestão dos Resíduos Sólidos-SINIR, sob a coordenação e articulação do Ministério do Meio Ambiente, com a finalidade de:

I - coletar e sistematizar dados relativos à prestação dos serviços públicos e privados de gestão e gerenciamento de resíduos sólidos, inclusive dos sistemas de logística reversa implantados;

II - promover o adequado ordenamento para a geração, armazenamento, sistematização, compartilhamento, acesso e disseminação dos dados e informações de que trata o inciso I;

III - classificar os dados e informações de acordo com a sua importância e confidencialidade, em conformidade com a legislação vigente; 
IV - disponibilizar estatísticas, indicadores e outras informações relevantes, inclusive visando à caracterização da demanda e da oferta de serviços públicos de gestão e gerenciamento de resíduos sólidos;

V - permitir e facilitar o monitoramento, a fiscalização e a avaliação da eficiência da gestão e gerenciamento de resíduos sólidos nos diversos níveis, inclusive dos sistemas de logística reversa implantados;

VI - possibilitar a avaliação dos resultados, dos impactos e o acompanhamento das metas dos planos e das ações de gestão e gerenciamento de resíduos sólidos nos diversos níveis, inclusive dos sistemas de logística reversa implantados;

VII - informar a sociedade sobre as atividades realizadas na implementação da Política Nacional de Resíduos Sólidos;

VIII - disponibilizar periodicamente à sociedade o diagnóstico da situação dos resíduos sólidos no País, por meio do Inventário Nacional de Resíduos Sólidos; e

IX - agregar as informações sob a esfera de competência da União, Estados, Distrito Federal e Municípios.

Parágrafo único. O SINIR deverá ser implementado no prazo máximo de dois anos, contados da publicação deste Decreto.

Art. 72. O SINIR será estruturado de modo a conter as informações fornecidas:

I - pelo Cadastro Nacional de Operadores de Resíduos Perigosos;

II - pelo Cadastro Técnico Federal de Atividades Potencialmente Poluidoras ou Utilizadoras de Recursos Ambientais;

III - pelo Cadastro Técnico Federal de Atividades e Instrumentos de Defesa Ambiental;

IV - pelos órgãos públicos competentes para a elaboração dos planos de resíduos sólidos referidos no art. 14 da Lei n ${ }^{\circ} 12.305$, de 2010;

$\mathrm{V}$ - pelos demais sistemas de informações que compõem o Sistema Nacional de Informações sobre Meio Ambiente - SINIMA; e

VI - pelo Sistema Nacional de Informações em Saneamento Básico - SINISA, no que se refere aos serviços públicos de limpeza urbana e manejo de resíduos sólidos.

Art. 73. A implementação do SINIR dar-se-á mediante:

I - articulação com o SINIMA e com o Sistema Nacional de Informações de Recursos Hídricos - SNIRH; 
II - articulação com os órgãos integrantes do SISNAMA, para interoperabilidade entre os diversos sistemas de informação existentes e para o estabelecimento de padrões e ontologias para as unidades de informação componentes do SINIR;

III - integração ao SINISA no tocante aos serviços públicos de limpeza urbana e manejo de resíduos sólidos urbanos; e

IV - sistematização de dados, disponibilização de estatísticas e indicadores referentes à gestão e gerenciamento de resíduos sólidos.

Art. 74. O Ministério do Meio Ambiente apoiará os Estados, o Distrito Federal, os Municípios e os respectivos órgãos executores do SISNAMA na organização das informações, no desenvolvimento dos instrumentos e no financiamento das ações voltadas à implantação e manutenção do SINIR.

$\S 1^{\text {o }}$ O Ministério do Meio Ambiente, os Estados, o Distrito Federal e os Municípios, de forma conjunta, organizarão e manterão a infraestrutura necessária para receber, analisar, classificar, sistematizar, consolidar e divulgar dados e informações qualitativas e quantitativas sobre a gestão de resíduos sólidos.

$\S 2^{2}$ Os Estados, o Distrito Federal e os Municípios disponibilizarão anualmente ao SINIR as informações necessárias sobre os resíduos sólidos sob sua esfera de competência.

§ 3o Os planos de gestão de resíduos sólidos deverão ser disponibilizados pelos respectivos responsáveis no SINIR.

Art. 75. A coleta e sistematização de dados, a disponibilização de estatísticas e indicadores, o monitoramento e a avaliação da eficiência da prestação dos serviços públicos de limpeza urbana e manejo de resíduos sólidos serão realizados no âmbito do SINISA, nos termos do art. 53 da Lei n ${ }^{0} 11.445$, de 2007.

$\S 1^{\circ}$ O SINIR utilizará as informações do SINISA referentes às atividades previstas no caput.

$\S 2^{2}$ O Ministério do Meio Ambiente e o Ministério das Cidades deverão adotar as medidas necessárias para assegurar a integração entre o SINIR e o SINISA.

Art. 76. Os dados, informações, relatórios, estudos, inventários e instrumentos equivalentes que se refiram à regulação ou à fiscalização dos serviços relacionados à gestão dos resíduos sólidos, bem como aos direitos e deveres dos usuários e operadores, serão disponibilizados pelo SINIR na rede mundial de computadores.

$\S 1^{\mathrm{o}}$ A publicidade das informações divulgadas por meio do SINIR observará o sigilo comercial, industrial, financeiro ou de qualquer outro tipo protegido por lei.

$\S 2^{\mathrm{o}}$ As pessoas físicas e jurídicas que fornecerem informações de caráter sigiloso aos órgãos e entidades da administração pública deverão indicar essa circunstância, de forma expressa e fundamentada, a fim de que seja resguardado o sigilo a que se refere o $\S 1$. 


\section{TÍTULO IX}

\section{DA EDUCAÇÃO AMBIENTAL NA GESTÃO DOS RESÍDUOS SÓLIDOS}

Art. 77. A educação ambiental na gestão dos resíduos sólidos é parte integrante da Política Nacional de Resíduos Sólidos e tem como objetivo o aprimoramento do conhecimento, dos valores, dos comportamentos e do estilo de vida relacionados com a gestão e o gerenciamento ambientalmente adequado dos resíduos sólidos.

§ 1ํ A educação ambiental na gestão dos resíduos sólidos obedecerá às diretrizes gerais fixadas na Lei $\mathrm{n}^{\circ} 9.795$, de 1999, e no Decreto $\mathrm{n}^{\circ} 4.281$, de 25 de junho de 2002, bem como às regras específicas estabelecidas na Lei $\mathrm{n}^{0} 12.305$, de 2010, e neste Decreto.

$\S 2^{\circ}$ O Poder Público deverá adotar as seguintes medidas, entre outras, visando o cumprimento do objetivo previsto no caput:

I - incentivar atividades de caráter educativo e pedagógico, em colaboração com entidades do setor empresarial e da sociedade civil organizada;

II - promover a articulação da educação ambiental na gestão dos resíduos sólidos com a Política Nacional de Educação Ambiental;

III - realizar ações educativas voltadas aos fabricantes, importadores, comerciantes e distribuidores, com enfoque diferenciado para os agentes envolvidos direta e indiretamente com os sistemas de coleta seletiva e logística reversa;

IV - desenvolver ações educativas voltadas à conscientização dos consumidores com relação ao consumo sustentável e às suas responsabilidades no âmbito da responsabilidade compartilhada de que trata a Lei $\mathrm{n}^{\circ} 12.305$, de 2010;

V - apoiar as pesquisas realizadas por órgãos oficiais, pelas universidades, por organizações não governamentais e por setores empresariais, bem como a elaboração de estudos, a coleta de dados e de informações sobre o comportamento do consumidor brasileiro;

VI - elaborar e implementar planos de produção e consumo sustentável;

VII - promover a capacitação dos gestores públicos para que atuem como multiplicadores nos diversos aspectos da gestão integrada dos resíduos sólidos; e

VIII - divulgar os conceitos relacionados com a coleta seletiva, com a logística reversa, com o consumo consciente e com a minimização da geração de resíduos sólidos.

$\S 3^{\circ}$ As ações de educação ambiental previstas neste artigo não excluem as responsabilidades dos fornecedores referentes ao dever de informar o consumidor para o cumprimento dos sistemas de logística reversa e coleta seletiva instituídos.

\section{TÍTULO X}


Art. 78. A elaboração dos planos de resíduos sólidos previstos no art. 45 é condição, nos termos do art. 55 da Lei n ${ }^{\circ} 12.305$, de 2010, para que os Estados, o Distrito Federal e os Municípios tenham acesso a recursos da União ou por ela controlados, bem como para que sejam beneficiados por incentivos ou financiamentos de entidades federais de crédito ou fomento destinados, no âmbito de suas respectivas competências:

I - a empreendimentos e serviços relacionados à gestão de resíduos sólidos; ou

II - à limpeza urbana e manejo de resíduos sólidos.

Parágrafo único. O acesso aos recursos mencionados no caput fica condicionado à comprovação da regularidade fiscal perante a União.

Art. 79. A União e os órgãos ou entidades a ela vinculados darão prioridade no acesso aos recursos mencionados no art. 78:

I - aos Estados que instituírem microrregiões, consoante o $\S 3^{\circ}$ do art. 25 da

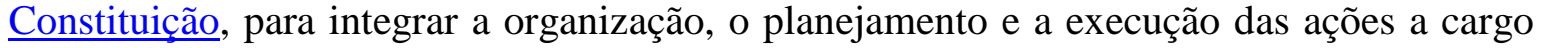
de Municípios limítrofes na gestão dos resíduos sólidos;

II - ao Distrito Federal e aos Municípios que:

a) optarem por soluções consorciadas intermunicipais para a gestão dos resíduos sólidos, incluída a elaboração e implementação de plano intermunicipal, ou que se inserirem de forma voluntária nos planos microrregionais de resíduos sólidos referidos no art. 16 da Lei $\mathrm{n}^{\circ} 12.305$, de 2010; ou

b) implantarem a coleta seletiva com a participação de cooperativas ou outras formas de associação de catadores de materiais reutilizáveis e recicláveis formadas por pessoas físicas de baixa renda; e

III - aos consórcios públicos, constituídos na forma da Lei n ${ }^{0} 11.105$, de 2005.

$\S 1^{\underline{o}}$ Os critérios de prioridade no acesso aos recursos previstos no caput não excluem outros critérios definidos em programas específicos instituídos pelo Poder Público Federal.

$\S 2^{\mathrm{o}}$ Os Estados, o Distrito Federal, os Municípios e os consórcios públicos deverão atender às seguintes condições, entre outras estabelecidas na legislação vigente, para serem beneficiados com a prioridade no acesso aos recursos prevista do caput:

I - adotar, de forma efetiva, soluções regionalizadas para a organização, planejamento e execução das ações na gestão dos resíduos sólidos, no que concerne aos incisos I, II, alínea "a", e III do caput; e

II - manter os dados e informações atualizadas no SINIR, o que será comprovado mediante a apresentação de certidão de regularidade emitida pelo órgão coordenador do referido sistema.

\section{TÍTULO XI}




\section{DOS INSTRUMENTOS ECONÔMICOS}

Art. 80. As iniciativas previstas no art. 42 da Lei $\mathrm{n}^{\circ} 12.305$, de 2010 , serão fomentadas por meio das seguintes medidas indutoras:

I - incentivos fiscais, financeiros e creditícios;

II - cessão de terrenos públicos;

III - destinação dos resíduos recicláveis descartados pelos órgãos e entidades da administração pública federal às associações e cooperativas dos catadores de materiais recicláveis, nos termos do Decreto $n^{0} 5.940$, de 25 de outubro de 2006;

IV - subvenções econômicas;

V - fixação de critérios, metas, e outros dispositivos complementares de sustentabilidade ambiental para as aquisições e contratações públicas;

VI - pagamento por serviços ambientais, nos termos definidos na legislação; e

VII - apoio à elaboração de projetos no âmbito do Mecanismo de Desenvolvimento Limpo - MDL ou quaisquer outros mecanismos decorrentes da Convenção Quadro de Mudança do Clima das Nações Unidas.

Parágrafo único. O Poder Público poderá estabelecer outras medidas indutoras além das previstas no caput.

Art. 81. As instituições financeiras federais poderão também criar linhas especiais de financiamento para:

I - cooperativas ou outras formas de associação de catadores de materiais reutilizáveis e recicláveis, com o objetivo de aquisição de máquinas e equipamentos utilizados na gestão de resíduos sólidos;

II - atividades destinadas à reciclagem e ao reaproveitamento de resíduos sólidos, bem como atividades de inovação e desenvolvimento relativas ao gerenciamento de resíduos sólidos; e

III - atendimento a projetos de investimentos em gerenciamento de resíduos sólidos.

$$
\text { TÍTULO XII }
$$

\section{DAS DISPOSIÇÕES FINAIS}

Art. 82. Para efeitos do inciso I do art. 47 da Lei $\mathrm{n}^{\circ} 12.305$, de 2010, o deslocamento de material do leito de corpos d'água por meio de dragagem não se considera lançamento, devendo ser objeto de licenciamento ou autorização do órgão ambiental competente. 
Art. 83. Quando decretada emergência sanitária, poderá ser realizada a queima de resíduos a céu aberto, desde que autorizada e acompanhada pelos órgãos competentes do SISNAMA, do SNVS e, quando couber, do SUASA.

Art. 84. O art. 62 do Decreto no 6.514, de 22 de julho de 2008, passa a vigorar com a seguinte redação:

“Art. 62.

IX - lançar resíduos sólidos ou rejeitos em praias, no mar ou quaisquer recursos hídricos;

$\mathrm{X}$ - lançar resíduos sólidos ou rejeitos in natura a céu aberto, excetuados os resíduos de mineração;

XI - queimar resíduos sólidos ou rejeitos a céu aberto ou em recipientes, instalações e equipamentos não licenciados para a atividade;

XII - descumprir obrigação prevista no sistema de logística reversa implantado nos termos da Lei $\mathrm{n}^{-}$12.305, de 2010, consoante as responsabilidades específicas estabelecidas para o referido sistema;

XIII - deixar de segregar resíduos sólidos na forma estabelecida para a coleta seletiva, quando a referida coleta for instituída pelo titular do serviço público de limpeza urbana e manejo de resíduos sólidos;

XIV - destinar resíduos sólidos urbanos à recuperação energética em desconformidade com

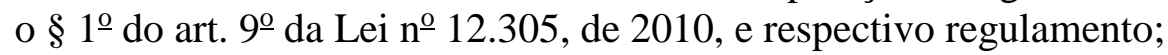

$\mathrm{XV}$ - deixar de manter atualizadas e disponíveis ao órgão municipal competente e a outras autoridades informações completas sobre a realização das ações do sistema de logística reversa sobre sua responsabilidade;

XVI - não manter atualizadas e disponíveis ao órgão municipal competente, ao órgão licenciador do SISNAMA e a outras autoridades, informações completas sobre a implementação e a operacionalização do plano de gerenciamento de resíduos sólidos sob sua responsabilidade; $\mathrm{e}$

XVII - deixar de atender às regras sobre registro, gerenciamento e informação previstos no $\S 2^{\mathrm{o}}$ do art. 39 da Lei $\mathrm{n}^{\mathrm{o}} 12.305$, de 2010.

$\S 1^{\circ}$ As multas de que tratam os incisos I a XI deste artigo serão aplicadas após laudo de constatação.

$\S 2^{0}$ Os consumidores que descumprirem as respectivas obrigações previstas nos sistemas de logística reversa e de coleta seletiva estarão sujeitos à penalidade de advertência.

$\S 3^{\circ}$ No caso de reincidência no cometimento da infração prevista no $\S 2^{\circ}$, poderá ser aplicada a penalidade de multa, no valor de $\mathrm{R} \$ 50,00$ (cinquenta reais) a $\mathrm{R} \$ 500,00$ (quinhentos reais). 
$\S 4^{\circ}$ A multa simples a que se refere o $\S 3^{\circ}$ pode ser convertida em serviços de preservação, melhoria e recuperação da qualidade do meio ambiente.

$\S 5^{\circ}$ Não estão compreendidas na infração do inciso IX as atividades de deslocamento de material do leito de corpos d'água por meio de dragagem, devidamente licenciado ou aprovado.

§ 60 As bacias de decantação de resíduos ou rejeitos industriais ou de mineração, devidamente licenciadas pelo órgão competente do SISNAMA, não são consideradas corpos hídricos para efeitos do disposto no inciso IX.” (NR)

Art. 85. O Decreto $\mathrm{n}^{\mathrm{o}}$ 6.514, de 2008, passa a vigorar acrescido do seguinte artigo:

“Art. 71-A. Importar resíduos sólidos perigosos e rejeitos, bem como os resíduos sólidos cujas características causem dano ao meio ambiente, à saúde pública e animal e à sanidade vegetal, ainda que para tratamento, reforma, reuso, reutilização ou recuperação:

Multa de R \$ 500,00 (quinhentos reais) a R \$ 10.000.000,00 (dez milhões de reais).” (NR)

Art. 86. Este Decreto entra em vigor na data de sua publicação.

Brasília, 23 de dezembro de 2010; 189ํ da Independência e 122ํㅡ da República.

LUIZ INÁCIO LULA DA SILVA

Luiz Paulo Teles Ferreira Barreto

Guido Mantega

Wagner Gonçalves Rossi

Miguel Jorge

Márcio Pereira Zimmermann

Márcia Helena Carvalho Lopes

Izabella Mônica Vieira Teixeira

Márcio Fortes de Almeida

Este texto não substitui o publicado no DOU de 23.12.2010 - Edição ext 


\title{
DECRETO N N.405, DE 23 DE DEZEMBRO DE $2010 .^{\circ}$
}

\begin{abstract}
Institui o Programa Pró-Catador, denomina Comitê Interministerial para Inclusão Social e Econômica dos Catadores de Materiais Reutilizáveis e Recicláveis o Comitê Interministerial da Inclusão Social de Catadores de Lixo criado pelo Decreto de 11 de setembro de 2003, dispõe sobre sua organização e funcionamento, e dá outras providências.
\end{abstract}

O PRESIDENTE DA REPÚBLICA, no uso da atribuição que lhe confere o art. 84, inciso VI, alínea "a”, da Constituição,

\section{DECRETA:}

Art. 1ํ Fica instituído o Programa Pró-Catador, com a finalidade de integrar e articular as ações do Governo Federal voltadas ao apoio e ao fomento à organização produtiva dos catadores de materiais reutilizáveis e recicláveis, à melhoria das condições de trabalho, à ampliação das oportunidades de inclusão social e econômica e à expansão da coleta seletiva de resíduos sólidos, da reutilização e da reciclagem por meio da atuação desse segmento.

Parágrafo único. Para os fins deste Decreto, consideram-se catadores de materiais reutilizáveis e recicláveis as pessoas físicas de baixa renda que se dedicam às atividades de coleta, triagem, beneficiamento, processamento, transformação e comercialização de materiais reutilizáveis e recicláveis.

Art. $2^{\mathrm{o}} \mathrm{O}$ Programa Pró-Catador tem por objetivo promover e integrar as seguintes ações voltadas aos catadores de materiais reutilizáveis e recicláveis:

I - capacitação, formação e assessoria técnica;

II - incubação de cooperativas e de empreendimentos sociais solidários que atuem na reciclagem;

III - pesquisas e estudos para subsidiar ações que envolvam a responsabilidade compartilhada pelo ciclo de vida dos produtos;

IV - aquisição de equipamentos, máquinas e veículos voltados para a coleta seletiva, reutilização, beneficiamento, tratamento e reciclagem pelas cooperativas e associações de catadores de materiais reutilizáveis e recicláveis; 
V - implantação e adaptação de infraestrutura física de cooperativas e associações de catadores de materiais reutilizáveis e recicláveis;

VI - organização e apoio a redes de comercialização e cadeias produtivas integradas por cooperativas e associações de catadores de materiais reutilizáveis e recicláveis;

VII - fortalecimento da participação do catador de materiais reutilizáveis e recicláveis nas cadeias de reciclagem;

VIII - desenvolvimento de novas tecnologias voltadas à agregação de valor ao trabalho de coleta de materiais reutilizáveis e recicláveis; e

IX - abertura e manutenção de linhas de crédito especiais para apoiar projetos voltados à institucionalização e fortalecimento de cooperativas e associações de catadores de materiais reutilizáveis e recicláveis.

Parágrafo único. As ações do Programa Pró-Catador deverão contemplar recursos para viabilizar a participação dos catadores de materiais reutilizáveis e recicláveis nas atividades desenvolvidas, inclusive para custeio de despesas com deslocamento, estadia e alimentação dos participantes, nas hipóteses autorizadas pela legislação vigente.

Art. 3o O Programa Pró-Catador poderá ser realizado em cooperação com órgãos ou entidades da administração pública federal e órgãos e entidades dos Estados, Distrito Federal e Municípios que a ele aderirem.

$\S 1^{0}$ A adesão voluntária dos entes federados ao Programa Pró-Catador far-se-á por meio de termo de adesão, na forma a ser definida pelo Comitê Interministerial de que trata o art. 6º, implicando a assunção da responsabilidade de promover, na respectiva esfera de competência, as finalidades previstas no caput do art. $1^{\circ}$.

$\S 2^{\underline{0}}$ Aos entes federados que aderirem ao Programa Pró-Catador caberá promover e acompanhar o desenvolvimento de estudos e pesquisas para subsidiar a implantação da coleta seletiva local e regional e outras ações de inclusão social e econômica dos catadores de materiais reutilizáveis e recicláveis.

Art. 4ํ Para fins de execução das ações do Programa Pró-Catador, os órgãos do Governo Federal envolvidos poderão, observada a legislação vigente, firmar convênios, contratos de repasse, acordos de cooperação, termos de parceria, ajustes ou outros instrumentos de colaboração, com:

I - órgãos ou entidades da administração pública federal, dos Estados, do Distrito Federal e dos Municípios;

II - consórcios públicos constituídos nos termos da Lei $\mathrm{n}^{0} 11.107$, de 6 de abril de 2005;

III - cooperativas e associações de catadores de materiais reutilizáveis e recicláveis; e

IV - entidades sem fins lucrativos que atuem na incubação, capacitação, assistência técnica e no desenvolvimento de redes de comercialização, de cooperativas ou de outras 
formas de associação de catadores de materiais reutilizáveis e recicláveis, ou na sua inclusão social e econômica.

Parágrafo único. Os instrumentos de colaboração firmados com órgãos ou entidades dos Estados, do Distrito Federal e dos Municípios poderão prever a aplicação de recursos na gestão do Programa Pró-Catador, possibilitando a manutenção de estrutura técnicoadministrativa adequada nas respectivas esferas do governo.

Art. 5ㅇ $\mathrm{O}$ ingresso das entidades previstas nos incisos III e IV do caput do art. $4^{\circ}$ no Programa Pró-Catador dar-se-á por meio de seleção pública de projetos, nos termos de edital previamente publicado pelos órgãos do Governo Federal dele participantes e avaliado pelo Comitê Interministerial de que trata o art. $6^{\circ}$.

$\S 1^{\mathrm{O}}$ A assinatura dos convênios, contratos de repasse, acordos de cooperação, ajustes ou outros instrumentos de colaboração com as entidades de que tratam os incisos III e IV do caput do art. 4을 cujos projetos forem selecionados com base no procedimento previsto neste artigo, observará a ordem de classificação dos projetos aprovados e a disponibilidade orçamentária e financeira para o exercício.

$\S 2^{\underline{o}}$ A execução dos convênios, contratos de repasse, acordos de cooperação, termos de parceria, ajustes ou instrumentos de colaboração com as entidades cujos projetos forem selecionados nos termos deste artigo será monitorada com base na legislação vigente e no plano de trabalho previstos nos termos do edital publicado pelo órgão do Governo Federal participante do Programa Pró-Catador.

Art. $6^{-}$O Comitê Interministerial da Inclusão Social de Catadores de Lixo, criado pelo Decreto de 11 de setembro de 2003, passa a denominar-se Comitê Interministerial para Inclusão Social e Econômica dos Catadores de Materiais Reutilizáveis e Recicláveis e a reger-se pelas disposições deste Decreto.

$\S 1^{\circ}$ O Comitê Interministerial coordenará a execução e realizará o monitoramento do Programa Pró-Catador.

$\S 2^{\mathrm{o}} \mathrm{O}$ Comitê Interministerial será composto por um representante, titular e suplente, de cada órgão a seguir indicado:

I - Casa Civil da Presidência da República;

II - Ministério da Educação;

III - Ministério da Saúde;

IV - Ministério do Trabalho e Emprego;

V - Ministério da Ciência e Tecnologia;

VI - Ministério do Meio Ambiente;

VII - Ministério do Desenvolvimento Social e Combate à Fome; 
VIII - Ministério das Cidades;

IX - Ministério do Desenvolvimento, Indústria e Comércio Exterior;

X - Ministério da Previdência Social;

XI - Ministério do Turismo;

XII - Ministério do Planejamento, Orçamento e Gestão;

XIII - Ministério de Minas e Energia;

XIV - Ministério da Fazenda;

XV - Secretaria-Geral da Presidência da República; e

XVI - Secretaria de Direitos Humanos da Presidência da República.

$\S 3^{\text {o }}$ Serão convidados a integrar o Comitê Interministerial representantes da Fundação Nacional de Saúde - FUNASA, do Instituto de Pesquisa Econômica Aplicada IPEA, do Banco Nacional de Desenvolvimento Econômico e Social - BNDES, da Caixa Econômica Federal, do Banco do Brasil S.A., da Fundação Banco do Brasil, da Fundação Parque Tecnológico Itaipu, da Petróleo Brasileiro S.A. - Petrobras e das Centrais Elétricas Brasileiras S.A. - Eletrobras.

§ 4ํ O Comitê Interministerial poderá convidar representantes de órgãos da administração pública federal, estadual e municipal e da sociedade civil, para acompanhamento de suas atividades, bem como instituir grupos de trabalho para apreciação de matérias específicas.

$\S 5^{\Theta}$ A coordenação do Comitê Interministerial será exercida em conjunto pelos representantes dos Ministérios do Desenvolvimento Social e Combate à Fome do Meio Ambiente, que deverão prover as condições necessárias para o seu funcionamento.

$\S \sigma^{\Theta}$-Os membros do Comitê Interministerial serão indicados pelos titulares dos érgães representados e designados em portaria interministerial des Ministros de Estado do Desenvolvimento Social e Combate à Fome e do Meio Ambiente.

§ 5ำ A coordenação do Comitê Interministerial será exercida pelo representante da Secretaria-Geral da Presidência da República. (Redação dada pelo Decreto $\mathrm{n}^{\circ} 7.851$, de 2012) Vigência

$\S 6^{\circ}$ Os membros do Comitê Interministerial serão indicados pelos titulares dos órgãos representados e designados em ato dos Ministros de Estado Chefe da SecretariaGeral da Presidência da República e do Meio Ambiente. (Redação dada pelo Decreto ${ }^{\circ}$ 7.851, de 2012) Vigência

§ 7ํㅡ O Comitê Interministerial deverá elaborar o seu regimento interno.

$\S 8^{0}$ A participação no Comitê Interministerial será considerada prestação de serviço público relevante, não remunerada. 
Art. $7^{\mathrm{o}}$ Compete ao Comitê Interministerial:

I - apoiar ações de inclusão social e econômica de catadores de materiais reutilizáveis e recicláveis;

II - articular as políticas setoriais e acompanhar a implementação de ações voltadas à população de catadores de materiais reutilizáveis e recicláveis;

III - definir mecanismos de monitoramento e avaliação da implantação das ações integradas a serem executadas nas municipalidades;

IV - receber, processar, acompanhar e monitorar as informações encaminhadas semestralmente pelas Comissões da Coleta Seletiva Solidária sobre o processo de separação dos resíduos recicláveis e reutilizáveis descartados, na fonte geradora, e sua destinação às associações e cooperativas dos catadores de materiais reutilizáveis e recicláveis, conforme determina o $\$ 3^{\circ}$ do art. $5^{\circ}$ do Decreto $\mathrm{n}^{\circ} 5.940$, de 25 de outubro de $\underline{2006 ;}$

V - auxiliar a União na elaboração das metas do Plano Nacional de Resíduos Sólidos para a eliminação e recuperação de lixões, associadas à inclusão social e à emancipação econômica de catadores de materiais reutilizáveis e recicláveis, de acordo com o inciso V do art. 15 da Lei ${ }^{0} 12.305$, de 2 de agosto de 2010;

VI - estimular a constituição de fóruns e comitês locais para o auxílio dos demais entes federados na elaboração das metas a serem inseridas nos respectivos Planos de Resíduos Sólidos;

VII - propor campanhas educativas e encontros nacionais para promover a cultura de inclusão dos catadores de materiais reutilizáveis e recicláveis nas ações e políticas públicas relativas à gestão de resíduos sólidos;

VIII - acompanhar a elaboração e a tramitação dos atos normativos que compõem o ciclo orçamentário, propondo a inclusão de recursos para ações voltadas ao segmento de catadores de materiais reutilizáveis e recicláveis no orçamento da União;

IX - estimular a participação do setor privado nas ações de inclusão social e econômica de catadores de materiais reutilizáveis e recicláveis;

X - definir plano de ação do Programa Pró-Catador, que deverá orientar a execução de ações a ele relacionadas;

XI - definir critérios de reconhecimento, cadastramento e seleção do público-alvo do Programa Pró-Catador;

XII - definir o conteúdo mínimo do termo de adesão de que trata o $§ 1^{\circ}$ do art. 3ㅜ;

XIII - avaliar os editais de que trata o art. 5ำ, previamente à sua publicação pelos órgãos do Governo Federal que aderirem ao Programa Pró-Catador, bem como os procedimentos definidos para seleção de projetos, acompanhamento, monitoramento e prestação de contas; 
XIV - apresentar, ao final de cada ano, relatório circunstanciado contendo as atividades realizadas no âmbito do Programa Pró-Catador, bem como balanço dos resultados alcançados; e

XV - definir outras ações necessárias à operacionalização do Programa Pró-Catador.

Art. $8^{\ominus}$ As atividades de secretaria- executiva do Comitê Interministerial serã exercidas pelo Ministério do Desenvolvimento Sociale Combate à Fome.

Art. $8^{\text {o }}$ As atividades de secretaria-executiva do Comitê Interministerial serão exercidas pela Secretaria-Geral da Presidência da República, que deverá prover as condições para seu funcionamento. (Redação dada pelo Decreto $\mathrm{n}^{\circ} 7.851$, de 2012) Vigência

Art. 9ํ As despesas decorrentes da implementação e execução do Programa PróCatador advirão das dotações orçamentárias próprias consignadas anualmente nos orçamentos dos órgãos e entidades nele envolvidos, observados os limites de movimentação, de empenho e de pagamento da programação orçamentária e financeira anual.

Art. 10. Este Decreto entra em vigor na data de sua publicação.

Art. 11. Fica revogado o Decreto de 11 de setembro de 2003, que cria o Comitê Interministerial da Inclusão Social de Catadores de Lixo.

Brasília, 23 de dezembro de 2010; 189ํㅜ da Independência e 122ํㅡ da República.

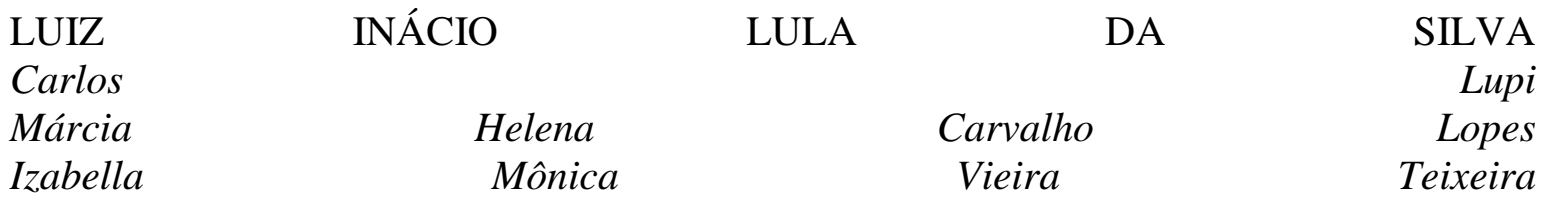

Márcio Fortes de Almeida

Este texto não substitui o publicado no DOU de 23.12.2010 - Edição extra

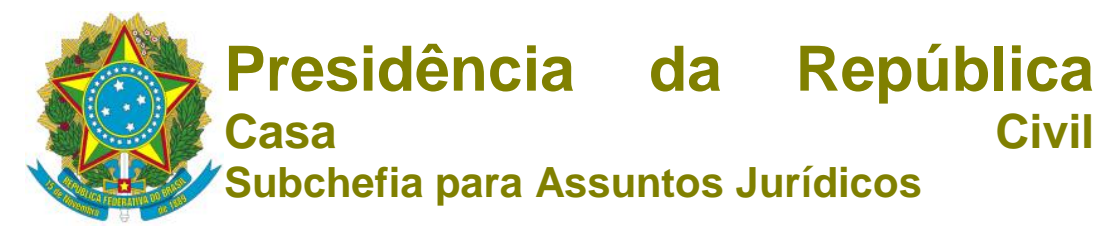

LEI No 12.690, DE 19 DE JULHO DE 2012. 
$\underline{\text { Mensagem de veto }}$

Dispõe sobre a organização e o funcionamento das Cooperativas de Trabalho; institui o Programa Nacional de Fomento às Cooperativas de Trabalho - PRONACOOP; e revoga o parágrafo único do art. 442 da Consolidação das Leis do Trabalho - CLT, aprovada pelo Decreto-Lei no 5.452 , de $1^{\underline{0}}$ de maio de 1943.

A PRESIDENTA DA REPÚBLICA Faço saber que o Congresso Nacional decreta e eu sanciono a seguinte Lei:

\section{CAPÍTULO I}

\section{DAS COOPERATIVAS DE TRABALHO}

Art. 1ํ A Cooperativa de Trabalho é regulada por esta Lei e, no que com ela não colidir, pelas Leis n ${ }^{\text {os }} 5.764$, de 16 de dezembro de 1971, e 10.406, de 10 de janeiro de 2002 -Código Civil.

Parágrafo único. Estão excluídas do âmbito desta Lei:

I - as cooperativas de assistência à saúde na forma da legislação de saúde suplementar;

II - as cooperativas que atuam no setor de transporte regulamentado pelo poder público e que detenham, por si ou por seus sócios, a qualquer título, os meios de trabalho;

III - as cooperativas de profissionais liberais cujos sócios exerçam as atividades em seus próprios estabelecimentos; e

IV - as cooperativas de médicos cujos honorários sejam pagos por procedimento.

Art. 2o Considera-se Cooperativa de Trabalho a sociedade constituída por trabalhadores para o exercício de suas atividades laborativas ou profissionais com proveito comum, autonomia e autogestão para obterem melhor qualificação, renda, situação socioeconômica e condições gerais de trabalho.

$\S 1^{\mathrm{o}}$ A autonomia de que trata o caput deste artigo deve ser exercida de forma coletiva e coordenada, mediante a fixação, em Assembleia Geral, das regras de funcionamento da cooperativa e da forma de execução dos trabalhos, nos termos desta Lei.

$\S 2^{\mathrm{o}}$ Considera-se autogestão o processo democrático no qual a Assembleia Geral define as diretrizes para o funcionamento e as operações da cooperativa, e os sócios decidem sobre a forma de execução dos trabalhos, nos termos da lei.

Art. $3^{\mathrm{o}}$ A Cooperativa de Trabalho rege-se pelos seguintes princípios e valores:

I - adesão voluntária e livre; 
II - gestão democrática;

III - participação econômica dos membros;

IV - autonomia e independência;

V - educação, formação e informação;

VI - intercooperação;

VII - interesse pela comunidade;

VIII - preservação dos direitos sociais, do valor social do trabalho e da livre iniciativa;

IX - não precarização do trabalho;

$\mathrm{X}$ - respeito às decisões de asssembleia, observado o disposto nesta Lei;

XI - participação na gestão em todos os níveis de decisão de acordo com o previsto em lei e no Estatuto Social.

Art. 4ํㅜ A Cooperativa de Trabalho pode ser:

I - de produção, quando constituída por sócios que contribuem com trabalho para a produção em comum de bens e a cooperativa detém, a qualquer título, os meios de produção; e

II - de serviço, quando constituída por sócios para a prestação de serviços especializados a terceiros, sem a presença dos pressupostos da relação de emprego.

Parágrafo único. (VETADO).

Art. 5ำ A Cooperativa de Trabalho não pode ser utilizada para intermediação de mão de obra subordinada.

Parágrafo único. (VETADO).

Art. 6ํㅜ A Cooperativa de Trabalho poderá ser constituída com número mínimo de 7 (sete) sócios.

Art. $7^{0}$ A Cooperativa de Trabalho deve garantir aos sócios os seguintes direitos, além de outros que a Assembleia Geral venha a instituir:

I - retiradas não inferiores ao piso da categoria profissional e, na ausência deste, não inferiores ao salário mínimo, calculadas de forma proporcional às horas trabalhadas ou às atividades desenvolvidas; 
II - duração do trabalho normal não superior a 8 (oito) horas diárias e 44 (quarenta e quatro) horas semanais, exceto quando a atividade, por sua natureza, demandar a prestação de trabalho por meio de plantões ou escalas, facultada a compensação de horários;

III - repouso semanal remunerado, preferencialmente aos domingos;

IV - repouso anual remunerado;

V - retirada para o trabalho noturno superior à do diurno;

VI - adicional sobre a retirada para as atividades insalubres ou perigosas;

VII - seguro de acidente de trabalho.

$\S 1^{0}$ Não se aplica o disposto nos incisos III e IV do caput deste artigo nos casos em que as operações entre o sócio e a cooperativa sejam eventuais, salvo decisão assemblear em contrário.

$\S 2^{\circ}$ A Cooperativa de Trabalho buscará meios, inclusive mediante provisionamento de recursos, com base em critérios que devem ser aprovados em Assembleia Geral, para assegurar os direitos previstos nos incisos I, III, IV, V, VI e VII do caput deste artigo e outros que a Assembleia Geral venha a instituir.

$\S 3^{\text {o }}$ A Cooperativa de Trabalho, além dos fundos obrigatórios previstos em lei, poderá criar, em Assembleia Geral, outros fundos, inclusive rotativos, com recursos destinados a fins específicos, fixando o modo de formação, custeio, aplicação e liquidação.

\section{$\S 4^{\underline{0}}(\mathrm{VETADO})$.}

$\S 5$ 5 A Cooperativa de Trabalho constituída nos termos do inciso I do caput do art. $4^{\circ}$ desta Lei poderá, em Assembleia Geral Extraordinária, estabelecer carência na fruição dos direitos previstos nos incisos I e VII do caput deste artigo.

$\S 6^{-}$As atividades identificadas com o objeto social da Cooperativa de Trabalho prevista no inciso II do caput do art. 40 desta Lei, quando prestadas fora do estabelecimento da cooperativa, deverão ser submetidas a uma coordenação com mandato nunca superior a $1(\mathrm{um})$ ano ou ao prazo estipulado para a realização dessas atividades, eleita em reunião específica pelos sócios que se disponham a realizá-las, em que serão expostos os requisitos para sua consecução, os valores contratados e a retribuição pecuniária de cada sócio partícipe.

Art. 8 As Cooperativas de Trabalho devem observar as normas de saúde e segurança do trabalho previstas na legislação em vigor e em atos normativos expedidos pelas autoridades competentes.

Art. 9- $\mathrm{O}$ contratante da Cooperativa de Trabalho prevista no inciso II do caput do art. 4ํ desta Lei responde solidariamente pelo cumprimento das normas de saúde e segurança do trabalho quando os serviços forem prestados no seu estabelecimento ou em local por ele determinado. 


\section{CAPÍTULO II}

\section{DO FUNCIONAMENTO DAS COOPERATIVAS DE TRABALHO}

Art. 10. A Cooperativa de Trabalho poderá adotar por objeto social qualquer gênero de serviço, operação ou atividade, desde que previsto no seu Estatuto Social.

$\S 1^{0}$ É obrigatório o uso da expressão "Cooperativa de Trabalho" na denominação social da cooperativa.

$\S 2^{\circ}$ A Cooperativa de Trabalho não poderá ser impedida de participar de procedimentos de licitação pública que tenham por escopo os mesmos serviços, operações e atividades previstas em seu objeto social.

$\S 3^{\circ}$ A admissão de sócios na cooperativa estará limitada consoante as possibilidades de reunião, abrangência das operações, controle e prestação de serviços e congruente com o objeto estatuído.

$\S 4^{0}$ Para o cumprimento dos seus objetivos sociais, o sócio poderá exercer qualquer atividade da cooperativa, conforme deliberado em Assembleia Geral.

Art. 11. Além da realização da Assembleia Geral Ordinária e Extraordinária para deliberar nos termos dos e sobre os assuntos previstos na Lei $\mathrm{n}^{0} 5.764$, de 16 de dezembro de 1971, e no Estatuto Social, a Cooperativa de Trabalho deverá realizar anualmente, no mínimo, mais uma Assembleia Geral Especial para deliberar, entre outros assuntos especificados no edital de convocação, sobre gestão da cooperativa, disciplina, direitos e deveres dos sócios, planejamento e resultado econômico dos projetos e contratos firmados e organização do trabalho.

$\S 1^{\text {o }} \mathrm{O}$ destino das sobras líquidas ou o rateio dos prejuízos será decidido em Assembleia Geral Ordinária.

$\S 2^{\mathrm{o}}$ As Cooperativas de Trabalho deverão estabelecer, em Estatuto Social ou Regimento Interno, incentivos à participação efetiva dos sócios na Assembleia Geral e eventuais sanções em caso de ausências injustificadas.

§ 3ํㅜ O quorum mínimo de instalação das Assembleias Gerais será de:

I - 2/3 (dois terços) do número de sócios, em primeira convocação;

II - metade mais 1 (um) dos sócios, em segunda convocação;

III - 50 (cinquenta) sócios ou, no mínimo, 20\% (vinte por cento) do total de sócios, prevalecendo o menor número, em terceira convocação, exigida a presença de, no mínimo, 4 (quatro) sócios para as cooperativas que possuam até 19 (dezenove) sócios matriculados.

$\S 4^{0}$ As decisões das assembleias serão consideradas válidas quando contarem com a aprovação da maioria absoluta dos sócios presentes. 
$\S 5^{0}$ Comprovada fraude ou vício nas decisões das assembleias, serão elas nulas de pleno direito, aplicando-se, conforme o caso, a legislação civil e penal.

$\S 6^{0}$ A Assembleia Geral Especial de que trata este artigo deverá ser realizada no segundo semestre do ano.

Art. 12. A notificação dos sócios para participação das assembleias será pessoal e ocorrerá com antecedência mínima de 10 (dez) dias de sua realização.

$\S 1^{o}$ Na impossibilidade de notificação pessoal, a notificação dar-se-á por via postal, respeitada a antecedência prevista no caput deste artigo.

$\S 2^{\circ} \mathrm{Na}$ impossibilidade de realização das notificações pessoal e postal, os sócios serão notificados mediante edital afixado na sede e em outros locais previstos nos estatutos e publicado em jornal de grande circulação na região da sede da cooperativa ou na região onde ela exerça suas atividades, respeitada a antecedência prevista no caput deste artigo.

Art. 13. É vedado à Cooperativa de Trabalho distribuir verbas de qualquer natureza entre os sócios, exceto a retirada devida em razão do exercício de sua atividade como sócio ou retribuição por conta de reembolso de despesas comprovadamente realizadas em proveito da Cooperativa.

Art. 14. A Cooperativa de Trabalho deverá deliberar, anualmente, na Assembleia Geral Ordinária, sobre a adoção ou não de diferentes faixas de retirada dos sócios.

Parágrafo único. No caso de fixação de faixas de retirada, a diferença entre as de maior e as de menor valor deverá ser fixada na Assembleia.

Art. 15. O Conselho de Administração será composto por, no mínimo, 3 (três) sócios, eleitos pela Assembleia Geral, para um prazo de gestão não superior a 4 (quatro) anos, sendo obrigatória a renovação de, no mínimo, 1/3 (um terço) do colegiado, ressalvada a hipótese do art. 16 desta Lei.

Art. 16. A Cooperativa de Trabalho constituída por até 19 (dezenove) sócios poderá estabelecer, em Estatuto Social, composição para o Conselho de Administração e para o Conselho Fiscal distinta da prevista nesta Lei e no art. 56 da Lei $n^{\circ}$ 5.764, de 16 de dezembro de 1971, assegurados, no mínimo, 3 (três) conselheiros fiscais.

\section{CAPÍTULO III}

\section{DA FISCALIZAÇÃO E DAS PENALIDADES}

Art. 17. Cabe ao Ministério do Trabalho e Emprego, no âmbito de sua competência, a fiscalização do cumprimento do disposto nesta Lei.

$\S 1^{\mathrm{o}}$ A Cooperativa de Trabalho que intermediar mão de obra subordinada e os contratantes de seus serviços estarão sujeitos à multa de $\mathrm{R} \$ 500,00$ (quinhentos reais) por trabalhador prejudicado, dobrada na reincidência, a ser revertida em favor do Fundo de Amparo ao Trabalhador - FAT. 
$\S 2^{\underline{o}}$ Presumir-se-á intermediação de mão de obra subordinada a relação contratual estabelecida entre a empresa contratante e as Cooperativas de Trabalho que não cumprirem o disposto no $\S 6^{\circ}$ do art. $7^{\circ}$ desta Lei.

$\S 3^{\text {o }}$ As penalidades serão aplicadas pela autoridade competente do Ministério do Trabalho e Emprego, de acordo com o estabelecido no Título VII da Consolidação das Leis do Trabalho - CLT, aprovada pelo Decreto-Lei no 5.452 , de $1^{1}$ o de maio de 1943.

Art. 18. A constituição ou utilização de Cooperativa de Trabalho para fraudar deliberadamente a legislação trabalhista, previdenciária e o disposto nesta Lei acarretará aos responsáveis as sanções penais, cíveis e administrativas cabíveis, sem prejuízo da ação judicial visando à dissolução da Cooperativa.

\section{$\S 1^{\circ}$ (VETADO).}

$\S 2^{0}$ Fica inelegível para qualquer cargo em Cooperativa de Trabalho, pelo período de até 5 (cinco) anos, contado a partir da sentença transitada em julgado, o sócio, dirigente ou o administrador condenado pela prática das fraudes elencadas no caput deste artigo.

\section{CAPÍTULO IV}

\section{DO PROGRAMA NACIONAL DE FOMENTO ÀS COOPERATIVAS}

\section{DE TRABALHO - PRONACOOP}

Art. 19. É instituído, no âmbito do Ministério do Trabalho e Emprego, o Programa Nacional de Fomento às Cooperativas de Trabalho - PRONACOOP, com a finalidade de promover o desenvolvimento e a melhoria do desempenho econômico e social da Cooperativa de Trabalho.

Parágrafo único. O Pronacoop tem como finalidade apoiar:

I - a produção de diagnóstico e plano de desenvolvimento institucional para as Cooperativas de Trabalho dele participantes;

II - a realização de acompanhamento técnico visando ao fortalecimento financeiro, de gestão, de organização do processo produtivo ou de trabalho, bem como à qualificação dos recursos humanos;

III - a viabilização de linhas de crédito;

IV - o acesso a mercados e à comercialização da produção;

V - o fortalecimento institucional, a educação cooperativista e a constituição de cooperativas centrais, federações e confederações de cooperativas;

VI - outras ações que venham a ser definidas por seu Comitê Gestor no cumprimento da finalidade estabelecida no caput deste artigo.

Art. 20. É criado o Comitê Gestor do Pronacoop, com as seguintes atribuições: 
I - acompanhar a implementação das ações previstas nesta Lei;

II - estabelecer as diretrizes e metas para o Pronacoop;

III - definir as normas operacionais para o Pronacoop;

IV - propor o orçamento anual do Pronacoop;

$\mathrm{V}-($ VETADO)

$\mathrm{VI}-(\mathrm{VETADO})$.

$\S$ 1ํ O Comitê Gestor terá composição paritária entre o governo e entidades representativas do cooperativismo de trabalho.

$\S 2^{o}$ O número de membros, a organização e o funcionamento do Comitê Gestor serão estabelecidos em regulamento.

Art. 21. O Ministério do Trabalho e Emprego poderá celebrar convênios, acordos, ajustes e outros instrumentos que objetivem a cooperação técnico-científica com órgãos do setor público e entidades privadas sem fins lucrativos, no âmbito do Pronacoop.

Art. 22. As despesas decorrentes da implementação do Pronacoop correrão à conta das dotações orçamentárias consignadas anualmente ao Ministério do Trabalho e Emprego.

Art. 23. Os recursos destinados às linhas de crédito do Pronacoop serão provenientes:

I - do Fundo de Amparo ao Trabalhador - FAT;

II - de recursos orçamentários da União; e

III - de outros recursos que venham a ser alocados pelo poder público.

Parágrafo único. O Conselho Deliberativo do Fundo de Amparo ao Trabalhador CODEFAT definirá as diretrizes para a aplicação, no âmbito do Pronacoop, dos recursos oriundos do Fundo de Amparo ao Trabalhador - FAT.

Art. 24. As instituições financeiras autorizadas a operar com os recursos do Pronacoop poderão realizar operações de crédito destinadas a empreendimentos inscritos no Programa sem a exigência de garantias reais, que poderão ser substituídas por garantias alternativas, observadas as condições estabelecidas em regulamento.

Parágrafo único. (VETADO).

Art. 25. (VETADO).

CAPÍTULO V 


\section{DISPOSIÇÕES FINAIS}

Art. 26. É instituída a Relação Anual de Informações das Cooperativas de Trabalho RAICT, a ser preenchida pelas Cooperativas de Trabalho, anualmente, com informações relativas ao ano-base anterior.

Parágrafo único. O Poder Executivo regulamentará o modelo de formulário da RAICT, os critérios para entrega das informações e as responsabilidades institucionais sobre a coleta, processamento, acesso e divulgação das informações.

Art. 27. A Cooperativa de Trabalho constituída antes da vigência desta Lei terá prazo de 12 (doze) meses, contado de sua publicação, para adequar seus estatutos às disposições nela previstas.

Art. 28. A Cooperativa de Trabalho prevista no inciso II do caput do art. 4º desta Lei constituída antes da vigência desta Lei terá prazo de 12 (doze) meses, contado de sua publicação, para assegurar aos sócios as garantias previstas nos incisos I, IV, V, VI e VII do caput do art. $7^{\circ}$ desta Lei, conforme deliberado em Assembleia Geral.

Art. 29. Esta Lei entra em vigor na data de sua publicação.

Art. 30. (VETADO).

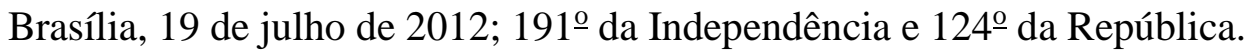

DILMA ROUSSEFF

José Eduardo Cardozo

Nelson Henrique Barbosa Filho

Carlos Daudt Brizola

Miriam Belchior

Luís Inácio Lucena Adams 


\section{FOTOS}

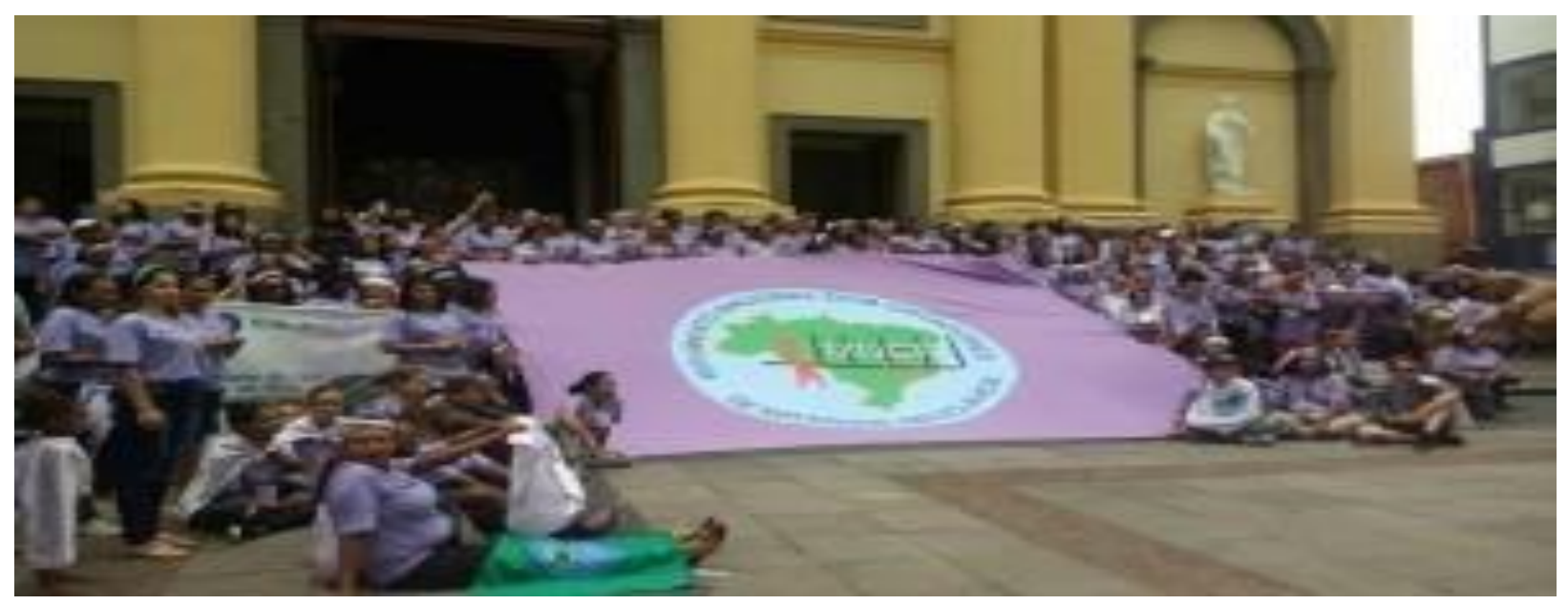

Fonte: http://www.ceadec.org.br/noticias/ii-congresso-estadual-da-mulher-catadora--sp

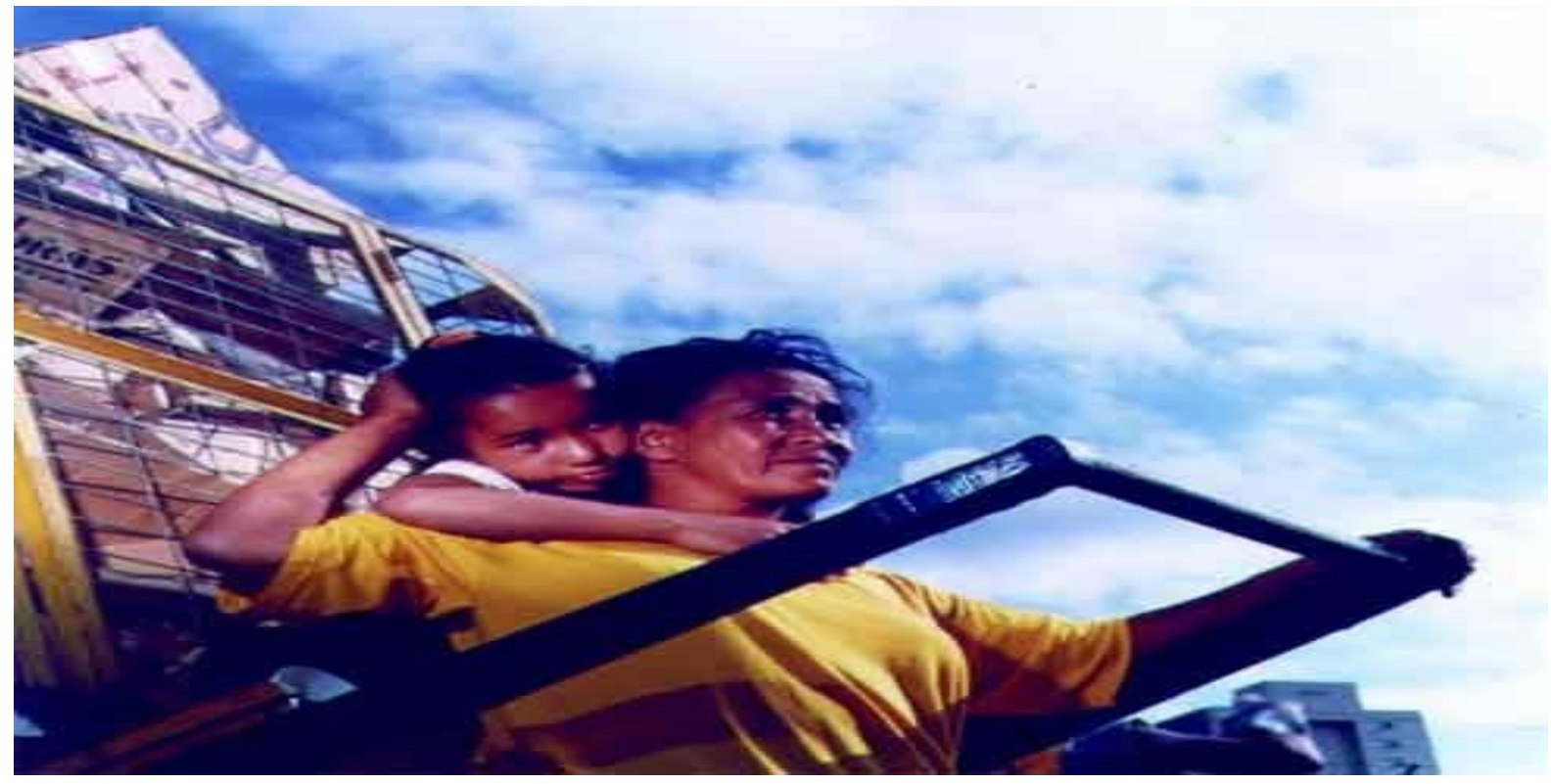

Fonte: http://www.mncr.org.br/multimidia/galeria-de-fotos/trabalho-de-catador

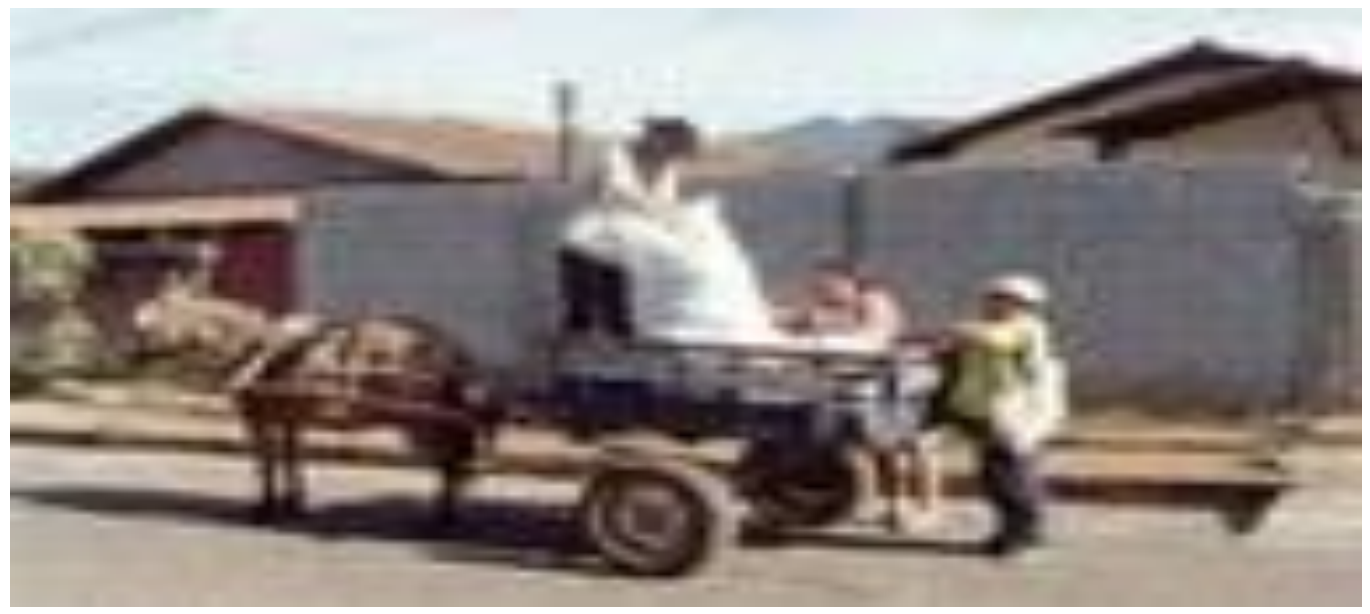


Fonte: http://www.mncr.org.br/multimidia/galeria-de-fotos/trabalho-de-catador

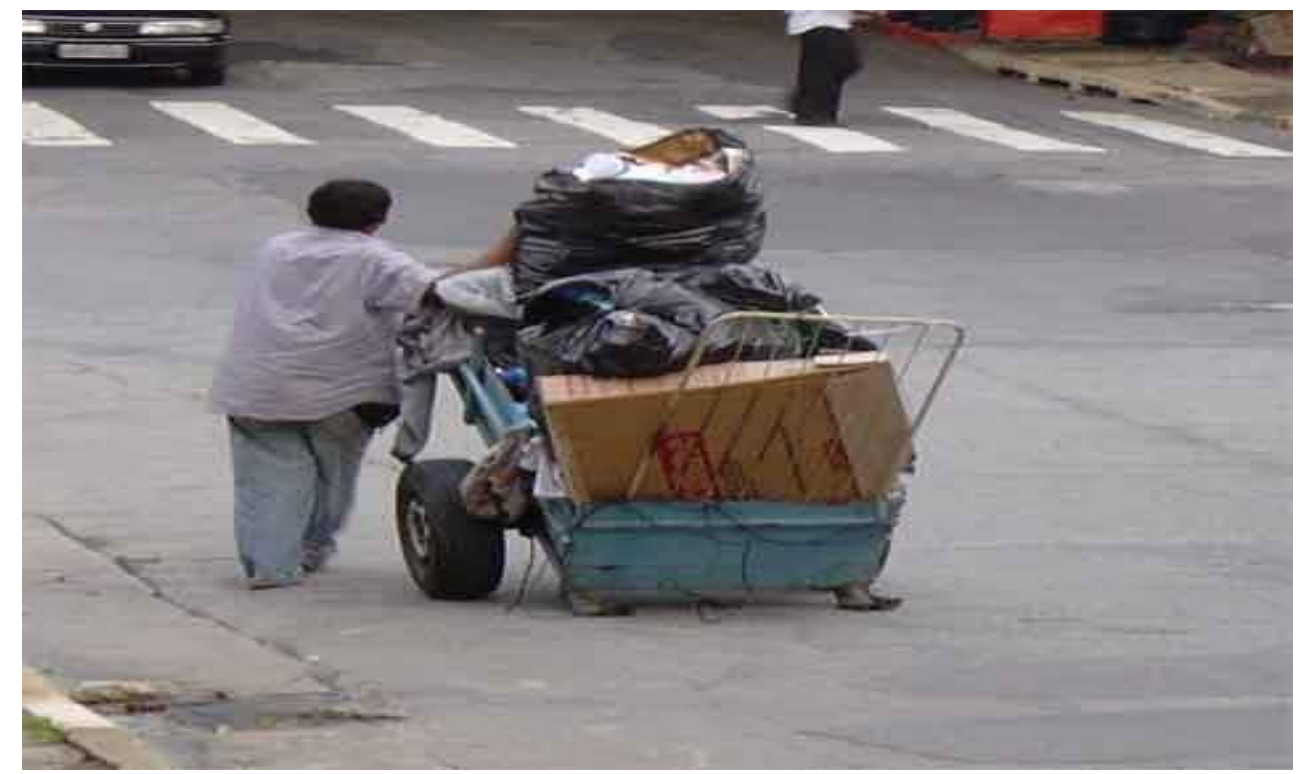

Fonte : http://www.mncr.org.br/multimidia/galeria-de-fotos/trabalho-de-catador 